\title{
WALTER SPINELLI
}

\section{A CONSTRUÇÃO DO CONHECIMENTO ENTRE O ABSTRAIR E O CONTEXTUALIZAR: O CASO DO ENSINO DA MATEMÁTICA}

Tese apresentada ao programa de pós-graduação da Faculdade de Educação da Universidade de São Paulo para obtenção do título de Doutor em Educação.

Área de concentração: Ensino de Ciências e Matemática

Orientador: Prof. Dr. Nilson José Machado

SÃo PAULO

2011 
Autorizo a reprodução e divulgação total ou parcial deste trabalho, por qualquer meio convencional ou eletrônico, para fins de estudo e pesquisa, desde que citada a fonte.

Catalogação na Publicação

Serviço de Biblioteca e Documentação

Faculdade de Educação da Universidade de São Paulo

$375.3 \quad$ Spinelli, Walter

S757c A construção do conhecimento entre o abstrair e o contextualizar : o caso do ensino da matemática / Walter Spinelli ; orientação Nilson José Machado. São Paulo : s.n., 2011.

$138 \mathrm{p}$ : il., tabs. grafs.

Tese (Doutorado - Programa de Pós-Graduação em Educação. Área de Concentração : Ensino de Ciências e Matemática ) - Faculdade de Educação da Universidade de São Paulo)

1. Matemática - Estudo e ensino 2. Abstração - Matemática 3. Concreto - Matemática 4. Significado - Matemática 5. Narrativa - Matemática 6. Metáfora - Matemática I.Machado, Nilson José, orient. 


\section{FOLHA DE APROVAÇÃO}

\section{Walter Spinelli}

A construção do conhecimento entre o

abstrair e o contextualizar: o caso do

ensino da Matemática

Tese apresentada à Faculdade de Educação da

Universidade de São Paulo para obtenção do título de Doutor em Educação.

Linha de pesquisa: Ensino de Ciências e Matemática.

Aprovada em:

\section{Banca examinadora}

Prof. Dr.

Instituição Assinatura

Prof. Dr.

Instituição Assinatura

Prof. Dr.

Instituição Assinatura

Prof. Dr.

Instituição Assinatura

Prof. Dr.

Instituição Assinatura 


\section{Agradecimentos}

Ao

Prof. Dr. Nilson José Machado,

por ter orientado com tanta gentileza e competência os rumos deste trabalho.

À companheira

Eliane Reame,

pela parceria de todos os momentos.

Aos amigos

Roberto Perides Moisés,

José Luiz Pastore Mello e

Carlos Eduardo De Souza Campos Granja,

pela convivência produtiva dos últimos tempos, responsável pela gestação de vários contextos de ensino.

À direção do

Colégio Móbile,

pela confiança depositada na viabilização de nossos projetos. 


\section{RESUMO}

SPINELLI, W. A construção do conhecimento entre o abstrair e o contextualizar: o caso do ensino da Matemática. 2011. 138 p. Tese (Doutorado) - Faculdade de Educação, Universidade de São Paulo, São Paulo, 2011.

Este trabalho analisa a importância que o desenvolvimento de conteúdos com base em contextos de ensino representa para a construção do conhecimento, especialmente o conhecimento matemático. O foco principal da reflexão pode ser traduzido na seguinte questão: $O$ que significa contextualizar o ensino, de modo geral, nas diversas etapas de educação e, mais especificamente, o que significa contextualizar o ensino da Matemática? As abstrações que o sujeito realiza desempenham importante papel na construção de qualquer conhecimento. Nesse processo, no âmbito educacional, os contextos de ensino são agentes que dão vida às abstrações, na medida em que configuram o objeto de estudo sobre uma rede de significações em que diversos conceitos se associam, permitindo, dessa forma, que o objeto do conhecimento seja visto como um feixe de relações, estabelecido a partir do conjunto de circunstâncias que caracteriza o contexto adotado. As abstrações, portanto, no que se refere à construção do conhecimento, não se constituem em ponto de partida e nem de chegada. Situam-se, pois, no estágio intermediário entre dois níveis de conhecimento concreto do objeto, favorecendo a ascensão de um a outro nível. Documentos oficiais publicados em décadas recentes apontam para a necessidade da contextualização do ensino. Os Parâmetros Curriculares Nacionais (PCN) e as diretrizes do Exame Nacional do Ensino Médio (ENEM) são, nesse sentido, emblemáticos, pois apresentam visões concordantes que orientam a contextualização do ensino para os universos do trabalho, da cidadania, da cultura, da tecnologia e da ciência, sob o foco, principalmente, da interdisciplinaridade. A efetivação de propostas dessa natureza passa pela composição de contextos com características diversas, voltadas para a interdisciplinaridade, para aplicações cotidianas dos conceitos, para a história da Matemática, dentre outros, sem relegar a segundo plano os contextos intradisciplinares, voltados para as relações internas à própria disciplina. $\mathrm{Na}$ composição de contextos de qualquer natureza revela-se a importância do papel do professor, como tecelão de percursos sobre a rede conceitual, organizando as narrativas convincentes para o transporte dos significados. O conhecimento que se constrói sob determinado contexto se universaliza quando são rompidas as invisíveis fronteiras desse contexto e outras relações de significado 
são construídas, em novos contextos. Assim, na construção do conhecimento, navegamos em um metafórico espaço de significações, que se caracteriza como um eixo em que a contextualização ocupa um dos extremos e a extrapolação dos contextos, o outro, de modo que a maior ou menor competência do sujeito é verificada por sua desenvoltura no percorrer de um a outro extremo desse eixo. É parco, portanto, o conhecimento que se constrói apenas sob os limites de determinado contexto e nele estaciona. O conjunto das referências teóricas utilizadas para a verificação da tese principal deste trabalho foi formado, principalmente, pelos escritos de Machado (2002, 2009), Goodman (1995) e Popper (2009). Os resultados da pesquisa permitem vislumbrar implicações e prolongamentos que poderão ser desenvolvidos em trabalhos futuros, conforme apontado na parte final do trabalho.

Palavras-chave: Matemática, ensino, contexto, abstração, contextualização, extrapolação, competência, redes, significado, narrativas, metáforas. 


\begin{abstract}
SPINELLI, W. Knowledge building amidst abstraction and contextualization: the case of Mathematics teaching. 2011. 138 p. Ph.D. Thesis - School of Education, University of São Paulo, São Paulo, 2011.
\end{abstract}

This study analyzes the development of content in contexts of teaching as an important factor leading to knowledge building. The following question sums up the main focus of this reflection: In general terms, what does contextualized teaching mean, in the several educational stages, and more specifically, what does contextualization mean in the teaching of Mathematics? Abstraction plays an important role in building any kind of knowledge. In this process, within the realm of education, teaching contexts are agents that bring abstraction to life, as they place the object of study on a signification network in which several concepts are associated. The object of knowledge is seen as a web of relations, based on the circumstances defining such context. Thus, as far as knowledge building is concerned, abstraction is neither the starting point nor the end of the process. It lies rather in an intermediate stage between two levels of concrete knowledge of the object, bridging the gap between one level and the other. Official documents recently published have highlighted the need for contextualized teaching. Among them, the National Curriculum Parameters $(P C N)$ and the guidelines for the National High School Examination (ENEM) present concurring views that reinforce such trend and guide the contextualization of teaching towards the realm of labor, citizenship, culture, technology and science, with an interdisciplinary approach. The implementation of such proposals relies on the composition of contexts with several different characteristics, related to interdisciplinary issues, to the application of concepts in everyday life, to the history of Mathematics, among others, without neglecting the intradisciplinary contexts, which bear the internal relations of the discipline itself. While composing any kind of context, teachers play an essential role in weaving student's ways through the conceptual network, organizing convincing narratives for the transport of meaning. Knowledge which is built within a given context becomes universal as the invisible boundaries of such context are removed and other relations of meaning are built, in new contexts. This way, building knowledge involves traveling a metaphorical space of signification, which can be described as an axis having contextualization as one of its extremes and extrapolation of context as the other. The knowledge building competence of the subject is related to his or her performance 
while moving along this axis, from one extreme to the other. Therefore, limited is the knowledge which is built and kept within the boundaries of a single context. The array of theoretical references supporting the main thesis of this research work includes, among others, the works of Machado (2002, 2009), Goodman (1995) and Popper (2009). The results of this study point to implications and issues that may be explored in further research, as seen in the final part of this thesis.

Key words: Mathematics, teaching, context, abstraction, contextualization, extrapolation, competence, networks, meaning, narratives, metaphors. 


\section{RESUMEN}

SPINELLI, W. La construcción del conocimiento entre la abstracción y la contextualización: el caso de la enseñanza de la Matemática. 2011. 138 p. Tesis (Doctorado) - Facultad de Educación, Universidad de San Pablo, San Pablo, 2011.

Este trabajo analiza la importancia que el desarrollo de contenidos basados en contextos de enseñanza representa para la construcción del conocimiento, especialmente del conocimiento matemático. Se puede traducir el foco principal de la reflexión en la siguiente pregunta: ¿Qué significa contextualizar la enseñanza, de un modo general, en las diversas etapas de educación y más específicamente, qué significa contextualizar la enseñanza de la Matemática? Las abstracciones realizadas por el sujeto desempeñan un papel importante en la construcción de cualquier conocimiento. En este proceso, en el ámbito educativo, los contextos de enseñanza son agentes que dan vida a las abstracciones, en la medida en que configuran el objeto de estudio sobre una red de significaciones a las que se asocian diversos conceptos, y permiten, de esta manera, que el objeto de conocimiento sea visto como un grupo de relaciones, establecido a partir del conjunto de circunstancias que caracteriza el contexto adoptado. Por lo tanto, en lo que se refiere a la construcción del conocimiento, las abstracciones no se constituyen en punto de partida ni de llegada. Se sitúan, pues, en una etapa intermediaria entre dos niveles de conocimiento concreto del objeto y favorecen el ascenso de un nivel al otro. Documentos oficiales publicados en décadas recientes señalan la necesidad de una contextualización de la enseñanza. Los Parámetros Curriculares Nacionales (PCN) y las directrices del Examen Nacional de la Enseñanza Media (ENEM) son, en este sentido, emblemáticos, ya que presentan visiones concordantes que orientan la contextualización de la enseñanza hacia los universos del trabajo, de la ciudadanía, la cultura, la tecnología y la ciencia, bajo el foco, principalmente, de la interdisciplinariedad. La concresión de propuestas de esta naturaleza pasa por la composición de contextos con características diversas, orientadas a la interdisciplinariedad, a las aplicaciones cotidianas de los conceptos, a la historia de la matemática, entre otros, sin relegar a un segundo plano los contextos interdisciplinarios, que se orientan hacia las relaciones internas de la propia disciplina. En la composición de contextos de cualquier naturaleza se revela la importancia del papel del profesor, como un arquitecto de trayectos sobre la red conceptual y como organizador de narrativas convincentes que puedan transportar significados. El conocimiento 
que se construye bajo un determinado contexto se universaliza cuando se rompen las invisibles fronteras de ese contexto y se construyen otras relaciones de significado en nuevos contextos. De esta manera, en la construcción del conocimiento, navegamos en un metafórico espacio de significaciones, que se caracteriza como un eje en el que la contextualización ocupa uno de los extremos y la extrapolación de los contextos el otro, de modo que la mayor o menor competencia del sujeto se verifica por su desenvoltura en el recorrido de uno al otro extremo de ese eje. Por lo tanto, es escaso el conocimiento que se construye solamente bajo los límites de un determinado contexto y que en él se detiene. El conjunto de las referencias teóricas utilizadas para la verificación de la tesis principal de este trabajo, está formado, principalmente, por los escritos de Machado (2002, 2009), Goodman (1995) y Popper (2009). Los resultados de la investigación permiten vislumbrar implicaciones y prolongaciones que podrán ser desarrolladas en trabajos futuros, conforme apuntamos en la parte final del trabajo.

Palabras clave: Matemática, enseñanza, contexto, abstracción, contextualización, extrapolación, competencia, redes, significado, narrativas, metáforas. 


\section{SUMÁRIO}

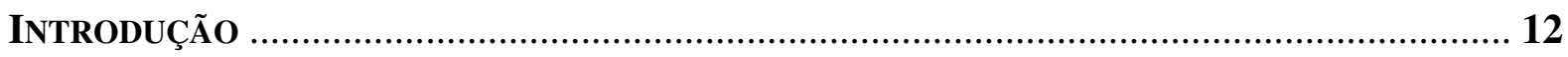

CAPÍTULO 1 - AS ABSTRAÇÕES E OS SIGNIFICADOS DOS OBJETOS.......................................... 18



1.2. AS ABSTRAÇÕES E O CONHECIMENTO TEÓRICO........................................................... 19

CAPÍTULO 2 - A POLISSEMIA DO CONTEXTO................................................................... 28



2.2. ENSINO E CONTEXTUALIZAÇÃO: CONCEPÇÕES E EQUÍVOCOS............................................ 29

2.3. O EXame Nacional do Ensino Médio (ENEM) e os Parâmetros

CURRICULARES NACIONAIS (PCNS) ...................................................................... 33

CAPÍTULO 3 - A CRIAÇÃo de ConTEXTOS DE ENSINO............................................................ 45



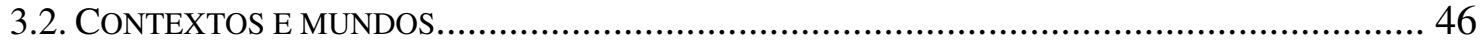

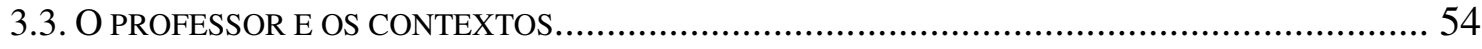

3.3.1. COMPETÊNCIAS DISCENTES...................................................................... 56

3.3.2. COMPETÊNCIAS DOCENTES.................................................................... 58

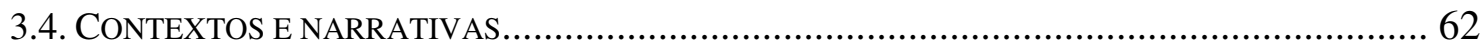

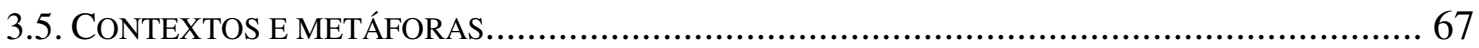

CAPítulo 4 - ConTEXTOS Significativos: o CaSO da Matemática................................... 75

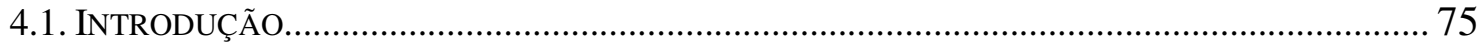

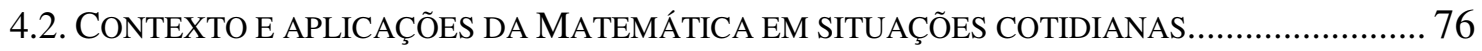

4.2.1. UM EXEMPLO DE CONTEXTO DE ENSINO VOLTADO PARA APLICAÇÕES COTIDIANAS: AS MATRIZES........................................................................... 77

4.2.2. OUTRO EXEMPLO DE CONTEXTO DE ENSINO VOLTADO PARA APLICAÇÕES COTIDIANAS: A TRIGONOMETRIA................................................................... 87

4.3. CONTEXTO E INTERDISCIPLINARIDADE PARA O ENSINO DE MATEMÁTICA..............................90

4.3.1. UM EXEMPLO DE CONTEXTO DE ENSINO VOLTADO PARA A INTERDISCIPLINARIDADE: O FENÔMENO DAS MARÉS............................................ 92

4.4. O CONTEXTO E A HISTÓRIA DA MATEMÁTICA NO ENSINO DA MATEMÁTICA.......................... 97

4.4.1. UM EXEMPLO DE CONTEXTO DE ENSINO ELABORADO A PARTIR DE ELEMENTOS DA HISTÓRIA DA MATEMÁTICA: A CONSTRUÇ̃̃o DOS NÚMEROS REAIS................101

4.5. CONTEXTO E INTRADISCIPLINARIDADE NO ENSINO DA MATEMÁTICA - E ALGO SOBRE A TRANSDISCIPLINARIDADE. 104

4.5.1. UM EXEMPLO DE CONTEXTO INTRAMATEMÁTICO DE ENSINO:

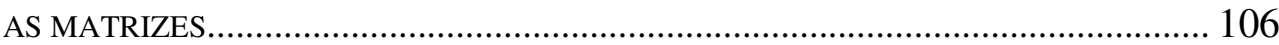

4.5.2. OUTRO EXEMPLO DE CONTEXTO INTRAMATEMÁTICO DE ENSINO:



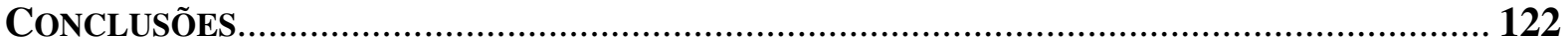

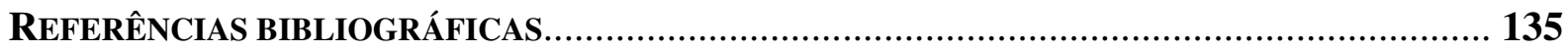




\section{INTRODUÇÃO}

Os estudos realizados nesta pesquisa, cujos resultados apresentamos em seguida, foram motivados por dúvidas resultantes de nossa atuação de tantos anos como professor de Ensino Fundamental e Médio. As preocupações iniciais surgidas em salas de aula, quanto à possibilidade de assegurar aos alunos interpretações suficientemente abrangentes para os conhecimentos matemáticos que construíam, pouco a pouco tomaram corpo e nos impuseram o desafio do estudo e da pesquisa acerca de aspectos epistemológicos, com o objetivo de, por um lado, buscar fundamentação teórica para a prática que já realizávamos e, por outro lado, apontar aspectos orientadores para uma revisão constante dessa prática.

A falta de motivação dos alunos pelo aprendizado matemático é gerada por razões múltiplas, que partem de precárias condições físicas de espaços escolares e caminham até a carência na formação dos profissionais de ensino. Indo além desses sintomas conhecidos de nossa realidade, considerando, portanto, situação escolar próxima do ideal, nos preocupamos em compreender os motivos que impelem muitos alunos a enxergarem o conhecimento matemático como algo totalmente desprovido de significados, de qualquer natureza. Nessa procura, nos deparamos com a ausência de planejamentos pedagógicos que considerassem as possíveis aproximações entre significados construídos e por serem construídos, de maneira que pudessem ser aproveitadas as prototeias de relações conceituais que caracterizam os conhecimentos prévios dos alunos.

A ação do sujeito de aproximar significados em construção dos que já construiu denota a importância dos âmbitos de ensino em que as relações de aproximação são estimuladas. Em outros termos, engrossamos o coro das vozes que discutem sobre a necessidade de contextualizar, ou de contextuar, o ensino da Matemática. A partir disso, sentimos que seria necessário avaliar toda a gama de aspectos que envolvem a questão da contextualização do ensino, quer fossem de natureza metodológica de como os conceitos são apresentados aos alunos, ou de natureza epistemológica, acerca da maneira como os sujeitos constroem seu conhecimento matemático. Em vista disto, chegamos à questão norteadora da pesquisa:

O que significa contextualizar o ensino, de modo geral, nas diversas etapas de educação e, mais especificamente, o que significa contextualizar o ensino da Matemática? 
A ideia da contextualização do ensino da Matemática está, no senso comum, direta e unicamente associada à aplicação dos conceitos em situações cotidianas. Esta é, de fato, uma das possíveis formas de estimular a atribuição de significados aos objetos de estudo, mas não é a única e nem sempre é a mais importante. Compreender que o conhecimento exige ser construído com base nas relações estimuladas por múltiplos contextos, com diferentes características, foi um dos principais desafios de nosso estudo.

As características da contextualização do ensino, especialmente no caso da Matemática, estão vinculadas às concepções de como o sujeito constrói seu conhecimento. Quando se acredita que a apresentação dos conteúdos matemáticos deve ocorrer com base na gradação da dificuldade que intrinsecamente apresentam, isto é, do simples ao complexo, têmse no horizonte determinada possibilidade de contextualização, caracterizada pela ultrapassagem de um a outro nível de compreensão. Ou seja, o desafio de galgar um a um os degraus formados pela dificuldade crescente é, nesse caso, o elemento estruturador do contexto de ensino. Quando, sob outra perspectiva, se acredita que o sujeito constrói seu conhecimento quando estabelece relações entre diferentes significados conceituais, formando uma espécie de rede na qual os significados se enredam, se aproximam, a partir de múltiplas características que ora se interceptam e ora se complementam, vislumbram-se diversificadas maneiras de compor o contexto de ensino. Nesse caso, diversificam-se as circunstâncias estruturadoras dos contextos.

As respostas que obtivemos à questão principal do trabalho foram construídas a partir da concepção epistemológica de que o sujeito constrói seu conhecimento quando relaciona diversos significados conceituais, uns com os outros, compondo, dessa forma, uma rede de significados. Trata-se da metáfora da rede de significados como imagem associada à construção do conhecimento, conforme abordamos no capítulo 1.

Compactuando com a posição dos que afirmam que "sem abstração não há conhecimento" (Machado, 2009, p. 43), vislumbramos a necessidade, neste trabalho, de analisar o papel que os contextos de ensino representam no estímulo às abstrações. Para tanto, foi necessário interpretar a presença dos contextos nas relações entre ações de abstrair e de concretizar, com o objetivo de, primeiramente, compreender a direção e o sentido destes movimentos do pensar humano e, em segundo lugar, lançar a hipótese de que a construção do conhecimento não pode situar-se imersa nos limites estabelecidos por um único contexto. 
A análise dos movimentos do pensar humano, entre o concretizar e o abstrair, e as considerações acerca da concepção do conhecimento que se constrói com base na metáfora da rede de significados formaram o primeiro componente teórico deste trabalho e foram tratados no Capítulo 1 - As abstrações e os significados dos objetos.

A discussão acerca da contextualização do ensino, não apenas de Matemática, está presente há algum tempo em propostas curriculares de variadas instâncias. Analisar as características dos prováveis contextos de ensino constitui-se, a nosso ver, em importante aspecto de sustentação às considerações teóricas. Nesse sentido, no Capítulo 2 - A polissemia do contexto, descrevemos os resultados de nosso estudo acerca de como a ideia de contexto é apresentada em documentos oficiais, especialmente nos Parâmetros Curriculares Nacionais (PCNs) para o Ensino Médio.

De modo análogo, avaliações institucionais, oficiais ou não, têm sido produzidas com o foco apontado em questões com enunciados orientados para a contextualização. Nesse sentido, o caso do Exame Nacional do Ensino Médio (ENEM) é emblemático, na medida em que surge com a proposição clara de avaliar os alunos quanto à mobilização de conjunto determinado de habilidades, a partir do enfrentamento de questões elaboradas sob diferentes contextos. Pareceu-nos importante analisar as características de algumas questões propostas pelo ENEM, comparando-as com os aspectos balizadores da proposta geral deste exame, conforme descrevemos no Capítulo 2 acreditando que tal estudo nos permitiria, como de fato ocorreu, detectar elementos concordantes ou discordantes em relação aos pressupostos apresentados nos documentos que analisamos.

No Capítulo 3 - A criação de contextos de ensino, apresentamos o segundo componente teórico de sustentação na verificação de nossa tese. Contextos de ensino são compostos por conjuntos de circunstâncias - ideias, fatos, personagens, fenômenos etc. - que se inter-relacionam e estruturam um campo fértil para a identificação de significados conceituais. Para compreender a maior ou menor eficácia de contextos de ensino com tais características, no que diz respeito ao envolvimento dos alunos com os conteúdos apresentados, buscamos elementos teóricos que pudessem contribuir para a compreensão dos aspectos importantes a serem respeitados na composição contextual. Encontramos especialmente nas obras de três autores, Goodman (1995), Popper (2009) e Machado (2002 e 2009), as respostas que buscávamos e que descreveremos brevemente em sequência, dando a elas o espaço necessário no Capítulo 3. 
Goodman (1995), discorrendo sobre a posição relativista segundo a qual a constituição das verdades depende da formação intelectual do indivíduo ou dos grupos de indivíduos, aponta cinco aspectos de um universo de significações que intitulou feitura de mundos, que incorporamos e transpusemos para a composição de contextos de ensino. Estes são os aspectos que analisamos e relacionamos a exemplos de composições de contextos: Composição e decomposição, Enfatização, Ordenação, Supressão e completação, $e$ Deformação.

As posições relativistas de Goodman (1995) são combatidas por Popper (2009) em virtude do que denominou Mito do contexto. Sem o aprofundamento que outro trabalho poderia dedicar ao tema da controvérsia entre relativistas e racionalistas, nos apropriamos, no Capítulo 3, das ideias de Popper (2009) a respeito da conceituação de contexto e da necessidade de se romper as barreiras contextuais em busca de um almejado consenso no campo da ciência e das relações sociais.

Machado (2009) destaca as competências a serem desenvolvidas pelos alunos, isto é, a capacidade de "mobilizar o que se sabe para realizar o que se deseja" (p. 260). Em seu trabalho, Machado organiza o conjunto de seis competências sobre três eixos com duas competências complementares em cada um deles. Em um dos eixos, o autor destaca a Expressão e a Compreensão, em outro, a Argumentação e a Decisão, e no último, a Contextuação e a Imaginação. Em nossa análise, avaliamos a importância dos alunos transitarem sobre esse terceiro eixo, com extremos nos atos de contextuar e de imaginar, uma vez que é nesse trânsito que se embute um dos aspectos principais de nossa tese, qual seja, que a construção do conhecimento não pode situar-se imersa nos limites estabelecidos por um único contexto.

Também no Capítulo 3 analisamos as competências identificadas por Machado (2009) como fundamentais para o professor em sua função, relacionando-as aos aspectos destacados por Goodman (1995) a respeito da composição de contextos. Os escritos de Machado (2009) formaram, portanto, o pilar principal que nos permitiu transpor para o âmbito educacional os cinco aspectos apontados por Goodman (1995).

O conjunto de circunstâncias que caracterizam um contexto de ensino necessita do traçado de percursos capazes de relacionar diversos significados e de transportá-los de modo efetivo até os alunos. Nessa tarefa, denota-se a importância maior da composição de narrativas e da utilização de metáforas. 
Contextos e narrativas apresentam entre si relação quase simbiótica, de maneira que contextos de ensino sempre surgem acompanhados de narrativas apropriadas, enquanto as ideias presentes nas narrativas conduzem o pensamento do sujeito para aspectos de algum contexto. Dessa forma, narrativas são estruturadas pelos contextos e, simultaneamente, configuram-se em elementos que os estruturam, conforme abordaremos no Capítulo 3, encerrando, assim, a configuração teórica que elaboramos para justificar a tese principal deste trabalho.

As considerações teóricas realizadas nos Capítulos 1 e 3, bem como as referências obtidas nos documentos e avaliações oficiais destacadas no Capítulo 2 serão revisitadas durante a apresentação dos exemplos de contextos que elaboramos para o ensino de conteúdos matemáticos, no Capítulo 4 - Contextos significativos: o caso da Matemática.

Nesse capítulo destacamos exemplos de contextos de ensino identificados por conjuntos determinados de características. O primeiro exemplo de contexto de ensino trata do conteúdo Matrizes, e foi composto a partir da aplicabilidade dos conceitos em situações cotidianas que, neste caso, consistiu na construção e na representação de imagens por intermédio de comandos binários, especialmente em dois casos: princípio da tomografia e pixels.

O segundo exemplo de contexto foi composto com base em relações interdisciplinares, notadamente entre a Matemática e a Física, e aborda conceitos de Trigonometria a partir do estudo da periodicidade envolvida no fenômeno das marés.

O recurso à História da Matemática foi o elemento motivador da composição do contexto do terceiro exemplo destacado no Capítulo 4. Nesse caso, abordamos a evolução dos conjuntos numéricos e a construção do campo Real, retomando e transpondo para nossa realidade ideias e eventos recuperados da história dos gregos antigos, com o objetivo da construção da reta numérica.

Vastas e férteis são as relações entre significados conceituais internamente à própria Matemática. Qualquer elemento de conteúdo matemático em que pensarmos poderá ser facilmente relacionado a outro, e a outro, e a outro etc. Apenas como exemplo, se considerarmos as sequências numéricas, imediatamente poderemos relacioná-las ao crescimento exponencial, ao cálculo de juros, aos logaritmos, às séries, à representação de padrões geométricos etc. A qualidade dessas relações, que se configura em uma das características do conhecimento matemático, estimula a composição de contextos de ensino, 
contextos estes que denominamos contextos intramatemáticos. Em nosso exemplo, abordamos conteúdo de Ensino Médio bastante emblemático no que tange à dificuldade de vê-lo em aplicações cotidianas ou mesmo em relações interdisciplinares. Por outro lado, tal conteúdo apresenta inúmeras relações com outros blocos de conteúdos matemáticos, como por exemplo, as matrizes, a trigonometria e a geometria analítica. Tratam-se dos números complexos, analisados no exemplo em sua função de gerenciadores de transformações no plano.

Em síntese, no Capítulo 4 abordamos quatro situações de contextos de ensino: contexto e aplicações cotidianas, contexto e história da Matemática, contexto e interdisciplinaridade e contexto e intradisciplinaridade. Para esses casos descrevemos, além dos exemplos aplicados em sala de aula, suas principais características à luz dos elementos teóricos estudados e apresentados nos capítulos anteriores.

Como afirmamos, valorizamos a importância da contextualização do ensino de modo geral, muito embora a leitura dos capítulos deste trabalho mostrará que nos detivemos mais atentamente na contextualização do ensino da Matemática. Entendemos que a ênfase atribuída ao ensino contextualizado encontra justificativa na importância dos contextos de ensino no que concerne ao estímulo às abstrações. Todavia, devemos evitar o exagero da contextualização, no sentido de não limitar a identificação de relações entre significados conceituais cuja vivência ocorre além do contexto adotado. Ou seja, a construção conceitual alia-se fortemente à existência de um âmbito, no qual é permitido ao sujeito reconhecer as relações existentes entre os elementos do conjunto de circunstâncias que estrutura tal contexto, mas, alia-se também, à necessidade da extrapolação dos âmbitos, a fim de que sejam percebidas outras relações, em outros contextos. Este aspecto, cuja fundamentação teórica nos colocou em contato com os textos, principalmente os de Machado (2009) e Popper (2009), compõe o quadro das Conclusões de nosso trabalho.

Finalmente, apresentamos os principais elementos que percebemos e organizamos no sentido de responder à nossa preocupação acerca da contextualização do ensino da Matemática, e indicamos os desdobramentos que vislumbramos como continuidade aos estudos, sugerindo novas perguntas e novos caminhos de pesquisa. 


\title{
CAPÍTUlO 1 - AS ABSTRAÇÕES E OS SIGNIFICADOS DOS OBJETOS
}

\author{
[....] grande parte de nosso conhecimento não se relaciona \\ diretamente com as coisas e sim apenas com os pontos de vista \\ a respeito delas. (Tung-Sun)
}

\subsection{INTRODUÇÃO}

Para analisar a importância que contextos de ensino representam na aprendizagem de conteúdos matemáticos, objetivo primeiro deste trabalho, julgamos ser necessário apresentar e analisar alguns elementos teóricos capazes de fornecer sustentação às considerações posteriores e aos exemplos que serão discutidos. Dois aspectos, nesse sentido, merecerão nossa atenção neste Capítulo 1.

No primeiro aspecto, teceremos comentários acerca de como compreendemos a construção do conhecimento, recorrendo especialmente à concepção de que o conhecimento é construído com base no modelo da rede de significados e aos estudos de Machado (2002). Aceitas as premissas desse modelo que, como afirmamos, é um dos pilares que estruturam nossa tese, passaremos, em seguida, à abordagem do segundo aspecto, qual seja, a análise daquilo que Henri Lefebvre denominou "movimentos do pensar", isto é, a relação dialética entre o abstrair e o concretizar.

Opiniões de professores de diferentes segmentos de ensino apontam para diferentes sentidos dos "movimentos do pensar". Se, para alguns professores, o pensamento do sujeito durante a construção conceitual parece partir do concreto em direção ao abstrato, para outros, o sentido parece inverter-se, com a construção conceitual partindo das abstrações em direção à concretude das aplicações cotidianas.

A partir das posições sobre os sentidos do movimento do pensar, recolhidas de teóricos como Machado (2002), Tung-Sun (2000), Rambaldi (1988), dentre outros, apresentaremos os elementos que poderão compor a estrutura teórica que julgamos necessária. 


\subsection{AS ABSTRAÇÕES E O CONHECIMENTO TEÓRICO}

As múltiplas relações estabelecidas entre os elementos de nosso cotidiano contribuem, mais do que em outros tempos, para a concepção de que o ato de conhecer um objeto implica em vê-lo relacionado a outros, com significados diversos e que de alguma forma se aproximam. Visto dessa forma, um objeto pode ser compreendido como um feixe de relações, relações estas que dependem, em quantidade e em qualidade, do grau de conhecimento que o sujeito possui sobre ele. No processo de construção conceitual, novos significados são agregados, ampliando o feixe de relações e constituindo uma espécie de rede, um emaranhado de significações em torno do objeto.

O conhecimento de algum objeto é construído, portanto, a partir das relações que o sujeito estabelece entre seus diversos significados conceituais. A quantidade e a qualidade dessas relações graduam o nível de compreensão acerca do objeto de conhecimento. Assim, conhecer é conhecer os significados e vê-los em suas múltiplas relações. Tal observação, que associa o ato de conhecer à elaboração de uma espécie de rede conceitual, caracteriza o pilar primordial de sustentação de nossa tese. O modelo da construção do conhecimento com base na metáfora da rede de significados torna-se apropriado para a compreensão dessa trama de relações que se estabelece entre diferentes significados de um objeto. Justifica-se, portanto, destacar os pressupostos de tal modelo, recolhidos de Machado (2002):

- compreender é apreender o significado;

- apreender o significado de um objeto ou de um acontecimento é vê-lo em suas relações com outros objetos ou acontecimentos;

- os significados constituem, pois, feixes de relações;

- as relações entretecem-se, articulam-se em teias, em redes, constituídas social e individualmente, e em permanente estado de atualização;

- em ambos os níveis - individual e social - a ideia de conhecer assemelha-se à de enredar. (p. 138)

A concepção de que o sujeito constrói o conhecimento acerca de algum objeto a partir do estabelecimento de múltiplas relações entre os significados conceituais desse objeto, se contrapõe à clássica visão do encadeamento cartesiano, segundo o qual a apresentação dos conteúdos é organizada com base em relações conceituais que partem do simples e caminham 
em direção ao complexo. Assim, o objeto de estudo é decomposto em partes ordenadas com base numa estimada dificuldade de compreensão de cada uma. À medida que as partes são estudadas, estas passam a compor, pouco a pouco, o conhecimento sobre o objeto.

Há, dessa maneira, diferença fundamental entre uma e outra concepção acerca de como o conhecimento se constrói, que pode ser percebida a partir das disposições geométricas que, metaforicamente, podemos associar a cada uma, por um lado uma rede e, por outro, uma corrente. Enquanto uma rede permite visualizarmos o objeto do conhecimento envolto por múltiplas relações, que se estabelecem a partir dos diversos significados conceituais, um encadeamento, nos moldes cartesianos, apresenta o conceito dissecado em várias partes que se alinham com base na dificuldade de cada uma, de modo que o nível de complexidade regule a ordenação das partes na composição final do conceito.

O desenvolvimento de conteúdos matemáticos a partir de conjuntos de circunstâncias componentes de determinado âmbito caracteriza a adoção de contextos de ensino, conforme trataremos de justificar adiante. Por ora, destacamos que a adoção de contextos de ensino é ação tributária da concepção de que o conhecimento se constrói com base na metáfora da rede de significados. Vale ressaltar, entretanto, que o respeito às características dos elementos desses conjuntos de circunstâncias, que associaremos ao ato de contextualizar e justificaremos adiante, impõe obediência a determinado percurso, exigindo o traçado de um caminho sobre a rede conceitual. Em outras palavras, será necessário formular determinados encadeamentos conceituais a fim de que o contexto escolhido possa embasar o desenvolvimento dos conteúdos. Assim, como afirma Machado:

Ao organizar as tarefas docentes, ao planejar um curso, um professor arquiteta um percurso sobre essa imensa teia; e sem sombra de dúvida, precisa ordenar os passos a serem dados, quase sempre linearmente, encadeando significações. (2009, p. 63)

A variedade de significados conceituais organiza-se sobre os nós dessa imensa teia, de modo que, ao percorrê-la em acordo com um percurso predeterminado e em função da seleção dos elementos característicos do contexto, estabelecemos relações entre os diversos nós/significados, construindo, assim, nosso conhecimento acerca de algum objeto. Não há, todavia, um percurso conceitual único a ser percorrido, da mesma forma que não podemos imaginar a existência de apenas um modelo de contextualização dos conceitos a serem ensinados. Há entre contextos e percursos sobre a teia de significados uma relação simbiótica, 
que se verifica na medida em que são elaborados roteiros norteadores dos encadeamentos previstos, embora não exista, entre contexto e percurso, correspondência biunívoca, ou seja, podemos construir vários percursos a partir de um mesmo contexto. A riqueza e a eficiência desses percursos relacionam-se diretamente à maneira como estimulam relações entre os significados conceituais. Nesse sentido, como comentaremos em capítulo adiante, o papel do professor na constituição de narrativas é de fundamental importância.

Na construção dos significados do objeto pelo sujeito, o papel das abstrações que este realiza é preponderante. Isto porque um significado sempre se traduz por intermédio de um signo, de algo que permita ao sujeito, quando solicitado, recorrer a imagens mentais que rapidamente tragam à tona as características do objeto de interesse no momento. Trata-se, portanto de justificar a ação estruturadora que as abstrações realizam no sentido da construção conceitual. Para tanto, torna-se necessário analisar o papel das abstrações em conjunto com a ação que o senso comum coloca em completa oposição a elas, ou seja, em conjunto com o ato de concretizar. Abstrair e concretizar são ações presentes na construção do conhecimento e, para entender a importância que a escolha de contextos de ensino desempenha nesse processo, convém refletir sobre os movimentos que ocorrem entre estas ações.

Diferentes significados são atribuídos, cotidianamente, aos termos "concreto" e "abstrato". Para muitos, em contextos delimitados, "concreto" é aquilo que se pode tocar, pesar, provar, moldar, enquanto "abstrato" está ligado a conceitos, reflexões, projeções, e idealizações.

Nessa perspectiva, concreto representa aquilo que é palpável e que, por isso mesmo, pode ser associado a um significado imediato. Uma laranja é um objeto concreto com significados claramente identificados - é fruta cítrica, tem suco, é esférica etc. - assim como também são concretos uma tesoura, um sapato ou uma caneta.

Em relação ao objeto abstrato, aquilo que, para o senso comum, o distingue do concreto, é o fato de ser concebido de forma artificial, e de existir apenas no plano das ideias. Se em primeira instância, é abstrato aquilo que não se pode tocar, parece possível atribuir-se ao objeto abstrato a ausência de significados "concretos". Assim, na imagem cotidiana, é abstrato aquilo que não conheço, que sequer sei do que se trata, onde existe, em que se aplica etc.

Nessa medida, são, portanto, dois extremos de compreensão acerca do que é abstrato. Em um extremo, abstrato está ligado à máxima realidade, sendo colocado em completa 
oposição a ela: o que não vejo, toco ou sinto é abstrato. Noutro extremo, além da realidade visível, o conhecimento acerca dos significados de um objeto o tornam concreto, enquanto o abstrato é aquilo ao qual não se pode atribuir significado conhecido.

Assim, em um ou em outro extremo, no senso comum, concreto e abstrato apresentamse em oposição.

A compreensão acerca dos significados desses termos - concreto e abstrato - parece estar relacionada diretamente à experiência de vida de cada sujeito. Ou seja, o que é concreto para uns pode ser abstrato para outros. Para uma criança, a cor é algo associada ao lápis que ela tem em mãos e isso torna a cor concreta para ela. Sem o lápis, a cor não é "palpável” e torna-se objeto abstrato.

Para definir a cor azul podemos nos referir à cor do céu sem nuvens embora o conhecimento técnico possa se referir a qualquer cor como uma faixa de frequência da luz visível do espectro eletromagnético, algo totalmente concreto para os físicos e provavelmente repleto de abstração para um jovem aluno de Ensino Fundamental.

O acompanhamento do processo de construção do conhecimento matemático, durante toda a etapa de formação geral dos estudantes, parece indicar certo sentido num primeiro momento e o sentido inverso no outro. Isto é, em certo momento parece que o processo de construção do conhecimento matemático exige ser percorrido do concreto ao abstrato enquanto, em outro momento, parte-se das abstrações rumo ao estágio final, estruturado sobre o concreto. Comentemos de forma sucinta esses dois percursos.

O senso comum tratou de difundir a perspectiva de que o conhecimento científico é voltado totalmente para as abstrações. O caso da Matemática, nesse contexto é, talvez, o mais emblemático. A Matemática que transpõe os muros do elementar - das contagens, das medidas e das quatro operações - é, na "voz do povo", pura abstração. Percorrer o caminho do conhecimento matemático é, nessa medida, partir do concreto, que já se conhece e se quantifica, em direção ao abstrato, composto pelas teorias, pelos teoremas, pelo exercício da lógica etc. Dessa forma, aponta-se claramente o sentido do percurso da construção do conhecimento matemático: do concreto ao abstrato.

$\mathrm{Na}$ primeira etapa do Ensino Fundamental as crianças manipulam materiais, como barrinhas Cuisenaire, material dourado, massa de modelar, ábacos, tangrans e sólidos de madeira com o objetivo de construírem modelos numéricos e/ou geométricos. Se os modelos 
matemáticos nesse estágio forem considerados abstrações, então o sentido do movimento do pensar das crianças é estabelecido do concreto ao abstrato.

Ninguém jamais viu um número, embora todos, sem exceção, tenhamos tomado contato com as representações de um número, de uma quantidade. Para mostrar sua idade uma criança levanta três dedos; de modo análogo, o comerciante registra a massa de batatas medida na balança. Criança e comerciante, nesses casos, concretizam, através de representações, a abstração numérica que dominam com certa competência. Situações dessa natureza parecem apontar caminho diferente do citado anteriormente, isto é, parecem indicar uma passagem do concreto bruto à representação, ou concreto pensado, como se o estágio final do conhecimento, estimulado a partir das abstrações, fosse o da concretude.

Conduta razoavelmente frequente nos cursos de Matemática no Ensino Médio, nas aulas ou no material didático, consiste na apresentação da definição sobre determinado tema, seguindo-se a aplicação dos conceitos em situações-problema. Assim, no Ensino Médio, o sentido parece inverter-se, partindo do abstrato em direção ao concreto, especialmente nas abordagens conceituais que apresentam aplicações (concreto) apenas quando as definições (abstrato) estão perfeitamente compreendidas.

Existe, enfim, no que se refere ao percurso traçado sobre o eixo que tem num extremo as abstrações e no outro as experiências concretas, sentido mais apropriado à construção do conhecimento em cada segmento de ensino?

A literatura aponta, não sem controvérsias, que a passagem de pensamento entre concreto e abstrato, ou vice-versa, não se configura com a unicidade que parece povoar o senso comum. Sobre isso Machado (2002) escreveu: [...] as abstrações nunca poderiam ser consideradas um ponto de chegada - nem ponto de partida. Elas situam-se no meio do processo; constituem mediações necessárias, nunca um início ou um fim (p. 41), confirmando o que Lefebvre (1983) havia anunciado: Tal como entre o imediato e o mediato, tampouco pode existir entre o abstrato e o concreto uma separação metafísica, uma diferença de natureza. (p. 108)

Nosso processo de aprendizagem começa no dia em que nascemos. Desde cedo aprendemos a olhar, a tocar, a ouvir e distinguir sons, a chorar quando sentimos fome etc. Mais tarde, entramos na escola e iniciamos nosso processo formal de educação, estudando conceitos disciplinares, mesmo que a eles não sejam atribuídos os devidos nomes. Vencendo as diversas etapas de aprendizagem, estamos sempre partindo do concreto e a ele voltando. 
No entanto, na volta não encontramos mais o concreto bruto da partida, mas sim um conjunto de elementos que dominamos e que foram por nós lapidados durante o processo de aprendizagem. Foram as abstrações que nos permitiram transpor de um nível de concretude a outro. Assim ocorre todo o tempo, isto é, as abstrações não são início e nem fim do processo de conhecimento, mas sim os meios que permitem a real construção conceitual, estimulando a superação de níveis de concretude.

Em Tung-Sun (2000) identificamos reflexões que corroboram com as colocações anteriores acerca da dinâmica dos movimentos do pensar entre abstrair e concretizar. Segundo este autor,

[...] existem dois tipos de conhecimento, o perceptivo e o conceitual. Tomemos por exemplo uma mesa ou uma cadeira. Esses objetos podem ser tocados e percebidos, diretamente. É um conhecimento perceptivo. Por outro lado, a uniformidade da Natureza e a noção de um Ser Supremo não podem ser verificadas pelos sentidos, e a casualidade, a teleologia etc., são também de natureza conceitual. (p. 170)

O conhecimento perceptivo citado por Tung-Sun está claramente relacionado à possibilidade de que o objeto de análise possa ser totalmente percebido por sua forma, cor, massa, utilidade etc. Trata-se, portanto, de conhecimento associado à concretude bruta do objeto que se pode tocar e sentir. Já os exemplos que destaca para caracterizar o que classificou por conhecimento conceitual, são claramente construções da mente humana, percebidas através de identificações com signos culturais, e construídas por intermédio de abstrações. Assim, conhecimento perceptivo relaciona-se a concretizar, enquanto conhecimento conceitual relaciona-se a abstrair. Mas, de forma semelhante ao que destacaram Machado (2002) e Lefebvre (1983), escreve Tung-Sun (2000):

Pode-se observar que o conhecimento perceptivo não pode estar fora do conceitual, nem se pode separar o conceitual do perceptivo. Na realidade, todo conhecimento conceitual contém elementos perceptivos e vice-versa. A diferenciação entre os dois visa às simples conveniências de análise. Eles não existem isoladamente. (p. 170)

Dessa forma, apesar de não descrever claramente o sentido da construção do conhecimento, Tung-Sun (2000) aponta a intrínseca relação entre os conhecimentos 
perceptivo e conceitual, caracterizando este último em conhecimento interpretativo, aproximando-o ainda mais das abstrações, como se pode perceber do seguinte trecho:

O conhecimento conceitual é também de natureza interpretativa. Por interpretação, entendemos a manipulação de conceitos e o emprego de categorias. Por exemplo: apreender uma flor é percepção, mas é interpretação dizer que as flores vêm das folhas, ou que a formação da flor tem como objetivo a reprodução. (p.171)

A interpretação do real requer abstrações, de maneira que a natureza interpretativa do conhecimento conceitual origina-se na percepção dos atributos concretos do objeto e manifesta-se por meio das abstrações que o sujeito realiza a partir dos significados que reconhece no objeto. Assim, podemos depreender dos textos de Tung-Sun (2000) uma tendência apontada para a necessidade das abstrações na construção do conhecimento, especialmente quando conclui que: torna-se evidente que o conhecimento conceitual é conhecimento interpretativo, e que o conhecimento interpretativo é conhecimento teórico (p.171).

Conhecimento teórico é, pois, o feixe de relações de significados que coube ao sujeito construir ou ampliar, partindo dos conhecimentos pré-construídos sobre o objeto e mobilizando as abstrações que lhe foram permitidas e estimuladas.

Outros autores com construções teóricas semelhantes apontam na direção destacada por Machado (2009) e por Tung-Sun (2000). Kosik (1976) afirma sobre a questão: O método de ascensão do abstrato ao concreto é o método do pensamento; em outras palavras, é um movimento que atua nos conceitos, no elemento da abstração. (p. 30)

A ideia do conhecimento interpretativo de Tung-Sun (2000) aproxima-se da concepção do método do pensamento de Kosik (1976), e nos permite depreender que as abstrações constituem, de fato, estágio intermediário no sentido da construção do conhecimento concreto, como também destacou Machado (2009).

As hipóteses acerca das relações entre realidade concreta e abstrações na construção do conhecimento matemático remetem a um questionamento sobre as condições que envolvem a maior ou menor eficiência deste processo. Um desses aspectos consiste na importância que contextos de trabalho representam enquanto meios para o desenvolvimento das necessárias abstrações ou, de outra forma, para aproximá-las do concreto. 
Admitindo que o conhecimento sobre o objeto torna-o concreto na medida em que somos capazes de perceber e de utilizar as múltiplas relações de significado existentes entre elementos próprios do objeto e também para além dele, podemos compreender o caminho do conhecimento sobre o objeto segundo o modelo de algo que se inicia no concreto e a ele retorna. Ou seja, partimos daquilo que conhecemos sobre o objeto para ampliarmos esse conhecimento e voltarmos a ele, vendo-o, agora, em relações de naturezas diferentes daquelas que víamos inicialmente. São, portanto, dois estágios de concretude, definidos e diferenciados pela quantidade e qualidade das relações de significado que conseguimos estabelecer, interna e externamente ao objeto de estudo.

Acerca desse movimento entre concretizar e abstrair, Rambaldi (1988) anuncia:

Melhor será portanto referir que o processo de abstração, ou seja, a análise e decomposição do concreto, é sempre e apenas a primeira parte da construção científica, a qual - partindo deste limite extremo da mais rarefeita simplicidade - inverte o seu caminho para dar início, através da síntese e recomposição, à reconstrução do real, enfim tornado apreensível. ( p.176)

São, pois, dois estágios de concretude, mediados por procedimentos de análise e decomposição do conhecimento inicial do objeto e por síntese e recomposição, com vistas à construção do conhecimento final. O "elevador" que permite superar um estágio e atingir o próximo é formado pelo conjunto das abstrações que realizamos, com base nas características dos elemeptos que formam o conjunto de circunstâncias na qual o objeto se apresenta ou, em outras palavras, com base no contexto de ensino.



Objeto conhecido: tornado concreto ao sujeito através das relações de significado que construiu. Ocorre que tais relações são variadas e o sujeito identifica apenas algumas a cada momento. O concreto está no objeto e o abstrato fora dele.

$\mathrm{Na}$ ampliação do conhecimento sobre o objeto reside a importância da escolha de contexto adequado. $\mathrm{O}$ contexto estimula a construção de novas relações de significado.

Novas relações de significados conceituais são estabelecidas; o conhecimento concreto sobre o objeto é ampliado. Novas ampliações implicam em reviver $\mathrm{o}$ 


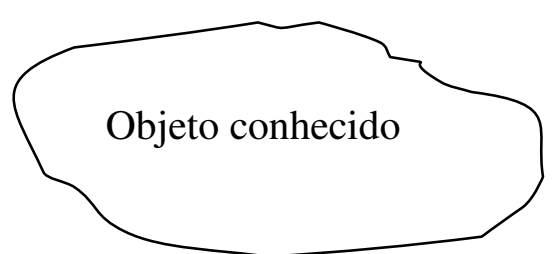

Concluindo, em relação à construção do conhecimento que se efetiva com base na concepção da rede de significados, formulamos duas premissas. A primeira delas refere-se ao caminho da construção conceitual, que parte sempre do concreto e a ele retorna, fortalecido pelas novas relações de significados que foram estabelecidas durante o processo. Como segunda premissa, entendemos que o caminho de um estágio a outro de concretude, com a qualidade das abstrações exigidas, necessita que o objeto seja visto como um elemento pertencente a um conjunto infinito, caracterizado por condições determinadas, no qual as relações entre significados sejam claramente identificadas e possam estimular a construção do conhecimento do objeto.

Dito de outra forma, entendemos que a interpretação do que seja concreto, no nível do conhecimento que se constrói, oscila entre o que é palpável e o que tem significado, embora não se configure, na questão, nenhuma mútua exclusividade. Confirmamos, assim, a existência de objetos palpáveis ou não, conhecidos e desconhecidos. Confirmamos ainda que, com base na concepção do conhecimento que se constrói com base na metáfora da rede, um objeto exige ser visto entretecido por múltiplas relações de significados, e que a construção desse tecido de relações pelo sujeito do conhecimento pode ser estimulada por sua vivência em um processo educativo que considere a importância do âmbito em que tais relações se evidenciam. Assim, na tarefa docente, ensinar buscando o concreto, em qualquer nível, é ensinar buscando o contexto.

As características da composição de um contexto de ensino serão abordadas no Capítulo 3. Entretanto, antes disso, no Capítulo 2, analisaremos a noção de ensino contextualizado expressa nas diretrizes de alguns documentos e avaliações oficiais. Por ora, fiquemos com a colocação de Egan (2002) que reforça a importância dos contextos sobre os quais enxergamos os objetos de estudo: Sem conexão com algumas sustentações abstratas o conteúdo concreto ou as manipulações práticas permanecem descontextualizadas e, mais geralmente, desprovidas de sentido. (p. 80) 


\section{CAPÍtulo 2 - A POlisSemia do CONTEXTo}

Cada coisa sobre a qual o homem concentra seu olhar, a sua atenção, a sua ação ou a sua avaliação, emerge de um determinado todo que a circunda [...]. (Karel Kosik)

\subsection{INTRODUÇÃO}

Tornou-se frequente a argumentação, em várias instâncias, a respeito da necessidade de contextualização do ensino em todos os segmentos de ensino. Farta também é a argumentação que imprime à ausência da contextualização boa parcela da responsabilidade do aprendizado deficiente dos alunos em Matemática. O significado maior da contextualização, visto sob o prisma do senso comum, diz respeito unicamente à condução dos conteúdos matemáticos em direção às suas aplicações cotidianas e imediatas. Sob tal visão, contextualizar o ensino está diretamente relacionado à busca de respostas à intrigante questão dos alunos que, vez por outra, acompanha a exposição de tópicos de conteúdo: $\underline{\text { Para que serve }}$ isso que estamos aprendendo?

Em acordo com uma proposta de ensino contextualizado de Matemática, entendemos que melhor seria buscar respostas à outra questão, em substituição à anterior, com a seguinte

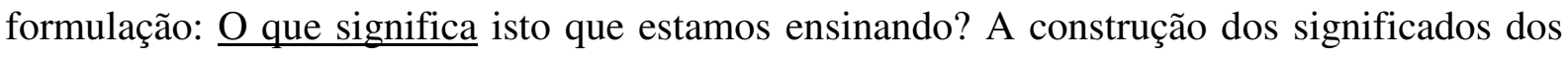
objetos, nesta ideia, está fortemente relacionada ao contexto de ensino adotado para a apresentação dos conteúdos.

No sentido de iniciar a verificação da hipótese arrolada no parágrafo anterior, analisaremos neste capítulo algumas concepções sobre a contextualização do ensino presentes em documentos oficiais, além de casos de avaliações oficiais cujas questões foram elaboradas sob a égide da contextualização. 


\subsection{ENSINO E CONTEXTUALIZAÇÃO: CONCEPÇÕES E EQUÍVOCOS}

O termo "contexto" é visto com significado estrito a cada campo de conhecimento em que se aplica e, para compreender e limitar o campo de aplicação do termo às situações pertinentes à validação de nossa tese, consideramos necessário analisar a presença do "contexto" em alguns desses campos para, em seguida, delimitar os significados que podemos relacionar diretamente às funções pedagógicas.

A origem do termo está associada a contextus, do verbo latino contextére, que significa entrelaçar, reunir, tecer, compor. Uma consulta ao dicionário fornece alguns dos significados atuais que podemos atribuir à palavra "contexto":

- inter-relação de circunstâncias que acompanham um fato ou uma situação.

- conjunto de palavras, frases, ou o texto que precede ou se segue a determinada palavra, frase ou texto, e que contribuem para o seu significado; encadeamento do discurso. ${ }^{1}$

Em concordância com essas clássicas definições, entendemos contextos como conjuntos de circunstâncias capazes de estimularem relações entre significados conceituais. A viabilização desta ação ocorre, principalmente, quando essas circunstâncias caracterizam-se a partir de elementos que podem ser claramente associados à cultura dos sujeitos envolvidos, como comentaremos adiante neste trabalho.

Em primeira instância, a criação de um contexto para estudos de conceitos de determinada área de conhecimento exige a seleção de um conjunto de situações relacionáveis entre si por alguma motivação, a partir do conhecimento daquele que o organiza, quase sempre o professor. Dentre as várias motivações pertinentes a esse caso, no plano da elaboração das atividades curriculares, podemos citar a aplicabilidade dos conceitos em situações do cotidiano, os aspectos relacionados à evolução histórica dos conceitos, as ligações percebidas dos conceitos para além dos muros da disciplina e as relações conceituais que se estabelecem internamente à disciplina. De qualquer forma, na constituição de um contexto para as atividades que serão desenvolvidas, cabe ao professor identificar, para além da motivação das relações conceituais existentes, a carga de significatividade que se impõe a

\footnotetext{
${ }^{1}$ In: http://houaiss.uol.com.br/busca.jhtm?verbete=contexto\&stype=k\&x=14\&y=12 (acesso em 24/12/2010)
} 
partir dos elementos contextuais. No documento Orientações curriculares para o Ensino Médio - Ciências da Natureza, Matemática e suas Tecnologias, do Ministério da Educação, podemos ler:

É na dinâmica de Contextualização/descontextualização que o aluno constrói conhecimento com significado, nisso se identificando com as situações que lhe são apresentadas, seja em seu contexto escolar, seja no exercício de sua plena cidadania. A contextualização não pode ser feita de maneira ingênua [...]. Em outras palavras, a contextualização aparece não como uma forma de "ilustrar" o enunciado de um problema, mas como uma maneira de dar sentido ao conhecimento matemático na escola. (2006, p. 83)

Assim, em acordo com esse documento, não se justifica que, na busca da contextualização do estudo, sejam compostos cenários e/ou narrativas que tão somente apresentem os conceitos "maquiados" em situações fictícias, pretensamente concretas. Tal conduta, entretanto, é frequente na composição de "enredos" para o ensino de conteúdos, tanto no Ensino Fundamental quanto no Ensino Médio, e não apenas na disciplina de Matemática.

Vejamos o que se pode ler em um documento oficial sobre o ensino das disciplinas da área de Ciências Humanas e suas Tecnologias:

A tradição existente, senão em todas mas ao menos na maioria das propostas de trabalho que envolvem as disciplinas da área de Ciência Humanas e suas Tecnologias, costuma vincular a noção de contexto à condição de conjunto de aspectos gerais, que supostamente fazem as vezes de "pano de fundo" ou "cenário" no qual se desdobram os acontecimentos [...]. No entanto, quando aqui nos referimos à noção de contextualização como parte necessária da prática docente comum, que alicerça um trabalho efetivamente interdisciplinar, estamos apontando para uma outra direção, qual seja, a significação dos temas/assuntos a serem estudados pelos educandos, no âmbito do viver em sociedade amplo e particular dos mesmos. (MEC, ${ }^{2} 2002$, p.22)

Nota-se, pela leitura desse trecho da proposta de orientações para o trabalho docente na área das Ciências Humanas e suas Tecnologias, a preocupação com a criação de contextos que associem significados importantes aos conceitos envolvidos. A busca pela

\footnotetext{
${ }^{2}$ PCN+ Ensino Médio - Ciências Humanas e suas Tecnologias.
} 
interdisciplinaridade, claramente exposta no texto, deve orientar a contextualização dos conteúdos, visando possibilitar no educando ampla compreensão dos fenômenos sociais, em todas as esferas do conhecimento, contribuindo, dessa maneira, para sua formação integral e cidadã. Trata-se, portanto, de orientação geral para a elaboração de currículos, que pode ser colocada acima das particularidades das disciplinas.

A interdisciplinaridade, isto é, a identificação e o relacionamento de diferentes significados de um conceito em disciplinas de mais de uma área do conhecimento, deve ser, segundo documentos oficiais, ponto de partida para a criação de contextos, e não apenas nas Ciências Humanas: [...] o importante é ampliar as possibilidades de interação não apenas entre as disciplinas nucleadas em uma área como entre as próprias áreas de nucleação. A contextualização pode ser um recurso para conseguir esse objetivo. (MEC ${ }^{3} .2002$, p. 91)

Entendemos que em nome da elaboração de contextos interdisciplinares no Ensino Médio, tantas vezes estimulada por documentos oficiais, são cometidos desvios que revelam a incompreensão acerca do significado da contextualização. Uma das maneiras de identificarmos com clareza tais equívocos, consiste na análise de itens de avaliação presentes em provas de alguns exames oficiais ou concursos vestibulares. A Revista do Professor de Matemática, publicação da Sociedade Brasileira de Matemática, por exemplo, sob o título “Contextualização ou insensatez?", destaca uma questão elaborada para determinado concurso de professores. Eis o enunciado de tal questão:

Um ornitólogo conclui, a partir de suas pesquisas, que a altura máxima que os indivíduos de determinada espécie de pássaros conseguem atingir durante o voo é, em $\mathrm{km}$, igual à metade do quadrado da maior distância entre dois números complexos que satisfazem a equação $z^{3}=8 i$. Nessa situação, a altura máxima atingida pelos indivíduos dessa espécie é: (RPM, n 72. São Paulo: SBM, 2010. p. 47)

A relação entre os números complexos e a altitude atingida por pássaros é, sem dúvida, de mesma intensidade daquela existente entre, por exemplo, a quantidade de dentes de um jacaré e o preço de uma maçã; isto é, nenhuma. A insensatez no reconhecimento do que seja contexto, apontado na revista, parece estar mais próximo das situações didáticas do que se imagina.

\footnotetext{
${ }^{3}$ PCN+ Ensino Médio - Ciências Humanas e suas Tecnologias
} 
Como se pode perceber por esse exemplo, os méritos da ideia da contextualização atolam, por vezes, na exagerada apologia de que tudo deve ser trazido à realidade do aluno; é preciso concretizar, tornar próximo. Para tanto, elaboram-se narrativas que nenhum significado importante acrescenta aos conceitos, permitindo apenas, ainda assim de forma duvidosa, que os estudantes se motivem para enfrentar a situação proposta. A interdisciplinaridade, propalada nos documentos oficiais, não está sempre presente, portanto, na mente daqueles que elaboram as questões de algumas provas.

Vejamos outro exemplo de item de avaliação com enunciado pretensamente contextualizado, envolvendo conteúdos de Física ${ }^{4}$ :

Foi que ele viu Juliana na roda com João

Uma rosa e um sorvete na mão

Juliana seu sonho, uma ilusão

Juliana e o amigo João

GIL, Gilberto. Domingo no parque.

A roda citada no texto é conhecida como RODA-GIGANTE, um brinquedo de parques de diversões, no qual atuam forças, como a força centrípeta.

Considere:

- o movimento uniforme;

- o atrito desprezivel;

- a aceleração da gravidade local de $10 \mathrm{~m} / \mathrm{s}^{2}$

- massa de Juliana, $50 \mathrm{~kg}$

- raio da roda-gigante, 2 metros

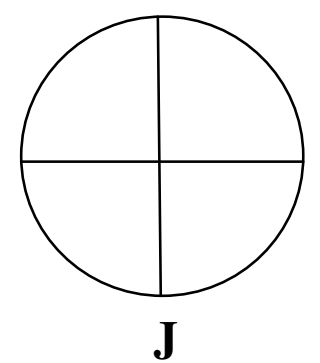

- velocidade escalar constante, com que a roda está girando, $36 \mathrm{~km} / \mathrm{h}$.

Calcule a intensidade da reação normal que a cadeira exerce sobre Juliana quando a menina se encontra na posição indicada pelo ponto J.

O enunciado dessa questão parece impor ao leitor a ideia de que o conhecimento anterior do candidato sobre a bela composição de Gilberto Gil o auxiliará a calcular corretamente o valor da resultante de forças sobre Juliana, o que é um equívoco. De outra forma, o "contexto" da questão parece ter sido elaborado com o objetivo apenas de amortecer

\footnotetext{
${ }^{4}$ Vestibular da UFRJ, 2005.
} 
o contato do candidato com a aplicação da fórmula da resultante centrípeta no ponto inferior de um movimento circular, o que transforma o enunciado em um complicador para aqueles que conhecem os conceitos necessários à resolução da questão. Em outros termos, a interpretação dos versos fornecidos não impele qualquer significado adicional ao cálculo da força centrípeta.

Em relação a esse exemplo de cálculo da força centrípeta, podemos considerar várias propostas de reflexões que permitam o estabelecimento de relações entre significados. Em um desses casos, poderíamos fornecer ao estudante informações a respeito dos efeitos do movimento sentidos por Juliana em alguns pontos, e questioná-lo sobre as características da força centrípeta nesses pontos, relacionando, dessa forma, expressões matemáticas às sensações do sujeito que brinca na roda gigante.

Significados podem ser construídos nas relações que se estabelecem internamente à área de conhecimento, desprezando-se, dessa maneira, a criação de subterfúgios pretensamente interdisciplinares.

Princípios e ideias gerais, concebidos para aplicação em determinados âmbitos e condições, quando transportados acriticamente para situações de outras naturezas que não as originais, podem contribuir para sua banalização. Acreditamos que essa banalização esteja ocorrendo com a ideia da contextualização do ensino da Matemática.

\subsection{O Exame nacional do Ensino Médio (ENEM) e os Parâmetros Curriculares Nacionais (PCNs)}

O Exame Nacional do Ensino Médio (ENEM) foi criado em 1998 com o objetivo de avaliar a mobilização do seguinte conjunto de cinco competências gerais, por parte de alunos que completam a etapa final da educação básica:

I) Capacidade de expressão em diferentes linguagens.

II) Capacidade de compreensão de fenômenos.

III) Capacidade de enfrentar situações-problema em diferentes contextos.

IV) Capacidade de construir argumentações consistentes;

V) Capacidade de elaborar propostas de intervenção solidária na realidade. 
Para viabilizar a realização das questões de prova, esse conjunto de competências estava associado a 21 habilidades, cada uma delas associada a uma ou mais competências. As questões objetivas da prova eram elaboradas de maneira que cada habilidade pudesse ser avaliada três vezes, permitindo que a prova fosse constituída por 63 questões.

No documento Relatório Pedagógico ENEM 2007, referente ao exame original, encontramos as intenções dos elaboradores acerca das características gerais da prova objetiva:

Nas questões de múltipla escolha da parte objetiva da prova, o participante exerce o papel de leitor do mundo que o cerca. São propostas a ele situaçõesproblema originais devidamente contextualizadas (grifo nosso) na interdisciplinaridade das ciências, das artes e da filosofia, em sua articulação com o mundo em que vivemos. Utilizam-se dados, gráficos, figuras, textos, referências artísticas, charges, algoritmos, desenhos, ou seja, todas as linguagens possíveis para veicular dados e informações (MEC, p. 52)

Os pressupostos para elaboração da prova do ENEM apontavam claramente, em 1998, a perspectiva de contextos produzidos a partir da utilização de diferentes linguagens, e em concordância com situações reconhecidas pelo avaliando como constituintes de seu universo vivencial. Ou seja, a elaboração de questões para o ENEM baseava-se, em primeira instância, nas relações interdisciplinares e, para além delas, nas relações entre significados conceituais identificados com práticas cotidianas. Por isso a expectativa sobre a postura de leitor de mundo, expressa no documento.

Contrariamente à proposta inicial, o ENEM acabou contribuindo para a banalização da ideia de contextualização. Por vários motivos - ranqueamento, contagem de pontos para vestibulares, prestígio etc. - o ENEM adquiriu importância maior junto às escolas de Ensino Médio, que passaram a direcionar seus cursos como preparação para o ENEM, sem perceberem que as questões que compunham originalmente esse exame eram desenvolvidas sobre contextos próximos da realidade do estudante do Ensino Médio, embora não exigissem, explicitamente, o conhecimento de conteúdos específicos das disciplinas. 
O ENEM sofreu mudanças em 2009. Mantidas as cinco competências gerais originais, denominadas agora "Eixos cognitivos", o novo ENEM buscou maior aproximação entre os conteúdos das disciplinas e tais competências, com o objetivo de ampliar o espectro de orientações para ações didáticas e avaliações de aprendizagem. Para tanto, o conhecimento foi organizado em quatro áreas ${ }^{5}$, cada uma delas com determinadas competências específicas. Com base nessas competências específicas foram elaboradas as questões do exame.

Em cada uma das quatro áreas o exame, a partir de 2009, passou a ser composto por 45 questões de múltipla escolha que merecem comentário em relação à proposta de contextualização que balizou sua elaboração.

Identificamos em várias questões a constituição de contexto a partir de ideias contidas em textos longos, que exigiam do candidato a leitura e a intersecção de várias informações. De fato, a criação de um contexto exige a tecedura de condições que possam agregar significados aos objetos de estudo, ação esta que melhor se traduz por intermédio de um texto (dissertativo, informativo, narrativo etc.). Observemos o seguinte exemplo do exame de 2009:

A evolução da luz: as lâmpadas LED já substituem com grandes vantagens a velha invenção de Thomas Edison.

A tecnologia do LED é bem diferente das lâmpadas incandescentes e das fluorescentes. A lâmpada LED é fabricada com material semicondutor semelhante ao usado nos chips de computador. Quando percorrido por uma corrente elétrica, ele emite luz. O resultado é uma peça muito menor, que consome menos energia e tem uma durabilidade maior. Enquanto uma lâmpada comum tem vida útil de 1.000 horas e uma fluorescente, de 10.000 horas, a LED rende entre 20.000 e 100.000 horas de uso ininterrupto.

Há um problema, contudo: a lâmpada LED ainda custa mais caro, apesar de seu preço cair pela metade a cada dois anos. Essa tecnologia não está se tornando apenas mais barata. Está também mais eficiente, iluminando mais com a mesma quantidade de energia.

Uma lâmpada incandescente converte em luz apenas $5 \%$ da energia elétrica que consome. As lâmpadas LED convertem até 40\%. Essa diminuição no desperdício de energia traz benefícios evidentes ao meio ambiente.

(Revista Veja, 19 dez. 2007. Disponivel em: http://veja.abril.com.br/191207/p_118.shtml)

\footnotetext{
${ }^{5}$ As quatro áreas do ENEM 2009: Matemática, Linguagens, Ciências da Natureza e Ciências Humanas.
} 
Considerando que a lâmpada LED rende 100 mil horas, a escala de tempo que melhor reflete a duração dessa lâmpada é o:
(A) dia
(B) ano
(C) decênio
(D) século
(E) milênio

No caso dessa questão, o longo texto que forma o enunciado apresenta uma série de dados e informações completamente irrelevantes para a resolução que exige. A busca do candidato pela correta resolução, lendo e interpretando as informações textuais, não converge para a construção de qualquer significado maior do que aquele associado a simples conversão entre unidades de medidas de tempo.

Sem a intenção de questionar a pertinência das questões quanto ao objetivo avaliativo com que foram elaboradas, vale questionar se os longos textos que compuseram os enunciados podem ser considerados elementos de contextualização significativa para a apresentação de situações-problema. O fato de a média de Matemática dos avaliados em 2009 ter sido a menor dentre todas as disciplinas é, sem dúvida, indício da deficiência de nosso processo de ensino-aprendizagem em Matemática, mas pode ser também reflexo do modelo de questão escolhido para a constituição do exame.

A compreensão do que seja o contexto sobre o qual se elaboram as questões objetivas da prova do ENEM relaciona-se à construção de relações entre conceitos básicos das ciências, em todos os âmbitos, e na identificação da presença de tais conceitos em situações cotidianas. Assim, para o ENEM, contextualizar implica em relacionar ideias, fatos, situações, personagens etc., por intermédio de elementos em diferentes linguagens. Em princípio, portanto, louve-se a proposta do ENEM, embora a viabilização das ideias gerais, por intermédio das questões apresentadas aos estudantes, nem sempre ocorra da maneira esperada.

Consideremos outro exemplo de questão modelo da prova de 2009:

Uma pessoa de estatura mediana pretende fazer um alambrado em torno do campo de futebol de seu bairro. No dia da medida do terreno, esqueceu de levar a trena para realizar a medição. Para resolver o problema, a pessoa cortou uma vara de comprimento igual a sua altura. O formato do campo é retangular e foi constatado que ele mede 53 varas de comprimento e 30 varas de largura. 
Uma região $R$ tem área $A_{R}$, dada em $\mathrm{m}^{2}$, de mesma medida do campo de futebol, descrito acima.

A expressão algébrica que determina a medida da vara em metros é:
a) Vara $=\sqrt{\frac{A_{R}}{1500}} m$
b) Vara $=\sqrt{\frac{A_{R}}{1590}} m$
c) $\operatorname{Vara}=\frac{1590}{A_{R}} m$
d) $\operatorname{Vara}=\frac{A_{K}}{1500} m$
e) $\operatorname{Vara}=\frac{A_{R}}{1590} m$

Na composição do enunciado dessa questão, considerou-se que a realização de medidas com instrumentos não padronizados constitui-se em prática do cotidiano. Trata-se, portanto, de premissa válida para a elaboração de conjunto de situações que formam contexto apropriado à questão proposta. Todavia, a pergunta final não estabelece sentido algum com a descrição anterior, visto que o objetivo do procedimento descrito é a determinação da área do campo de futebol, e não a medida da vara. Atribuir-se significado à expressão de cálculo da medida da vara a partir da medida da área, tem semelhança com o dito popular associado ao ato de inverter-se a ordem natural dos acontecimentos, que se resume a "colocar o carro à frente dos bois". Dessa forma, a narrativa inicial não se relaciona com o desafio proposto, de maneira que não cabe ao estudante associar nenhum significado adicional à obtenção da expressão algébrica esperada.

Se na questão anterior, sobre $A$ evolução da luz detectamos a construção de contexto com base em texto longo e desnecessário à resolução, nesta última questão, da medida da vara, notamos uma tentativa frustrada de associar contexto à aplicabilidade do conceito em situação cotidiana.

Comparando a estrutura do ENEM original, de 1998, com a estrutura da prova atual, a partir de 2009, percebemos que em ambas destaca-se a importância da contextualização do ensino, como procedimento esperado para a ligação entre as disciplinas e competências (ou eixos cognitivos).

\begin{tabular}{|c|c|c|}
\hline \multicolumn{2}{|c|}{ ENEM } \\
\hline & 1998 & 2009 \\
\hline Competências (eixos cognitivos) & 5 & 5 \\
\hline Competências da área & ---- & 7 \\
\hline
\end{tabular}




\begin{tabular}{|c|c|c|}
\hline Habilidades & 21 & 30 \\
\hline
\end{tabular}

A partir de 2009, o ENEM passou ainda a divulgar uma lista de "objetos do conhecimento" que embasa a elaboração das questões. Tal lista, na verdade, explicita os conteúdos cujos conhecimentos serão exigidos dos estudantes no sentido de avaliar se desenvolveram ou não a competência esperada.

A dificuldade maior na elaboração das questões do ENEM, no antigo ou no atual, é a mesma, ou seja: como articular disciplinas e competências? A busca pela superação de tal dificuldade passa pela adoção de contextos adequados.

A ideia de contextualizar o ensino, no senso comum estreitamente ligada ao conceito do que seja conhecimento concreto, reflete-se, além das esferas das avaliações do ENEM e de outros exames, em propostas para a apresentação de conceitos matemáticos, como, por exemplo, aquela em que alunos de $2^{\circ}$ ano de Ensino Médio se envolvem com a construção de sólidos geométricos em papel cartão, para depois medir suas dimensões e avaliar volume, área, diagonal etc., com o objetivo de estudar elementos de geometria métrica espacial. Propostas de trabalho dessa natureza podem relegar ao segundo plano a necessária abstração dos alunos, notadamente na faixa etária em questão. Trata-se, portanto, de algo a ser investigado: em que medida o conhecimento que o aluno constrói, em cada etapa de aprendizagem, exige a associação dos conceitos a situações caracterizadas pela concretude bruta, formada por elementos possíveis de serem tocados, moldados, pesados que, dessa maneira, participam da criação dos contextos de ensino.

Resolvemos situações-problema envolvendo retângulos sem jamais termos tocado em um deles, e nem poderíamos vir a fazê-lo. Calculamos medidas de diagonais, perímetros, áreas etc., a partir da representação mental que fazemos do polígono, pelo conhecimento que temos de suas propriedades - paralelismo entre lados, ângulos retos, lados congruentes. Assim, um retângulo - objeto abstrato - é feito concreto a partir das relações de significado que estabelecemos entre suas propriedades. Ou seja, um retângulo, bem como qualquer outro ente geométrico é, na verdade, um feixe de múltiplas relações, ampliadas à medida que evoluímos no conhecimento sobre o objeto. Desse modo, nosso conhecimento é construído à medida que conseguimos estabelecer relações de significados estimuladas pelo contexto sobre o qual tomamos contato com o objeto. As abstrações, nesse processo, desempenham papel preponderante 
O documento Parâmetros Curriculares para o Ensino Médio (PCNEM) em conformidade com as Diretrizes Curriculares Nacionais para o Ensino Médio (DCNEM), de junho de 1998, e recuperando aspectos das Diretrizes e Bases da Educação Nacional (LDB), de 1996, dá destaque especial ao tema da contextualização do ensino. Identificamos semelhanças no conjunto das diretrizes apontadas no documento com a proposta do ENEM, na medida em que expressa:

Contextualizar o conteúdo que se quer aprendido significa, em primeiro lugar, assumir que todo conhecimento envolve uma relação entre sujeito e objeto. ... A contextualização evoca por isso áreas, âmbitos ou dimensões presentes na vida pessoal, social e cultural. (p. 91)

Dessa forma, as Diretrizes da Educação Nacional apontam, em concordância com os pressupostos da prova do ENEM, a necessidade do estabelecimento de relações entre significados conceituais, próprios das ciências e/ou da cultura do sujeito de modo geral, como condição fundamental para a contextualização do estudo. De fato, se a produção de significados ocorre, como Bruner (2001) assim descreve: O significado de qualquer fato, proposição ou encontro é relativo à perspectiva ou quadro de referência a partir do qual é construído (p. 24), torna-se necessário colocar os estudantes em contato com situações em que o conceito analisado possa ser visto em relações estabelecidas a partir dos significados que o constituem. Por exemplo, o estudo das funções trigonométricas (seno, cosseno e tangente), realizado normalmente entre o $1^{\circ}$ e o $2^{\circ}$ anos do Ensino Médio, parte da necessidade de modelarmos fenômenos periódicos, segundo modelo ondulatório. Com estas funções podemos modelar de modo aproximado, por exemplo, o subir e descer das marés. A análise da periodicidade de fenômenos como a propagação sonora, a escala musical, a geração e repetição de sinais eletromagnéticos, pode juntar-se à preocupação da humanidade na elaboração dos primeiros calendários, construídos a partir da regularidade dos movimentos aparentes do sistema Terra-Sol-Lua. Portanto, a apresentação das funções trigonométricas aos alunos sem considerar a existência de um quadro de referência que envolva alguns desses fenômenos, ou ainda outros que pudermos selecionar, provavelmente não se configurará em trabalho contextualizado.

A contextualização do ensino, portanto, anuncia-se nesses documentos como alternativa real para a confrontação dos sujeitos com o conjunto das circunstâncias que caracterizam sua vivência cultural. Tendo em vista tal condição, a questão que se coloca em seguida é: "Quais são os elementos apontados nos documentos para a composição de 
contextos, tendo em vista a aprendizagem dos sujeitos nas condições da proposta geral de formação expressa na LDB?"

Nas Diretrizes Curriculares Nacionais para o Ensino Médio são apontados os elementos contextuais considerados relevantes. São eles: o trabalho e a cidadania. Nos PCNs do Ensino Médio podemos ler:

As dimensões de vida ou contextos valorizados explicitamente pela $L D B$ são o trabalho e a cidadania. (p.91)

O trabalho é o contexto mais importante da experiência curricular no Ensino Médio, de acordo com as diretrizes traçadas pela LDB em seus Artigos 35 e 36. (p. 92)

Outro conceito relevante indicado pela LDB é o exercício da cidadania. (p. 93)

Ressalve-se que a perspectiva apontada nos PCNs, quanto ao princípio organizador do currículo de Ensino Médio orientado para contextualização não implica em condicionar o estudo dos conteúdos para fins imediatistas e profissionalizantes, da formação técnica e objetiva para determinado fim profissional. Pelo contrário, segundo os PCNs,

[...] a lei reconhece que, nas sociedades contemporâneas, todos, [...] devem ser educados na perspectiva do trabalho enquanto uma das principais atividades humanas, enquanto campo de preparação para escolhas profissionais futuras, enquanto exercício de cidadania, enquanto processo de produção de bens, serviços e conhecimentos com as tarefas laboriais que lhe são próprias. (p. 92)

Nessa medida, os preceitos descritos nos PCNs com vistas à contextualização apontam para a interdisciplinaridade claramente expressa pelas intrínsecas relações de dependência conceitual, como, por exemplo, as existentes entre o estudo das funções elementares e o das características dos movimentos em Física, ou ainda o estudo dos gases na Química. Mas, para além disto, apontam para a inclusão nos currículos de temas bastante amplos, que extrapolam o âmbito das disciplinas e as colocam a serviço da construção da cidadania, temas de características transdisciplinares como, por exemplo, a análise da produção de serviços de saúde, questões relativas ao meio ambiente, aspectos da geração e utilização da energia, as práticas sociais, políticas e culturais etc. 
Algumas características apontadas nos PCNs a respeito da contextualização do ensino podem ser observadas também na proposta do "novo ENEM", de 2009. Tal reconhecimento pode ser realizado a partir da leitura de alguns documentos que referenciam a proposta desse exame nacional. Por exemplo, na proposta apresentada pelo Ministério da Educação à ANDIFES, Associação Nacional dos Dirigentes das Instituições Federais de Ensino Superior, a respeito da implantação do ENEM, podemos ler que:

Assim, o novo exame seria composto por quatro testes, um por cada área do conhecimento, a saber: (i) Linguagens, Códigos e suas Tecnologias (incluindo redação); (ii) Ciências Humanas e suas Tecnologias; (iii) Ciências da Natureza e suas Tecnologias; e (iv) Matemática e suas Tecnologias. Esta estrutura aproximaria o exame das Diretrizes Curriculares Nacionais e dos currículos praticados nas escolas, mas sem abandonar o modelo de avaliação centrado nas competências e habilidades ${ }^{6}$.

A aproximação da proposta do novo ENEM das Diretrizes Curriculares Nacionais e, portanto, dos PCNs, nos leva a crer que as questões do exame sejam formuladas a partir de contextos do mundo do trabalho e da cidadania, como apontado anteriormente. A análise da matriz de referência para a elaboração da prova permite, entretanto, a identificação de outros elementos importantes na formação contextual. Especificamente no caso da Matemática e suas tecnologias, destaquemos as sete competências e algumas das trinta habilidades expressas na matriz ${ }^{7}$ :

Competência de área 1 - Construir significados para os números naturais, inteiros, racionais e reais.

H1 - Reconhecer, no contexto social, diferentes significados e representações dos números e operações - naturais, inteiros, racionais ou reais.

Competência de área 2 - Utilizar o conhecimento geométrico para realizar a leitura e a representação da realidade e agir sobre ela.

H9 - Utilizar conhecimentos geométricos de espaço e forma na seleção de argumentos propostos como solução de problemas do cotidiano.

\footnotetext{
${ }^{6}$ Recolhido no endereço:

http://portal.mec.gov.br/index.php?option=com_content\&view=article\&id=13318\&/temid=310, em novembro/2010.

${ }^{7}$ Todos os grifos são nossos.
} 
Competência de área 3 - Construir noções de grandezas e medidas para a compreensão da realidade e a solução de problemas do cotidiano.

H11 - Utilizar a noção de escalas na leitura de representação de situação do cotidiano.

Competência de área 4 - Construir noções de variação de grandezas para a compreensão da realidade e a solução de problemas do cotidiano.

H17 - Analisar informações envolvendo a variação de grandezas como recurso para a construção de argumentação.

Competência de área 5 - Modelar e resolver problemas que envolvem variáveis socioeconômicas ou técnico-científicas, usando representações algébricas.

H22 - Utilizar conhecimentos algébricos/geométricos como recurso para a construção de argumentação.

Competência de área 6 - Interpretar informações de natureza científica e social obtidas da leitura de gráficos e tabelas, realizando previsão de tendência, extrapolação, interpolação e interpretação.

H26 - Analisar informações expressas em gráficos ou tabelas como recurso para a construção de argumentos.

Competência de área 7 - Compreender o caráter aleatório e não determinístico dos fenômenos naturais e sociais e utilizar instrumentos adequados para medidas, determinação de amostras e cálculos de probabilidade para interpretar informações de variáveis apresentadas em uma distribuição estatística.

H30 - Avaliar propostas de intervenção na realidade utilizando conhecimentos de estatística e probabilidade.

Os grifos no texto do documento destacam elementos como intervenção na realidade, fenômenos naturais e sociais, variáveis socioeconômicas ou técnico-científicas, problemas do cotidiano, situações do cotidiano, contexto social, representação da realidade, elementos estes que orientam a elaboração de questões com base em contextos que podem considerar condições do mundo do trabalho e da cidadania, e também condições da produção e dos fins da ciência, da cultura e da tecnologia. Os enunciados seguintes, extraídos de questões da prova modelo de 2009, nesse sentido, são exemplares. 
Questão 7 - A cada ano, a Amazônia Legal perde, em média, 0,5\% de suas florestas. $O$ percentual parece pequeno, mas equivale a uma área de quase 5 mil quilômetros quadrados. Os cálculos feitos pelo Instituto do Homem e do Meio Ambiente da Amazônia (Imazon) apontam um crescimento de $23 \%$ na taxa de destruição da mata em junho de 2008, quando comparado ao mesmo mês do ano 2007. Aproximadamente 612 quilômetros quadrados de floresta foram cortados ou queimados em quatro semanas. Nesse ritmo, um hectare e meio (15 mil metros quadrados ou pouco mais de um campo de futebol) da maior floresta tropical do planeta é destruído a cada minuto. A tabela abaixo mostra dados das áreas destruídas em alguns estados brasileiros. (p.9)

Questão 8 - Um desfibrilador é um equipamento utilizado em pacientes durante parada cardiorrespiratória com objetivo de restabelecer ou reorganizar o ritmo cardíaco. O seu funcionamento consiste em aplicar uma corrente elétrica intensa na parede torácica do paciente em um intervalo de tempo da ordem de milissegundos. (p.10)

Questão 9 - As condições de saúde e a qualidade de vida de uma população humana estão diretamente relacionadas com a disponibilidade de alimentos e a renda familiar. $O$ gráfico I mostra dados da produção brasileira de arroz, feijão, milho, soja e trigo e do crescimento populacional, no período compreendido entre 1997 e 2003. O gráfico II mostra a distribuição da renda familiar no Brasil, no ano de 2003. (p.11)

A questão 7 foi formulada a partir de conjunto de dados referentes ao desmatamento ocorrido na Amazônia e em estados brasileiros, tratando-se, portanto, de contexto que envolve dentre outros aspectos, fenômenos naturais e sociais e variáveis socioeconômicas. $\mathrm{Na}$ questão 8 podemos identificar situações do cotidiano, bem como variáveis técnico-científicas, e, por fim, a questão 9 apresenta situação de contexto com base na produção de alimentos e na distribuição de renda, caracterizando-se, portanto, pela análise de variáveis socioeconômicas e também por exigir do avaliando uma elaboração de proposta de intervenção na realidade.

Concluindo, destacamos nesta etapa de nosso trabalho o fato de que os documentos oficiais analisados orientam os currículos para a contextualização do ensino tomando por base, principalmente, os universos do trabalho e da cidadania, mas também, como reforçado 
pelo novo ENEM, os universos da cultura, da tecnologia e da ciência. As orientações claras e objetivas contidas nesses documentos quanto a alguns procedimentos esperados, esbarram, todavia, em equívocos que remetem o ato de contextualizar a situações de cotidiano que pouca ou nenhuma relação estabelecem com elementos esperados. Tal constatação, que pudemos perceber a partir da análise de alguns exemplos de questões presentes em exames oficiais e/ou concursos, nos remete a refletir sobre alguns aspectos.

O primeiro aspecto que queremos destacar diz respeito à possibilidade de buscar elementos do cotidiano que possam compor contextos voltados para o universo do trabalho e da cidadania. A validade da composição de contextos com tais objetivos não exclui, de forma alguma, a possibilidade de concentrar o foco da contextualização na interdisciplinaridade ou na transdisciplinaridade, de forma que o trabalho e a cidadania sejam as inspirações para a composição do contexto que nos interessa a cada momento.

Outro aspecto que ressalta da análise realizada no capítulo, e que podemos tomar como ponto de partida para nova reflexão, está relacionado à possibilidade de que as características da composição de contextos de ensino sejam, de fato, diversificadas. Em outros termos, além de contextos compostos por conjuntos de elementos interdisciplinares ou transdisciplinares, imaginamos outros, que podem ou não estar voltados para situações do universo do trabalho e da cidadania. Comentaremos sobre isso no Capítulo 4 quando então analisaremos a possibilidade da diversificação das qualidades de contextos de ensino para o caso da Matemática.

As considerações do capítulo anterior acerca dos atos de abstrair e concretizar da ação humana, e também sobre nossa concepção de como o conhecimento é construído com base na metáfora da rede de significados, nos permitirão apresentar, no capítulo seguinte, nossa compreensão acerca do significado de contextualizar o ensino, especialmente o ensino da Matemática. Nesse percurso, depararemos com duas condições necessárias à criação de contextos de ensino de conteúdos, que são as narrativas e as metáforas. 


\title{
CAPÍTUlO 3 - A CRIAÇÃo de CONTEXTOS DE ENSINO
}

\author{
Quando os contextos são deixados de lado, os conteúdos \\ estudados deslocam-se sutilmente da condição de meios para a \\ de fins da atividade docente. (Nilson José Machado)
}

\subsection{INTRODUÇÃO}

Conhecer determinado objeto requer vê-lo em suas múltiplas relações de significado, de modo que o conhecimento se configura como um feixe de relações, de toda natureza, que o sujeito constrói para o objeto. Nesse processo, o sujeito parte das protorrelações que possui ao tomar contato com o objeto para, em função das abstrações que elabora, construir novos significados, redesenhando e ampliando o feixe de relações que caracterizam seu conhecimento sobre o objeto. Sinteticamente podemos representar esse processo por três estágios, conforme discutimos no Capítulo 1.

O estágio inicial do processo refere-se ao conhecimento que se tem sobre o objeto, enquanto no estágio final este é compreendido com os novos significados a ele agregados pelo sujeito. São, portanto, dois níveis diferentes de conhecimento concreto, sendo que o elemento responsável pela passagem de um a outro, configurando estágio intermediário, é formado pelo conjunto das abstrações elaboradas pelo sujeito. As abstrações assumem, assim, papel preponderante na construção conceitual. Como afirma Machado (2009): Afinal, sem abstração não há conhecimento (p.43).

As abstrações necessárias à construção do conhecimento são realizáveis com base no conjunto de circunstâncias que envolvem a situação sobre a qual o sujeito efetua suas reflexões. Em outros termos, as características do contexto são os elementos estimuladores das abstrações, muito embora o exagero da contextuação impeça que o sujeito possa extrapolar o que apreende para além das fronteiras das circunstâncias do momento. Estamos, assim, diante de uma questão essencial que gera, simultaneamente, um sinal de alerta: contextuar é necessário, mas é preciso conter o exagero. 
Neste capítulo, abordaremos a questão essencial, comentando sobre aspectos importantes a serem considerados na formação de contextos de ensino, deixando a análise acerca da possibilidade de exageros para o final deste trabalho.

$\mathrm{Na}$ busca por justificativas teóricas deparamos com dois elementos fundamentais para a composição contextual, qual sejam, as narrativas e as metáforas, para os quais dedicamos atenção especial. Para tanto, recorremos aos estudos de Machado (2009), Bruner (2001), Goodman (1995), Popper (2009), Perrenoud (2000), dentre outros.

A noção de contexto mais veiculada relaciona-se às aplicações cotidianas dos conceitos que estão sendo estudados a cada momento. Esta é, de fato, uma das possibilidades de contextualização dos conteúdos - especialmente os matemáticos, dos quais trataremos com detalhes - mas destacamos novamente que não se trata da única via possível para a formação do conjunto de circunstâncias necessárias à realização das abstrações, e nem mesmo, em muitos casos, a mais importante. De qualquer forma, após a apresentação neste capítulo dos elementos teóricos que, a nosso ver, estruturam a composição de contextos de ensino, no Capítulo 4 analisaremos outras possibilidades de composição contextual, diferentes daquelas que priorizam as aplicações dos conceitos matemáticos em situações cotidianas.

\subsection{ConteXtos E MUNDOS}

A associação entre os significados atuais e os destacados na origem do termo nos mostra que o ato de contextualizar (ou de contextuar) determinado evento implica em alguns aspectos. Um desses aspectos diz respeito a impor que o evento se desenvolva sobre uma rede de circunstâncias que, de alguma forma, estejam relacionadas às características dos objetos que o constituem. Tais circunstâncias incluem, por exemplo, a caracterização dos personagens e a formação do ambiente físico em que eventualmente ocorre alguma ação. Inclui ainda a caracterização das relações entre personagens e entre personagens e espaço físico, relações estas de natureza psicológica, histórica, social, econômica etc., todas elas viventes na cultura dos sujeitos envolvidos.

Outro aspecto acerca da composição de um contexto diz respeito aos instrumentos linguísticos utilizados. A composição dessa rede de circunstâncias é realizada através da mobilização de recursos de um ou mais tipos de linguagem. No caso geral, mas não o único, a construção de um contexto se viabiliza sobre o desenrolar de um texto ou de um conjunto de 
textos, de modo bastante semelhante ao que ocorre com a elaboração de uma narrativa, em que a atribuição de significados aos elementos que a compõem se efetua a partir do discurso. Contextuar e narrar são atos indissociáveis no discurso e na ação.

No âmbito da filosofia contemporânea, localizamos em Popper (2009), a seguinte definição de contexto: entendo por “contexto” um conjunto de pressupostos básicos, ou princípios fundamentais - ou seja, uma textura intelectual (p. 70)

Em sua obra, Popper discursa em defesa da ciência e da racionalidade e contra as ideias constituintes do relativismo, que é, para ele:

[...] doutrina segundo a qual a verdade é relativa à nossa formação intelectual que, supostamente, determinará de algum modo o contexto dentro do qual somos capazes de pensar: a verdade mudaria assim de contexto para contexto. (2009, p. 68)

No âmbito analisado por Popper, a noção de contexto está relacionada ao conjunto de elementos que caracterizam a cultura de determinado agrupamento intelectual, que se define, por exemplo, a partir de questões geográficas, políticas, ou científicas.

Em seus argumentos, Popper critica aquilo que se caracteriza como o "mito do contexto", ou seja, a posição relativista segundo a qual,

A existência de uma discussão racional e produtiva é impossível, a menos que os participantes partilhem um contexto comum de pressupostos básicos ou, pelo menos, tenham acordado em semelhante contexto em vista da discussão (2009, p. 69)

e que implicaria na inexistência de verdade absoluta ou objectiva, mas sim uma verdade para os Gregos, outra para os Egípcios, outra ainda para os Sírios etc.(2009, p. 86)

Analisando a evolução da ciência, especialmente as concepções acerca dos modelos de nosso sistema solar, dos gregos a Newton, Popper defende a posição de que as contradições inerentes ao método científico e ao choque de culturas, foram fatores determinantes para a formação dos conceitos científicos.

A ciência humana começou pela tentativa ousada e esperançosa de compreensão do mundo em que vivemos. [...] Tudo isto, proponho, é resultado de um choque de culturas, ou choque de contextos, que levou à aplicação do 
método da discussão crítica à criação de mitos - às nossas tentativas de compreender e explicar o mundo e a nós próprios. $(2009$, p. 84)

As limitações às discussões críticas impostas pelas diferentes condições culturais idioma, costumes, etc. - para Popper, assemelham-se a prisões em que os envolvidos se escondem a fim de não compreender e/ou aceitar que as diferenças não são impeditivos ao acordo e à superação das divergências. Se nos esforçarmos, segundo ele, poderemos transcender a nossa prisão através do estudo das características culturais de nosso "oponente" e da comparação entre seus elementos e os nossos, vencendo, dessa forma, o "mito do contexto":

As prisões são os contextos. E aqueles que não gostam de prisões opor-se-ão ao mito do contexto. Acolherão de bom agrado a discussão com alguém de outro mundo, de um outro contexto, pois isso dá-lhes a oportunidade de descobrir as amarras que até aí não sentira, ou de as quebrar e assim superarse a si mesmo. $(2009$, p. 98$)$

A "prisão do contexto", citada por Popper, permite conjecturar, com base na questão pedagógica, que se os contextos são, em certa medida, inevitáveis, é preciso determinar maneiras de transcender a eles, afrouxar suas "amarras", elaborar novos contextos, imaginar, produzir, enfim, um conjunto de novas imagens e significados para os elementos que os constituem.

Em sua obra Modos de fazer mundos, Goodman (1995) metaforizando a constituição das verdades humanas, avaliza a possibilidade de que as certezas científicas possam depender do conjunto de elementos que determinam o contexto. Assim, embora parta de compreensão semelhante à de Popper acerca dos elementos que determinam um contexto, Goodman parece discordar de Popper quando escreve:

Se eu perguntar pelo mundo, pode oferecer-se para me dizer como ele é de acordo com um ou mais quadros de referência; mas se eu insistir em que me diga como ele é fora de todos os quadros de referência, o que pode dizer? Estamos confinados a modos de descrever o que quer que seja descrito. (1995, p. 39)

Posições racionalistas e relativistas, como as defendidas respectivamente por Popper e Goodman, parecem concordar com a relação intrínseca entre os elementos formadores da 
cultura dos sujeitos e os contextos em que constroem seus conhecimentos. Se Goodman admite a impossibilidade de compreender o mundo sem a fixação de quadros de referências, que podemos entender como um conjunto dos elementos culturais, conforme citação anterior, Popper, de modo explícito, relaciona diretamente cultura a contexto quando formula que nossa civilização ocidental advém do choque, ou confronto, de diferentes culturas e, por conseguinte, do choque, ou confronto, de diferentes contextos. (2009, p.75)

Bruner (2001) reforça a proposição de que a aprendizagem e o pensamento exigem viabilizar-se sobre a via de contextos culturais, no sentido de que apenas sobre tais contextos os significados conceituais podem ser produzidos, reconhecidos e incorporados pelo sujeito, conforme escreveu:

Produzir significado envolve situar encontros com o mundo em seus contextos culturais apropriados a fim de saber "do que eles tratam". Embora os significados estejam "na mente", eles têm suas origens e sua importância na cultura na qual são criados. (p. 16)

Assumimos, portanto, a responsabilidade dos elementos culturais na formação dos contextos em âmbitos que vão além da esfera educacional, mas que a ela também se aplica. Dessa forma, consideramos contextos significativos aqueles que se estruturam a partir da prototeia de conhecimentos que os alunos possuem e que estimulam a ampliação dessa teia a partir do estabelecimento de novas relações entre significados conceituais. Os elementos componentes da cultura dos indivíduos constituem as condições primárias a serem obedecidas, para que contextos elaborados com fins pedagógicos possam ser considerados significativos.

Popper e Goodman defendem posições diferentes em relação à importância dos contextos na interpretação das realidades vividas e por viver de agrupamentos sociais, sejam eles de natureza científica, política, étnica etc. Não é proposta deste trabalho analisar as características de tal controvérsia, que nos remeteria ao estudo aprofundado das correntes filosóficas identificadas pelo racionalismo e pelo relativismo. Todavia, julgamos importante destacar a concordância de Popper, Goodman e também Bruner quanto ao papel da cultura dos sujeitos na formação dos contextos nos quais se constituem as características sociais dos grupos, extrapolando que, apenas a partir do reconhecimento destas características poderemos elaborar contextos de ensino de fato significativos para o grupo ao qual se destina. Com base nisto, vamos destacar alguns elementos da obra de Goodman (1995) que julgamos importante, 
dada a sua convergência com as características necessárias à construção de contextos para o ensino de conteúdos.

Em sua proposta de feitura de mundos, que podemos associar às características da formação dos contextos, Goodman destaca cinco aspectos: Composição e decomposição, Enfatização, Ordenação, Supressão e completação, e Deformação.

Quanto ao primeiro aspecto, Composição e decomposição, Goodman destaca a presença das ações de separar, reunir, dividir, analisar etc., na elaboração de contextos, enfatizando ainda elementos que permitem ligações entre estas ações: Tal composição ou decomposição é normalmente efectuada, ajudada ou consolidada através da aplicação de etiquetas: nomes, predicados, gestos, imagens etc. (1995, p. 44)

Observemos que as "etiquetas" assinaladas por Goodman constituem conjunto de elementos próprios da cultura dos sujeitos. Dessa forma, decompor, organizar, reorganizar e compor são ações explicitamente presentes na formação de contextos, organizadas com base no respeito às características culturais do grupo social.

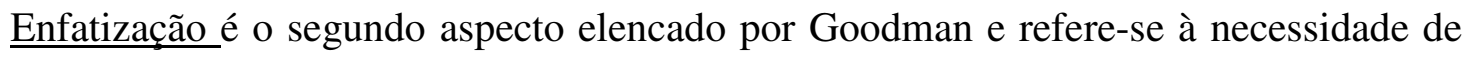
destacar os elementos considerados importantes dentre aqueles do conjunto total de características do agrupamento analisados. De forma semelhante à utilização de um mapa, a partir do qual percebemos os destaques atribuídos a limites geográficos, relevos etc., também na formação de contextos faz-se necessário ordenar a importância de elementos constituintes, com base em algum critério de julgamento, selecionando e atribuindo maior ou menor importância àqueles que venham compor o quadro de referência contextual. Também nesse aspecto, detectamos em Goodman a preocupação com a influência dos aspectos culturais na seleção e organização dos pontos de referência:

Tal como acentuar todas as sílabas é não acentuar nenhuma, assumir todas as classes como espécies relevantes é não assumir nenhuma como tal. [...]. Tal como uma esmeralda verde e uma esmeralda verdul, mesmo que sejam a mesma esmeralda, um Cristo de Piero della Francesca e um de Rembrandt pertencem a mundos organizados em espécies diferentes. (1995, p. 48)

O terceiro aspecto destacado por Goodman é a Ordenação, que se refere à maneira como os padrões que caracterizam os mundos, ou contextos, podem ser compreendidos a 
partir de uma classificação que considera elementos temporais e espaciais, ou seja, em suas palavras: A ordem inclui periodicidade tal como proximidade (1995, p. 50).

As condições em que são estabelecidas ordenações determinadas, temporais ou espaciais, dependem, assim como os demais aspectos, das características culturais, às quais Goodman se refere metaforicamente da seguinte maneira:

Tanto quanto a natureza das formas muda em diferentes geometrias, assim os padrões percebidos mudam em diferentes ordenações; os padrões percebidos na escala dodecafônica são absolutamente diferentes daqueles percebidos na tradicional escala de oitavas [...] (1995, p. 50)

Supressão e completação é o penúltimo aspecto apontado por Goodman e que podemos compreender como a possibilidade de que contextos sejam constituídos a partir de outros contextos, por movimentos de exclusão de categorias de um deles para a inclusão das novas categorias de outro. Exclusões e inclusões são ações corriqueiras quando consideramos contextos construídos especialmente para o desenvolvimento de atividades pedagógicas, como é o caso, por exemplo, daqueles em que nos baseamos para apresentar aos estudantes conceitos de geometria. Nesses casos, podemos imaginar conjuntos de circunstâncias pertinentes para a composição de um contexto apropriado aos estudantes que se iniciam no conhecimento geométrico, e outros conjuntos de circunstâncias, ou contextos, compostos a partir de alguns elementos do conjunto antigo e também de outros, que ofereçam significados pertinentes a estudantes de maior grau de escolaridade. Os critérios de seleção para a exclusão ou para a completação de elementos nesses conjuntos de circunstâncias obedecem às características da cultura dos sujeitos envolvidos. Sobre isso, escreve Goodman: E mesmo no interior do que percebemos e recordamos, descartamos como ilusório ou insignificante o que não pode ser enquadrado na arquitetura do mundo que estamos a construir. (1995, p. 52)

Por fim, Goodman aponta o quinto aspecto que considera importante na constituição de um mundo: a Deformação. Esse aspecto revela a possibilidade de compormos um novo contexto a partir de outro, antigo, sobre o qual projetamos situações e as adaptamos às exigências que desejamos para o novo contexto. Assim, por exemplo, podemos extrair de situações importantes da História as condições para elaborarmos roteiros de narrativas fabulosas que transportem os significados conceituais que pretendemos apresentar aos nossos alunos. Como escreve Goodman: Os caricaturistas passam frequentemente da sobreenfatização para a distorção real. Picasso, partindo de Las Meninas, de Velásquez, e 
Brahms, partindo de um tema de Haydn, trabalham variações mágicas que equivalem a revelações. (1995, p. 54)
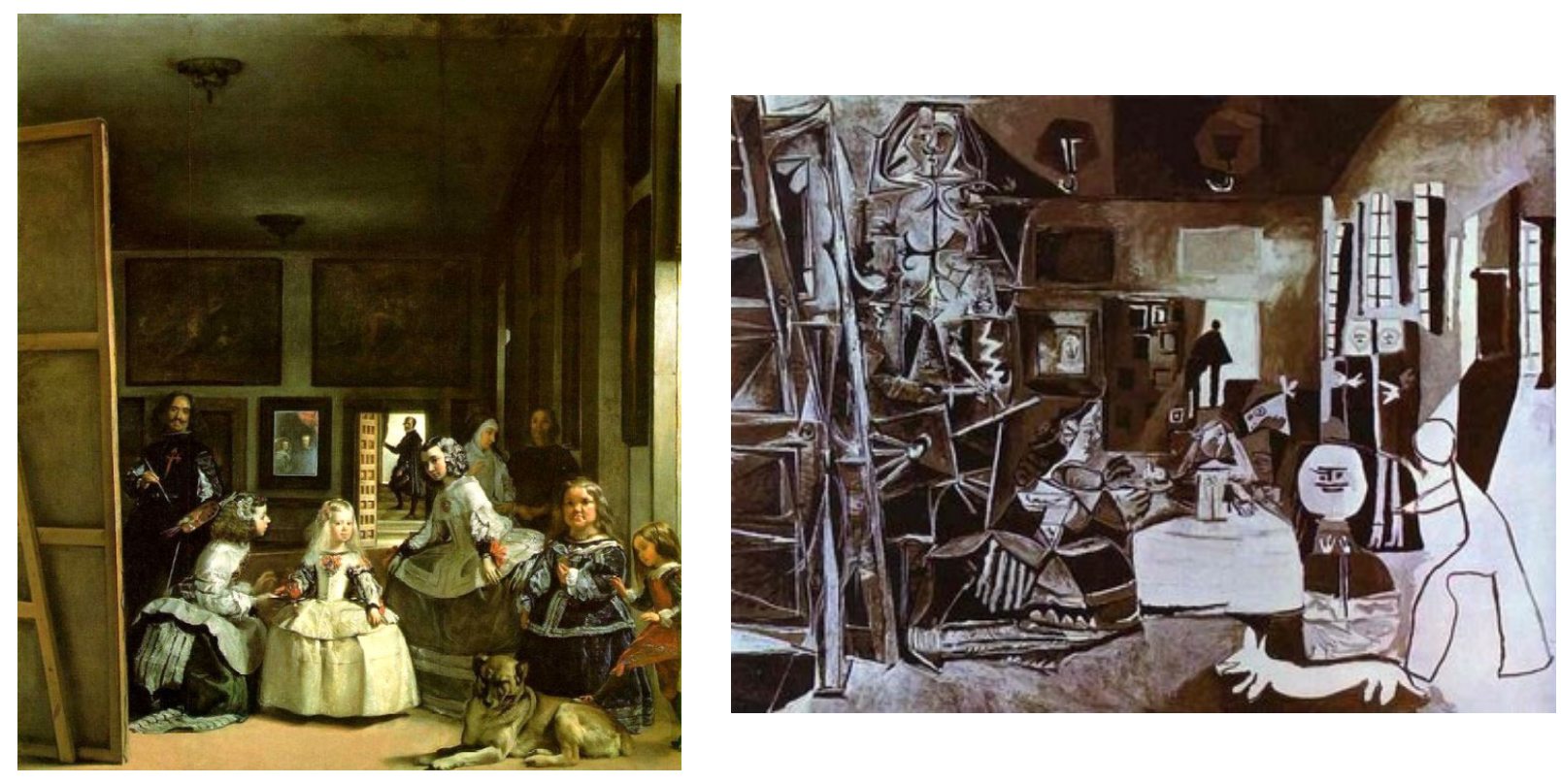

As meninas, obra-prima de Diego Velásquez, pintada em 1656, atualmente exposta no Museu do Prado, Madri. Ao lado, a composição de Picasso, que é uma das reinterpretações da obra de Velásquez, produzida na década de 1950.

O aspecto da deformação remete a uma importante tarefa do professor: a reinterpretação do real tendo em vista a construção de contextos para o ensino de conteúdos disciplinares. Em outras palavras, na elaboração de um contexto, o professor recorre às características culturais do grupo ao qual pertence e as adapta, reconfigura, reinterpreta, a fim de transportar de modo mais efetivo os significados conceituais aos seus alunos.

Os aspectos destacados por Goodman - Composição e decomposição, Enfatização, Ordenação, Supressão e completação, e Deformação - a serem considerados na composição dos contextos, no âmbito da filosofia, podem contribuir para a reflexão acerca da constituição de contextos significativos para o ensino, não apenas da Matemática. Muito embora, adiante, no Capítulo 4, analisaremos exemplos de contextos constituídos para o ensino de conteúdos matemáticos, cabe, por ora, apresentarmos um caso dessa natureza no qual possamos identificar a presença dos aspectos destacados por Goodman.

Consideremos os conceitos relacionados ao estudo das probabilidades, presentes nos currículos de Matemática do Ensino Médio. A apresentação aos alunos dos conceitos desse importante tema pode ser feita com base em um percurso estruturado sobre o contexto dos 
jogos de azar. Sabemos que a origem do estudo das probabilidades esteve aliada à análise das chances, maior ou menor, de ocorrência de determinado jogo no lançamento de dados e/ou na distribuição das cartas de baralho. Recuperar os primórdios da correspondência trocada entre Pascal e Fermat, no século XVII, adaptando-a a situações atuais e pertinentes à cultura do grupo social ao qual pertencem os alunos exige cumprir alguns dos aspectos arrolados por Goodman. Comecemos pelo aspecto da enfatização.

Desejando apresentar aos alunos as principais ideias que envolvem o cálculo probabilístico, caberá ao professor identificar uma ideia principal, que enfatizará na introdução do conceito. Suponhamos que, por exemplo, a ideia selecionada seja a da multiplicação de probabilidades de dois eventos independentes. O aspecto da enfatização estará presente, portanto, na seleção do conceito introdutório.

Feita a seleção do conceito introdutório, o passo seguinte pode ser a ordenação dos demais conceitos, de acordo com a composição contextual que o professor imagina. Podemos supor, por exemplo, que o conceito inicial do produto de probabilidades precederá o cálculo da probabilidade da reunião e/ou da intersecção de eventos que, por sua vez, precederá o estudo das probabilidades associadas a situações envolvendo raciocínio combinatório etc.

Voltemos à seleção do conceito inicial, do produto de probabilidades. Nesse caso, entra em cena o aspecto da supressão e completação, pois o professor precisará conceber situação contextual que, apesar de basear-se na realidade histórica do surgimento do conceito, exigirá a eliminação da narrativa de passagens conhecidas para a introdução de outras, adaptadas à realidade atual. Assim, serão desprezadas passagens do contexto histórico original e, a partir da inclusão de novos padrões, será formado outro contexto, com objetivos pedagógicos, construído, portanto, a partir de pressupostos semelhantes ao contexto original.

Cumpridos mentalmente os demais estágios, o professor poderá, então, propor a uma dupla de alunos a simulação de um jogo de par ou ímpar, na qual o vencedor será aquele que vencer, primeiro, certo número de partidas. O cálculo da probabilidade de ganho final para um dos jogadores, após cada rodada, envolverá o produto das probabilidades. O professor poderá desafiar seus alunos a efetuarem os cálculos após cada rodada, de forma a induzi-los para a forma geral desse tipo de cálculo. Ao realizar proposta semelhante a esta, recuperando, de certa forma, passagens históricas e adaptando-as, o professor estará percorrendo o aspecto destacado por Goodman quanto à deformação, visto estar compondo um contexto a partir de 
outro, do qual selecionou as categorias que interessavam e as caracterizou de modo diferente, visando seu objetivo atual.

Enfim, o professor construiu seu contexto para a apresentação do cálculo das probabilidades. Para executá-lo, entra na sala e relata a seus alunos, mesmo que brevemente, o fato de que as probabilidades foram, inicialmente, apenas destinadas ao cálculo das chances de um jogador neste ou naquele jogo, mas que com o advento da nova Física, a partir do final do século XVIII até nossos dias, o cálculo probabilístico, associado à estatística, converteu-se em ferramenta indispensável a toda e qualquer área do conhecimento, como, por exemplo, Psicologia, Economia e Física. Em seguida, convida dois alunos a participarem de uma competição de par ou ímpar em "melhor de 7". O restante da classe pode também dividir-se em duplas e competirem em paralelo. Quando forem decorridas três rodadas apenas, com o placar podendo apontar $3 \times 0,2 \times 1,1 \times 2$ ou $0 \times 3$, o professor convoca seus alunos a calcularem a chance percentual de cada jogador vencer a partida, ou seja, atingir primeiro as quatro vitórias. Os cálculos assim feitos servirão para o professor introduzir a multiplicação de probabilidades e, a partir daí, seguir na apresentação dos conceitos que ordenou em seu planejamento.

Para explicitar melhor a perspectiva do professor na condição de personagem fundamental na elaboração dos contextos de ensino, no item seguinte deste capítulo nos remeteremos aos estudos de Machado (2009), a respeito das competências dos professores. Em nossos argumentos, relacionaremos os aspectos destacados por Goodman para a caracterização de contextos com as condições que Machado aponta para uma competente atuação do professor, visto ser este o agente principal da concepção, criação e aplicação de situações que objetivam estimular a aprendizagem dos conteúdos próprios de sua disciplina.

\subsection{O PROFESSOR E OS CONTEXTOS}

De início, destacamos novamente a perspectiva de que a constituição de contextos de ensino, compostos por elementos estimuladores de relações entre significados conceituais, é uma das condições principais para a tarefa docente. Tal ação, própria do âmbito das disciplinas de cada área do conhecimento e, para além disso, a ser perseguida em âmbitos que extrapolam as barreiras disciplinares, permite a constituição dos mapas de relevância nos 
quais são destacados os conteúdos, os significados e os percursos que relacionam uns e outros de modo a propiciar o aprendizado.

Embora estejamos, neste momento, salientando a importância dos contextos de ensino, parece-nos claro que a restrição dos estudos unicamente a um grupo de elementos característicos pode valorizar, por extremo, os significados associados às aplicações conceituais, internas ao contexto, caso não se evidencie a possibilidade da ampliação dos significados para além das fronteiras estabelecidas pelo contexto. Dessa forma, como analisaremos adiante neste trabalho, a construção do conhecimento sobre determinado grupo de conteúdos exige o rompimento das amarras do contexto a fim de que o estudante possa consagrar a universalidade daquilo que apreende. Por ora, comentaremos as competências exigidas dos professores na criação dos contextos que adotam para o ensino dos conteúdos, como também as competências que podem ser desenvolvidas por seus alunos.

No item anterior a este capítulo analisamos os elementos destacados por Goodman para a formação dos mundos e os associamos à formação de contextos de ensino. Retomando, são estes os cinco elementos: Composição e decomposição, Enfatização, Ordenação, Supressão e completação, e Deformação. A mobilização de recursos para a constituição de contextos com base nos elementos apontados por Goodman é tarefa do professor competente, no significado do termo apontado por Perrenoud (2000), ou seja, que demonstra capacidade de mobilizar diversos recursos cognitivos para enfrentar um tipo de situação (p. 15).

Machado (2009) fornece, a nosso ver, importantes referências para a ação docente quando aponta um conjunto de competências a serem mobilizadas por professores no sentido de, em correspondência, promoverem o desenvolvimento de determinadas competências por parte de seus alunos. A análise das características desses grupos de competências, à luz dos elementos apontados por Goodman, pode permitir a formação de amplo conjunto de circunstâncias fundamentais à criação de contextos. Ou seja, trata-se da constituição de contextos epistemológicos que orientem a criação de contextos pedagógicos. Comecemos pelo objetivo final do processo educativo, isto é, o desenvolvimento de competências pelos alunos que vivenciam as condições que lhes são apresentadas pelo contexto de trabalho. 


\subsubsection{COMPETÊNCIAS DISCENTES}

O esquema seguinte, retirado de Machado (2009) apresenta seis competências a serem desenvolvidas pelos alunos:

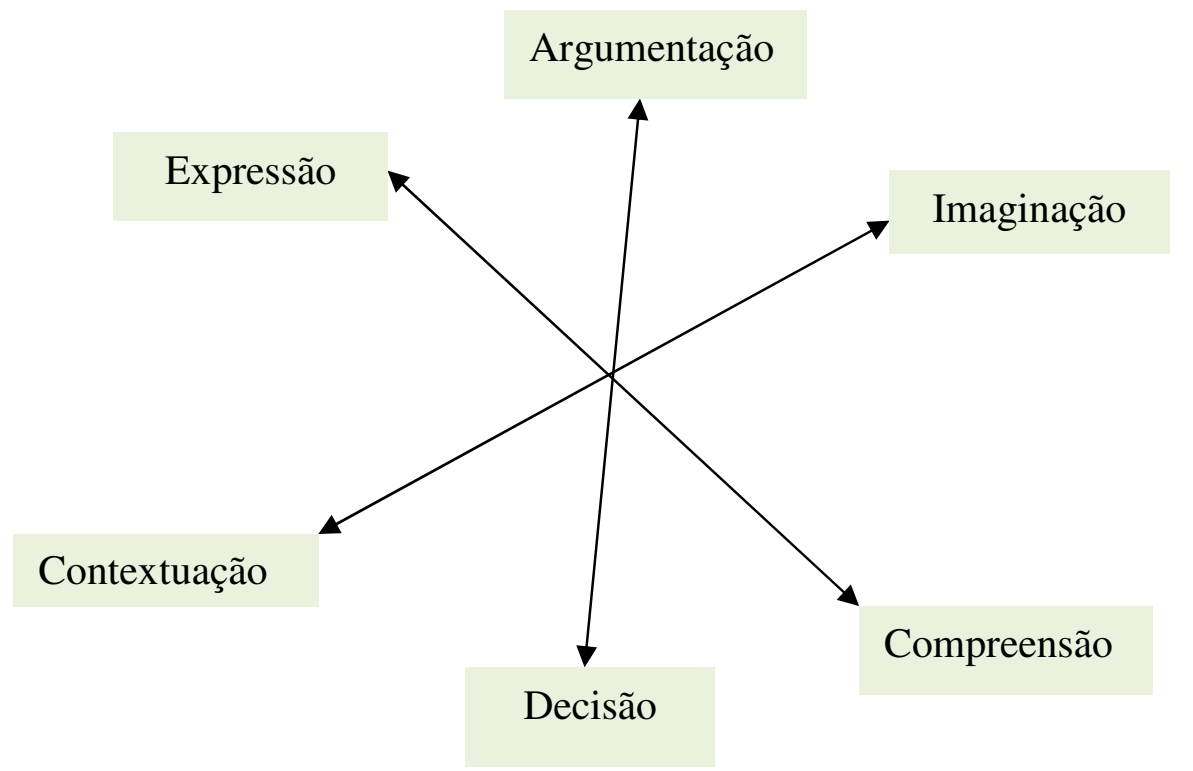

Segundo o autor, as competências organizam-se em três eixos. Nos extremos de cada eixo destacam-se duas competências complementares, no sentido de que os elementos de cada par podem e devem se desenvolver em conjunto. Analisemos brevemente cada par.

O primeiro par no qual salta aos olhos a integração entre seus elementos é o par de competências expressão-compreensão. Saber se expressar é condição primeira do sujeito que busca comunicar-se, transmitir suas opiniões, dizer ao outro um pouco de si. Assim, expressão é base de nossa pessoalidade, efetivada em vários formatos e em variadas linguagens; por meio dessa competência somos vistos, entendidos, analisados, enfim, reconhecidos. Segundo Machado (2009), existe um relativo consenso quanto ao fato de que, quando se tem algo a dizer, quanto mais rica é a capacidade de expressão, mais competente é a pessoa (p. 53).

Se a expressão é reduto de nossa pessoalidade, a capacidade de compreensão é a competência que nos obriga a olhar o outro, e que nos impele à comunicação. Quem se expressa quer ser notado, e quem nota quer compreender. Assim, expressão sem compreensão, e vice-versa, ou ainda o eu sem o outro, são alternativas que não se configuram em ações essencialmente humanas e, portanto, não se coadunam com o saber ouvir, escutar, 
refletir, discutir, considerar, reconsiderar, concluir e sintetizar. Quem se expressa, dirige-se a alguém, busca a ação comum, a comunicação. (Machado, 2009, p. 53).

O ato da expressão está dialeticamente relacionado ao da compreensão, e ambos, de certa forma, estruturam outro par de competências: argumentação e decisão.

Se não é possível, a quem quer que seja, demonstrar capacidade de expressão a respeito de determinado tema sem que tenha construído anteriormente conhecimento sobre ele, podemos aplicar raciocínio análogo para o caso em que estão em jogo as capacidades de argumentação e de decisão. Nessas situações ressalta-se novamente a importância do aprendizado de conteúdos enquanto meios ou recursos para o desenvolvimento de competências, pois uma argumentação se constrói a partir de encadeamentos lógicos, coerentes, conclusivos, importantes no aprendizado de todas as disciplinas curriculares. Argumentar exige que seja dado um salto adiante; exige decidir. Esta é a capacidade que se busca desenvolver: argumentar para decidir. Nesse sentido, escreve Machado (2009):

Após analisar todos os ângulos, todos os aspectos envolvidos, é muito
importante decidir-se a respeito da questão em pauta, saindo da cisão que a
observação dos diversos lados da questão propicia, e chegando à decisão, ao
final da cisão [...] (p.55).

As duas competências esperadas dos alunos, limites do terceiro eixo de competências apontado por Machado (2009), remetem diretamente ao tema deste trabalho. Tratam-se das capacidades de contextualizar e de $\underline{\text { imaginar. }}$

Espera-se que os alunos sejam capazes de percorrer traçados entre significados dos conceitos que estão estudando, relacionando-os, interpretando-os, situando-se, dessa forma, como agentes do contexto que lhes foi oferecido. A ação discente confere significado aos elementos contextuais. Sendo assim, espera-se também que os alunos que vivenciam o processo estimulado pelo professor possam dar vida aos conceitos disciplinares, de modo a não os confinarem em si mesmos, deslocando-os para auxiliá-los na compreensão de exemplos, aplicações e situações de outras origens e naturezas, diversas daquela que lhes permitiu tomar contato inicial com o conceito. 


\subsubsection{COMPETÊNCIAS DOCENTES}

Destacadas as competências desenvolvidas pelos alunos, passemos a relacioná-las às competências esperadas do professor em sua ação docente, conforme aponta Machado (2009). De fato, devemos esperar dos professores a mobilização das mesmas competências apontadas para os alunos, uma vez que sua prática se reveste cotidianamente de ações como expressar, compreender, argumentar, decidir, contextuar e imaginar. Todavia, o exercício do magistério exige a mobilização de competências específicas de tal ação, mobilizadas no sentido da concepção, organização e execução do planejamento didático-pedagógico. Observemos o esquema com as seis competências dos professores destacadas por Machado (2009):



Nesse esquema, de forma análoga à realizada quando da análise das competências a serem desenvolvidas pelos alunos, Machado(2009) agrupa as competências dos professores em três eixos, sendo que os extremos de cada eixo envolvem competências complementares da ação docente. Analisemos brevemente cada uma delas, começando pelo eixo autoridadetolerância.

Inúmeras são as oportunidades em que se exige do professor o exercício de sua autoridade, sendo a principal aquela em que apresenta os contextos de trabalho a seus alunos e os conduz pelos percursos que são estabelecidos. Cabe ao professor, nesses momentos, estimular ou refrear, alimentar ou combater, sempre por meio da palavra, da argumentação, 
do convencimento, sempre assumindo a responsabilidade pelos resultados obtidos (Machado, 2009, p. 77).

A autoridade do professor junto a seus alunos está, portanto, relacionada à sua capacidade de convencimento por argumentação, por declaração constante dos objetivos das atividades que organiza e propõe, por negociação permanente de suas intenções didáticopedagógicas e pela justiça que transparece nas avaliações que realiza. Há sempre o risco de que tais condições, que são procedimentos explícitos de exercícios de autoridade, convertamse em práticas autoritárias, pela ausência ou pela extinção do diálogo e da negociação. Autoritarismo, diferentemente do exercício da autoridade, caracteriza-se pela imposição de preceitos com a ausência da argumentação e do convencimento. O desvio da autoridade para um extremo conduz ao autoritarismo, para o comando que se obedece mas não se respeita. Já o desvio da autoridade para o outro extremo conduz à prevaricação, ou seja, à autoridade que, embora legítima, não se exerce e, por isso mesmo, também não é reconhecida.

Dialogar, argumentar, ouvir, convencer e decidir são posturas inerentes à ação do professor que exerce com consciência sua autoridade, e são também ações necessárias ao exercício de outra competência docente, sem a qual não se pode conceber a autoridade: tratase da tolerância.

No âmbito de processos educativos, mas não apenas neles, negociar para convencer exige ser tolerante, pois em primeira instância, exige justificar os procedimentos esperados dos alunos prestes a se envolverem nos percursos traçados sobre o contexto escolhido. Mais do que isto, a prática da tolerância exige saber ouvir e argumentar com aqueles que, por qualquer motivo expresso, porém não justificado, tencionem opor-se aos critérios estabelecidos para as atividades. Dessa forma, autoridade e tolerância, condutas indissociáveis da ação do professor, estão diretamente relacionadas à ação objetiva de condução dos alunos por entre os percursos contextuais, através da orientação, da indicação dos caminhos, da correção de rotas, da avaliação dos procedimentos etc.

Conduzir os trabalhos com autoridade e tolerância exige que tenham sido estabelecidos os contextos sobre os quais serão desenvolvidas as atividades. Na criação desses contextos o professor precisará mobilizar outros dois pares de competências. Por um lado, mapear e tecer, e por outro, mediar e fabular. Inicialmente comentaremos sobre o primeiro par, mapear e tecer, ações imprescindíveis na constituição de um contexto pedagógico. 
Uma das definições de contexto afirma que "é o conjunto de circunstâncias e detalhes que acompanham um fato e contribuem para aclará-lo"8. Partindo desta definição, podemos conjecturar que, para a constituição de um contexto, precisamos considerar as características que seus elementos possuem quando observados para além do contexto, ou seja, precisamos compreender, da maneira mais ampla possível, as relações de significado que se estabelecem entre os objetos a fim de selecionar aquelas que, particularmente, interessam ao conjunto de relações que caracterizam o contexto adotado. Quer dizer, precisamos observar e compreender o todo para que seja possível selecionar uma parte que traduza significância aos objetos constituintes. Tais ações podem ser traduzidas nas duas competências apontadas anteriormente, ou seja, mapear e tecer.

Um mapa, no sentido usual, cartográfico, oferece condições para que seja visualizada toda uma região. Quem olha um mapa o faz com objetivo de identificar elementos que interessam, sejam eles, por exemplo, uma cidade, uma estrada, um relevo etc. Tratando-se do ato de mapear no sentido pedagógico, ou seja, no sentido de identificar significados importantes para a constituição do contexto que interessa no momento, cabe ao professor estabelecer o grau da lente com que observará as relações existentes entre os elementos que considera. Lentes de grau elevado servirão para destacar relações de diferentes grandezas e importâncias, desde as mais simples até as mais complexas. O contrário ocorrerá se a observação do mapa for realizada com uma lente de pequeno grau, capaz de revelar apenas as relações aparentemente mais gerais e significativas. A ação docente, neste caso, consiste em mapear relevâncias a partir do grau da lente que estabelece para a identificação dos significados dos objetos que considera importantes para a formação de um contexto de ensino.

Alguns elementos apontados por Goodman na constituição dos mundos parecem convergir em significado à ação de mapear, destacada por Machado. Vejamos a seguinte afirmação de Goodman (1995) acerca do aspecto da enfatização:

Algumas espécies relevantes de um mundo, em vez de estarem ausentes do outro, estão presentes como espécies irrelevantes; algumas diferenças entre mundos não são tanto diferenças de entidades compreendidas, mas sim de ênfase ou de acentuação, e estas diferenças não são menos importantes. (p. 48)

As espécies relevantes em um mundo que, embora presentes em outro, são neste consideradas irrelevantes, podem ser associadas aos significados conceituais que destacamos

\footnotetext{
${ }^{8}$ Enciclopédia Delta Larousse, 1974.
} 
na elaboração de um contexto, mas que não consideramos em outros. Assim, a ênfase atribuída a este ou àquele significado (espécie), neste ou naquele contexto (mundos), dependerá da escala adotada pelo professor na construção de seu mapa de relevâncias. A ação esperada do professor em mapear compreende, dessa forma, o aspecto da enfatização, mas não apenas este.

Sob certo ponto de vista, o ato de mapear pode ser associado a outros aspectos apontados por Goodman (1995) para a composição de um universo de significados. Composição e decomposição, por exemplo, são ações vinculadas ao mapeamento, uma vez que, para identificar e selecionar relevâncias, o professor muitas vezes é estimulado a partir, agrupar, repartir, reagrupar classes de condições, buscando harmonizar o contexto que organiza às características apropriadas a determinado segmento de ensino, a turmas específicas, etc.

Também o elemento supressão e completação encontra correspondência na competência de mapear, esperada do professor. Sobre tal elemento, Goodman (1995) escreve: O cientista não é menos drástico, rejeitando ou purificando muitas das entidades e eventos do mundo das coisas vulgares (p. 52).

Tal afirmativa encontra correspondência no texto de Machado (2009), quando escreve a respeito do mapear: Para tirar proveito da multiplicidade de relações entre os diversos temas, é necessário mapear o que é e o que não é relevante, tendo em vista as intenções e os projetos em curso. (p. 67)

Não há, portanto, correspondência biunívoca entre os elementos apontados por Goodman (1995) e as competências destacadas por Machado(2009) quanto à prática docente. Há, isto sim, possibilidades variadas de identificação entre as proposições de um e outro autor, de maneira que vislumbremos a possibilidade de, nelas, o professor buscar abrigo teórico seguro para a composição de contextos de ensino. Comentemos um pouco mais sobre possibilidades de associação entre elementos e competências.

Identificados os diversos significados conceituais a partir do mapeamento determinado pelo professor, torna-se necessário escolher caminhos, percursos entre os significados, de modo a relacioná-los e a compor a rede conceitual que favorecerá a construção do conhecimento dos alunos sobre o corpo de objetos de estudo. Tal é o ato de tecer; enredar significados segundo alguma ordenação com determinado objetivo. Também neste caso notamos proximidade entre as competências apontadas por Machado (2009) e o elemento da 
ordenação, destacado por Goodman (1995). A definição dessas ordenações e objetivos estará a serviço da formação do mundo, segundo Goodman, ou da constituição do contexto de ensino, segundo Machado. Ressaltemos, portanto, que grupos comuns de objetos de estudo poderão ser analisados sobre percursos diferentes, dependendo da maneira como se enredem os significados desses objetos. Espera-se do professor que identifique os objetos de estudo, destaque suas relevâncias para o momento, estabeleça as relações de significado que deseja ressaltar, teça percurso sobre tais significados, ordenando-os em conformidade com o contexto escolhido.

\subsection{CONTEXTOS E NARRATIVAS}

O terceiro eixo de competências do professor, destacado por Machado (2009), tem num extremo o ato de mediar e, no outro, o ato de fabular.

Tornou-se comum a afirmação sobre a necessidade de serem considerados os conhecimentos anteriores dos alunos. Nessa perspectiva, cabe ao professor elaborar atividades de ensino que partam das relações já conhecidas pelos alunos, a fim de ampliá-las, instituindo, a partir destas, outras relações. Se tal atitude é necessária, não é, todavia, suficiente.

Na constituição do percurso desejado sobre o contexto que escolhe, de modo a construir a rede conceitual que planeja, é necessário considerar uma série de relações que não são conhecidas pelos alunos e que, além do mais, muitas vezes não lhes são de interesse imediato. Nem por isso, no entanto, o professor deve poupá-los do contato com tais relações, mobilizando, para tanto, sua competência de argumentação. Tal processo implica na negociação de interesses - do professor e dos alunos - no sentido da busca do objetivo planejado. Esta é a tarefa do professor como mediador: conciliar seus interesses com os interesses dos alunos, com vistas a tecer a rede de significados conceituais que permitirá a construção do conhecimento projetado. Sobre a constituição das relações de significado, escreveu Machado (2009):

É fundamental, no entanto, que o professor, como um mediador, negocie com os alunos, convencendo-os da relevância das mesmas. Não se pode pretender impor a percepção: é preciso negociar a abertura dos sentidos por parte dos alunos. (p. 65) 
Um professor competente realiza mediações de interesses, no sentido de estimular os alunos para a construção de teias de significados conceituais. Convencer os alunos das relevâncias das relações que propõem implica em apresentar a eles a energia que permite unir relações, umas às outras, de maneira a constituir feixes de relações que configuram significado ao objeto de estudo. Esta energia de ligação é instaurada pela competência do professor em construir narrativas convincentes. São as narrativas, portanto, os elementos que fornecem a energia para que sejam estabelecidas as ligações entre significados conceituais, compondo, dessa forma, um percurso sobre o contexto. A desenvoltura dos alunos ao caminharem por percursos dessa natureza, elaborados a partir dos conjuntos de circunstâncias que compõem o contexto escolhido, é prerrogativa primeira da construção de uma rede de significados para os conceitos estudados. Chegamos assim à última e talvez mais importante competência do professor: construção de narrativas. Sobre isto, Machado (2009) escreve:

[...] o significado, em qualquer tema, sempre é constituído por meio de uma história, de uma narrativa bem arquitetada. (p.72)

Não são quaisquer histórias, no entanto, as que devem compor o repertório do professor: em cada uma delas, deve existir a semente de algum recado, de algum ensinamento. (p.72)

Ao compor uma narrativa com vistas a fornecer a energia de ligação para a construção de significados de um objeto ou para relacionar significados de diferentes objetos, um professor seleciona eventos e com eles compõe uma sequencia que, de alguma forma, transporta o(s) significado(s). Por exemplo, se selecionarmos apenas dois eventos, "o professor sentiu-se mal" e "o aluno saiu da sala correndo", podemos estabelecer duas sequências com significados completamente diferentes:

\section{O aluno saiu correndo da sala, o professor sentiu-se mal.}

O professor sentiu-se mal, o aluno saiu correndo da sala.

A sequência de eventos que interessa na composição de uma narrativa com fins pedagógicos, ou seja, com o objetivo de estimular relações entre significados conceituais, é selecionada a partir dos conjuntos de condições que estruturam o contexto e são, ao mesmo tempo, elementos que ajudam a estruturá-lo. Narrativas apresentam, dessa maneira, relação dialética quanto à composição de um contexto de ensino: ajudam a estruturá-lo e se estruturam a partir deles, sendo bastante difícil, na maioria dos casos, determinar o que foi 
concebido em primeiro lugar, o contexto ou a narrativa. Consideremos, por exemplo, o caso da apresentação do conceito de razões trigonométricas em triângulos retângulos, realizada normalmente no último ano do Ensino Fundamental II ou no primeiro ano do Ensino Médio.

Um dos contextos mais adotados para a introdução do tema consiste nas aplicações dos conceitos na construção civil, especialmente na construção de telhados, rampas ou outros elementos que apresentam alguma inclinação em relação à horizontal. Em relação a isto, sabese, por exemplo, que diferentes tipos de telhados apresentam diferentes graus de inclinação, dependendo de algumas circunstâncias, como o tipo de telha utilizada para a cobertura ou ainda as características do clima da região do planeta em que a construção é realizada. Na composição desse contexto o professor poderá considerar esses e outros elementos, todos com significados associados entre si, como, por exemplo: tipos de telhas, características do clima da região, dimensões do telhado, questões estéticas, destino final da construção (comércio, moradia, industrial etc.).

Podemos partir das características dos elementos que formam o contexto, para elaborar uma ou mais sequências de eventos que componham narrativa apropriada para os objetivos propostos. Um exemplo, nesse sentido, pode ser a história da residência construída em mutirão na qual, depois de habitada, percebeu-se a existência de um desagradável problema para os moradores. Toda vez que chovia, surgiam goteiras por quase toda a casa. O proprietário da residência avaliou, de início, que o problema advinha de telhas quebradas, mas sua investigação nesse sentido não resultou proveitosa, pois não havia qualquer quebra aparente.

Foi preciso refinar a pesquisa a fim de descobrir a verdadeira causa do problema: infiltração da água por entre as telhas, devido à pouca inclinação do telhado.

A evolução da narrativa poderá envolver, por exemplo, o cálculo da inclinação necessária para o tipo de telha utilizada, a discussão sobre o método que pedreiros adotam para a determinação da inclinação sem conhecerem razões trigonométricas, o tipo de telha mais apropriado a cada tipo de construção etc. De qualquer modo, são os elementos formadores do contexto que permitem ao professor a elaboração de sequências de eventos que se configuram em narrativas. Nesse caso, portanto, as narrativas são estruturadas a partir do contexto escolhido, mas também, são as narrativas que permitirão que os elementos contextuais sejam relacionados entre si, atribuindo ao contexto a sua dimensão de campo fértil para o traçado de percursos entre os significados dos elementos selecionados. 
A importância das narrativas na constituição de contextos, conforme apontado por Machado (2009), pode ser identificada com as condições destacadas por Goodman para a constituição de mundos, conforme podemos perceber pelo trecho seguinte:

Falar de conteúdo estruturado, ou de dado não conceptualizado, ou de um substrato sem propriedades, é autodestrutivo; porque o discurso impõe estrutura, conceptualiza, atribui propriedades (Goodman, 1995, p. 43)

Podemos interpretar que o "discurso que conceptualiza" a que se refere Goodman, diz respeito à forma como se encadeiam as características dos objetos na composição da sequência de eventos em que notamos sua presença, ou seja, na própria narrativa.

Outros aspectos que podemos associar à constituição de narrativas estruturantes na formação de contextos podem ser identificados na obra de Goodman (1995). Observemos o que ele escreve em relação ao aspecto da Composição e decomposição:

Muito da feitura do mundo, mas de modo algum tudo, consiste, muitas vezes de forma combinada, em separar e reunir: por um lado, em dividir totalidades em partes e em separar espécies em subespécies, analisar complexos em características componentes, traçar distinções; por outro lado, em compor totalidades e espécies a partir de partes, membros e subclasses, combinar características em complexos, e fazer ligações. (p. 44)

Cremos que as ligações entre características dos elementos, bem como a composição do todo complexo a partir do reconhecimento da simplicidade e importância de cada uma das partes, remete a uma condição inerente do discurso narrativo. Brunner (2001) apontou maneiras pelas quais a narrativa confere formas às realidades que criam e, em uma dessas maneiras, escreve sobre a particularidade genérica da seguinte forma: As narrativas tratam de detalhes. Mas a particularidade parece ser apenas o veículo da realização narrativa, pois histórias particulares são interpretadas como se se enquadrassem em gêneros ou tipos. (p.129)

Parece possível relacionar a composição e decomposição assinalada por Goodman com as particularidades destacada por Brunner, no que se refere às características das narrativas. Assim, são os detalhes acerca dos elementos que compõe a narrativa - objetos, acontecimentos, perfis etc. - que conferem intensidade e interesse à sequência de eventos, mas é a formação do todo, composto e complexo e que encadeia todos os elementos, a 
condição necessária para a transmissão da ideia fundamental prevista na elaboração da narrativa.

Contextos de ensino são formados a partir de conjunto de circunstâncias exteriores às situações de ensino, mas que guardam com elas alguma relação de proximidade, como é o caso, por exemplo, das circunstâncias que caracterizam contextos familiares, sociais, culturais, históricos e econômicos. A tarefa docente relaciona-se diretamente à identificação das circunstâncias pertinentes em cada caso e à elaboração de contextos e narrativas apropriadas em vista do objetivo proposto, qual seja, o aprendizado de conteúdos disciplinares. Nesse sentido, um caminho também possível consiste na ação do professor em organizar contextos com base em aspectos de natureza ficcional. Comentemos um pouco sobre tal possibilidade.

Discorrendo sobre a importância das narrativas na interpretação dos acontecimentos de natureza científica, Brunner alerta para interessante aspecto quando escreve [...] é que ela (a narrativa) pode ser "real” ou "imaginária” sem perder seu poder como história. Quer dizer, o significado e a referência da história guardam um relacionamento anômalo entre si. (1997, p. 47). E ainda diz que: um dos motivos pelos quais é tão difícil saber se uma história é "verdadeira” ou não é exatamente porque há um sentido em que uma história pode ser realista sem ser verídica. (2001, p.120)

Uma boa narrativa reveste-se de histórias bem contadas, histórias que não necessariamente sejam verídicas, no sentido de exigirem adequação a fatos e ações realizáveis no mundo real, mas que consigam, de modo efetivo, transportar o significado, a moral da história. Serão a sequência de eventos, a caracterização dos personagens e a maneira como as tramas serão elaboradas, independentemente de ligações com a realidade, os elementos que permitirão que isto ocorra. Narrativas fabulosas, nessa medida, são exemplo claro.

Animais se comunicam, internamente às espécies, mas não falam como os humanos. Isto não é empecilho, todavia, para que uma série de histórias povoe a mente das crianças, transportando até elas significados de naturezas diversas, histórias estas compostas por lobos que conversam com porcos, com grilos que dialogam como adultos, com serpentes que oferecem maçãs a futuros pecadores etc.

Uma vez que contextos e narrativas estruturam-se em relação simbiótica, e a falta de vinculação das histórias à realidade não é impeditivo à qualidade narrativa, parece possível conceber que contextos de ensino possam ser compostos a partir de narrativas fabulosas e/ou 
ficcionais. Há que se ter, todavia, por parte do professor, o discernimento quanto às características do aluno para o qual projeta o contexto, pois é evidente que o imaginário infantil aceita relações de significado diferentes das que podem vir a motivar adolescentes.

Especialmente no caso dos alunos das séries iniciais, é constante a prática de jogos envolvendo conceitos matemáticos. Em alguns desses casos, a obediência às regras exige a elaboração de percursos nos quais os jogadores se comportam como personagens de uma história que se constrói à medida que o jogo se desenrola. De início, todos os participantes caracterizam-se de modo único como se fossem um só personagem, mas a melhor performance de um ou outro jogador nas sucessivas etapas provoca alterações nos papéis que virão a desempenhar até o final do jogo. Visto dessa forma, determinados jogos de estratégias estruturam-se como contextos de ensino para conjuntos de conteúdos, mesmo que as regras envolvidas baseiem-se em situações fantasiosas e/ou fictícias, como aquelas que, por exemplo, caracterizam os jogos do tipo RPG (role-playing game $^{9}$ ).

Destacamos nos parágrafos anteriores as competências esperadas dos professores no exercício de sua ação docente e a importância do exercício de tais competências na criação de contextos de ensino. A importância do desenvolvimento de conteúdos com base em contextos com as características apontadas não pode, todavia, obscurecer a necessidade de rompimento das amarras do contexto, sob perigo de que significados dos objetos de estudo possam ser construídos em função apenas de condições específicas, e não possam ser extrapolados para além da construção empírica determinada, muitas vezes, pelas características do contexto adotado. Em capítulo posterior teceremos maiores comentários acerca desta questão.

\subsection{CONTEXTOS E METÁFORAS}

A noção de contexto no âmbito educacional relaciona-se a um conjunto de elementos destacados e sequenciados, que permitem a composição de um enredo no qual métodos, processos, técnicas e estratégias se desenvolvem relacionando circunstâncias - atitudes, posturas, comportamentos -, em que os intervenientes - objetos, personagens, conceitos -

\footnotetext{
${ }^{9}$ O role-playing game (RPG, traduzido como "jogo de interpretação de personagens") é um tipo de jogo em que os jogadores assumem os papéis de personagens e criam narrativas colaborativamente. $O$ progresso de um jogo se dá de acordo com um sistema de regras predeterminado, dentro das quais os jogadores podem improvisar livremente. As escolhas dos jogadores determinam a direção que o jogo irá tomar. (extraído de http://pt.wikipedia.org/wiki/Role-playing_game, em 30/11/20100)
} 
protagonizam determinado conjunto de ações. Nessa concepção, como destacamos anteriormente, as narrativas desempenham papel fundamental, na medida em que são estruturadoras das sequências de eventos ao mesmo tempo em que são estruturadas a partir de tais sequências.

O conjunto de elementos que constituem os contextos relaciona-se, especialmente, com aspectos exteriores à situação de ensino, de maneira que podemos pensar em transpor para o contexto características de manifestações existentes em espaços externos à sala de aula, como a vivência familiar, a realidade histórica, a conduta científica, entre outras. Tal transposição realiza-se pela ação do professor na seleção dos elementos e na composição das narrativas, tomando por base as relações de significados que lhe são permitidas detectar entre os conceitos que planeja desenvolver. Internamento ao contexto de ensino, os elementos que o constituem são vistos em relações que nem sempre são aquelas sobre as quais são reconhecidos fora dele. Nessa adequação dos significados conceituais à esfera de circunstâncias que caracteriza o contexto, destacamos o papel das narrativas, mas há ainda outro elemento que precisa ter sua importância valorizada, seja na própria composição das narrativas, seja na comparação entre sua função e a função dos contextos. Tratam-se das metáforas.

Metáforas são recursos linguísticos que utilizamos, por exemplo, para transmitir um pensamento que, abstrato, ainda não encontrou seu "termo", o "nome exato". Não por acaso, o pensamento científico é recorrente em metáforas. Elas são utilizadas para designar coisas que, sem serem tomadas ao pé da letra, permitem atiçar nossa capacidade intelectual para que as reconheça, ou, ainda, torne a conhecê-las, sob outro ângulo do olhar. A metáfora, como fica explícita na etimologia, implica transferir o sentido por meio da transformação de um conceito abstrato em uma imagem sensorial. Observamos exemplos dessa natureza em expressões cotidianas como "estou morto de sono", "fulano é cabeça-feita", "morro teso mas não perco a pose" e outras.

Ricoeur (2009), analisando a importância das metáforas como um dos aspectos centrais da função geral da retórica, escreve: A metáfora é uma das figuras retóricas, aquela em que a semelhança serve de razão para substituir uma palavra figurativa a uma palavra literal, perdida ou ausente. (p. 71)

A eficiência da função básica da retórica, qual seja a de convencer pela palavra, está relacionada à estratégia do orador em escolher as "melhores" palavras a serem utilizadas em 
cada momento, no sentido de persuadir o ouvinte sobre seus propósitos, sem necessidade de qualquer ação que possa exigir provas ou violências verbais. Ou seja, a retórica visa tornar mais atraente o provável. (Ricoeur, 2009, p. 71)

A função das metáforas na composição de narrativas é primordial, pois, via de regra, o arsenal de ideias do narrador é muito maior do que o arsenal de palavras de que dispõe para comunicar-se com o grau de persuasão planejado. Metáforas são instrumentos linguísticos fundamentais ao narrador para que ele possa, por intermédio de uma palavra ou expressão figurativa, transportar o amplo significado de um conceito, de uma ideia.

A propriedade principal de uma narrativa é, de acordo com Bruner (1997), sua sequencialidade inerente. Uma narrativa é composta por uma sequência singular de eventos, estados mentais, ocorrências envolvendo seres humanos como personagens ou atores (p. 46).

Os significados dos elementos constituintes da narrativa são formados a partir do papel que nela desempenham. Basta pensar, por exemplo, nos significados tão diferentes atribuídos a uma ponte nos filmes A ponte do rio Kwai, dirigido por David Lean em 1957 e em As pontes de Madison, de 1995, estrelado por Clint Eastwood e Meryl Streep. Assim, a narrativa confere significado a elementos que, fora dela, não têm vida própria, ou tem vida completamente diferente daquela que lhe é atribuída pelo enredo. Nessa composição de eventos e personagens que atribui significados a objetos determinados, ressalta a função das metáforas enquanto elementos capazes de promover a aproximação entre significados.

Narrativas fabulosas apresentam, quase todas, situações irreconciliáveis, personagens cujos desejos se realizam à custa de conflitos morais; em suma, contextos formados na perspectiva de extrapolar os limites preestabelecidos nos padrões do grupo cultural. Nesse sentido, podemos nos lembrar da Cinderela, do Gato de Botas, da Branca de Neve e de tantas outras histórias que ainda povoam o imaginário infantil. Não é à toa que, em todos esses casos, sempre há uma "moral da história", isto é, há determinado conceito, quase sempre de cunho moral, que é construído a partir do enredo da fábula. Em narrativas tão conhecidas como essas, mas não apenas nelas, identificamos a presença constante de metáforas ou de situações metafóricas como, por exemplo, no caso da avó que é engolida pelo lobo ou da abóbora que se transforma na carruagem da princesa.

Uma das funções da linguagem consiste na transmissão de significados. O uso adequado de determinado tipo de linguagem permite ao interlocutor comunicar mais ou menos facilmente os objetivos de seu discurso. Em virtude disso, por exemplo, resultados 
estatísticos são frequentemente apresentados por gráficos ou tabelas, próximos, portanto, de uma linguagem visual. Nesse caso, são tais representações que permitem acesso rápido e certeiro aos significados associados aos elementos analisados.

Uma das características da Matemática é que ela se configura em uma linguagem, com gramática e termos próprios: A Matemática quando falada parece uma linguagem natural, quando escrita faz uso variado de um sistema complexo, regulado por regras, separado da linguagem natural. (Matos et al., 1996, p. 51)

Assim, saber Matemática, em determinado âmbito, significa manipular com propriedade as regras e estruturas que organizam os conceitos nesse âmbito. Significa também, de modo análogo ao domínio da linguagem escrita, da língua materna, compreender e dominar a construção de metáforas próprias para a transposição de significados entre entes matemáticos. Assim é que, com frequência, nos deparamos com situações de ensino nas quais "uma função é uma máquina" ou na qual "resolver uma equação é o mesmo que equilibrar uma balança".

Para além de sua utilidade como uma reclassificação, a qual envolve "tratar X como se ele fosse Y", Ortega y Gasset (1987) aponta para outro significado da metáfora. Segundo o autor, a metáfora, que tem por função tradicional, de uso frequente, tornar compreensível a todos um pensamento, mediante um termo, uma palavra ou uma expressão, é também para nós, além disso, meio essencial para compreender certos objetos difíceis.

Para Ortega Y Gasset, recorremos às metáforas não apenas no exercício de comunicação com o outro, mas também no processo de transformar em acessível uma informação de qualquer natureza que nos pareça difícil de imediato. Sob esse ponto de vista, as metáforas deixam de ser exercícios de linguagem para se transformar em exercícios de pensamento, constituindo parte fundamental dos processos de construção conceitual. Especialmente sobre esse aspecto, destaca o autor:

Não são todos os objetos igualmente aptos para que os pensemos, para que deles tenhamos uma ideia parcial, de perfil bem definido e claro. Nosso espírito 
tenderá, em consequência, a apoiar-se em objetos fáceis e acessíveis para poder pensar nos difíceis e esquivos. (Ortega Y Gasset, 1987, p. 391) ${ }^{10}$.

Realizamos exercícios de pensamento especialmente quando solicitados a refletir sobre situações, eventos ou conceitos sobre os quais não construímos conhecimento anterior. Em momentos dessa natureza recorremos às metáforas como elementos auxiliares, capazes de nos fazer aproximar, pouco a pouco, do conhecimento desejado. Nesse sentido, metáforas cumprem a função das "dicas" que o participante de um jogo de "adivinhas" recebe, sucessivamente, na tentativa de, passo a passo, aproximar-se da descrição mental do objeto a ser descoberto.

Como se vê, as metáforas são importante elemento no processo de construção do conhecimento, pois:

com o mais próximo e com o que melhor dominamos, podemos alcançar contato mental com o mais remoto e arisco [...] A metáfora é um procedimento intelectual pelo qual conseguimos compreender o que se encontra mais distante de nossa capacidade de conceituar. (Ortega y Gasset, 1987, p. 391) ${ }^{11}$.

As características das metáforas, enquanto figuras de linguagem capazes de conferir significados a objetos por intermédio de imagens abstratas, e também enquanto procedimento intelectual que nos aproxima da compreensão efetiva dos significados de um objeto, encontram, a nosso ver, correspondência nas características dos contextos de ensino. Comentemos sobre esta questão.

Como afirmamos anteriormente, contextos de ensino são normalmente organizados a partir de circunstâncias externas à escola e trazidos a ela em versões elaboradas e revistas a partir da estrutura e objetivos com que o contexto foi concebido. Essa transposição exige, por um lado, a identificação dos significados dos objetos que poderão ser relacionados internamente ao contexto e, por outro lado, a adoção de metáforas que permitam ao sujeito

\footnotetext{
${ }^{10}$ Tradução nossa. No original: No son, pues, todos los objetos igualmente aptos para que los pensemos, para que tengamos de ellos una Idea aparte, de perfil bien definido y claro. Nuestro espíritu tenderá, en consecuencia, a apoyarse en los objetos fáciles y asequibles para poder pensar los difíciles y esquivos.

11 Tradução nossa. No original: con lo más próximo y lo que mejor dominamos, podemos alcanzar contacto mental con lo remoto y más arisco... La metáfora es un procedimiento intelectual por cuyo medio conseguimos aprehender lo que se halla más lejos de nuestra potencia conceptual
} 
enxergar os objetos com a nova "roupagem" que lhes será atribuída pelo papel que desempenharem nas narrativas estruturantes do contexto.

A dificuldade na compreensão dos significados de algum objeto de estudo é reflexo da distância existente entre este e o sujeito, que pode estar relacionada ao modo como se compreende a importância de um e de outro no processo de construção do conhecimento. Metodologias que valorizam em excesso, ou unicamente, o ponto de vista da Matemática enquanto ciência, com corpo de estudo e linguagens próprios, pode, especialmente em grupos de estudantes de Ensino Fundamental e Médio, favorecer um tipo de relação de sentido único entre sujeito e objeto do conhecimento. Em situações como essa pode prevalecer, sobremaneira, a importância do objeto sobre as experiências anteriores e as motivações dos sujeitos, aspecto este que não se coaduna com aqueles que concebemos para o desenvolvimento de conteúdos com base em contextos de ensino.

Nos casos em que a distância entre sujeito e objeto é grande, ou seja, quando aquilo que se deseja ensinar envolve significados aparentemente distantes da vivência e da capacidade cognitiva daquele que precisa aprender, poderemos imaginar a aproximação entre um e outro por intermédio da realização de conjuntos de situações de ensino que, respeitando as características do sujeito, reconfigure os significados do objeto, sequenciando-os em novo contexto, composto de circunstâncias recolhidas do conhecimento anterior do sujeito, e transposto para a escola. Isto é,

uma relação cognitiva na qual tanto o sujeito como o objeto mantêm sua existência objetiva e real, ao mesmo tempo que atuam um sobre o outro. Esta interação produz-se no enquadramento da prática social do sujeito que aprende o objeto na - e pela - sua atividade (Schaff, 1987, p. 75).

Contextos elaborados dirigidamente para a apresentação de conteúdos matemáticos podem permitir a aproximação entre sujeito e objeto, se criados com base no reconhecimento das vivências e conhecimentos anteriores do sujeito sobre alguns dos significados do objeto que lhe foram permitidos construir até então. Nessa aproximação, caberá ao contexto propor situações em que as novas relações a serem estabelecidas entre significados do objeto são apresentadas ao sujeito e, caberá a ele, no sentido de construí-las para si, transpor algumas características das relações anteriores para as novas, ampliando-as. A efetivação de tal procedimento, no qual relações particulares entre significados são extrapoladas para relações mais gerais, exige a utilização de metáforas, como aponta Ortega Y Gasset (1987): 
Este fenômeno universal de relação entre sujeito e objeto, que é o apreender, somente poderá conceber-se comparando-o com alguma forma particular das relações entre objetos. O resultado será uma metáfora. $(p .396)^{12}$

A respeito da composição de contextos e do uso de metáforas, consideremos um exemplo de situação de ensino no âmbito da Geometria.

Para o estudo das características das formas geométricas planas podemos adotar, por contexto, a composição e a decomposição do plano, em operações de ladrilhamento. Para recobrir uma região utilizando polígonos, será necessário conhecer as medidas de seus ângulos internos, reconhecer suas dimensões básicas como medidas de altura e base, saber calcular suas áreas e seus perímetros etc. Nas circunstâncias que caracterizam esse contexto, identificamos com clareza a utilização de conceitos enraizados na experiência cotidiana dos alunos como modo de facilitar a construção de novos conhecimentos.

Tudo se passa como se na Matemática e, em alguns contextos, as figuras geométricas fossem encaradas implicitamente "como se fossem" entidades da nossa vida quotidiana: os rectângulos como edifícios ou caixas, os triângulos como pirâmides etc. Costuma-se designar esta forma de ver os conceitos como uma abordagem metafórica. (Matos et al., 1996, p. 53)

É fato comum que, por exemplo, na análise das propriedades de figuras geométricas, os alunos (e também os professores) transportem para o contexto adotado, por meio de metáforas, situações recolhidas de suas experiências cotidianas. Assim é que as bases dos polígonos quase sempre são identificadas com os lados colocados na horizontal e na parte mais baixa de paralelogramos ou trapézios, ou que a altura de um triângulo obtusângulo não seja facilmente identificável quando o ângulo obtuso se assenta sobre o lado colocado na horizontal. Para que os alunos construam o conhecimento de que altura e base são segmentos perpendiculares, independente da posição em que desenhamos o polígono, será preciso que vivenciem a situação proposta pelo contexto, de recobrir o plano. Ao realizarem os procedimentos de "encaixe e desencaixe" de figuras planas, os alunos tendem a transpor as barreiras das relações anteriormente construídas a respeito das propriedades dos polígonos,

\footnotetext{
12 Tradução nossa. No original: Este fenómeno universal de la relación entre sujeto y objeto, que es el darse cuenta, sólo podrá concebirse comparándolo con alguna forma particular de las relaciones entre objetos. El resultado será una metáfora.
} 
identificando-as nas figuras colocadas em variadas posições. Nesse caso, como em todos os demais, o contexto de ensino caracterizado pela ação de recobrir o plano será mais ou menos profícuo em função da qualidade das narrativas que forem compostas para sequenciarem os eventos que transportarão os significados conceituais.

Para finalizar, contextos de ensino são formados a partir de circunstâncias presentes em situações exteriores à escola e transportadas e sequenciadas de modo a compor percurso significativo para a apresentação de conteúdos previamente selecionados.

Narrativas permitem que os objetos de estudo sejam relacionados e contextualizados, conferindo-lhes descrições que os aproximam da vivência dos sujeitos, de modo a estimular nestes a atribuição de significados aos objetos.

Metáforas são recursos linguísticos que nos auxiliam a transmitir ao outro um conceito por intermédio de uma imagem certificada pelo senso comum. As metáforas, como apontado por Ortega Y Gasset, também nos auxiliam a compreender o que está mais distante de nosso conhecimento, a partir de aproximações ao desconhecido por meio de elementos que já conhecemos.

A criação de contextos de ensino que estimulem a composição de narrativas que, por sua vez, recorram a metáforas para aproximar sujeito e objeto, são, pois, elementos interrelacionáveis e fundamentais para a construção do conhecimento matemático. Foi isto o que quisemos destacar neste capítulo.

Em seguida, analisaremos características de alguns tipos de contextos de ensino que imaginamos para a apresentação de conteúdos matemáticos para o Ensino Médio. 


\title{
CAPítulo 4 - ConTeXtos Significativos: o CASO dA MATEMÁtica
}

\author{
Mas quando consigo sentir a força de um enredo matemático, \\ algo acontece na minha mente do qual nunca consigo \\ esquecer... (Ian Stewart)
}

\subsection{INTRODUÇÃO}

Neste capítulo discutiremos a composição de contextos para a apresentação de conteúdos matemáticos. Na seleção dos exemplos, nossa escolha recaiu sobre conteúdos de Ensino Médio, visto ser este o segmento de ensino sobre o qual realizamos nossa prática de tantos anos. Todavia, cremos que as condições analisadas para os contextos citados são similares àquelas que podemos conceber para apresentação de conteúdos matemáticos próprios do Ensino Fundamental.

Na composição de contextos para a apresentação de conteúdos consideramos, por um lado, aspectos da natureza cultural dos sujeitos e, por outro, as características intrínsecas da composição conceitual dos objetos de estudo. Comentemos a seguir cada aspecto.

Na seleção dos conjuntos de circunstâncias a serem relacionadas e organizadas nos roteiros, bem como na criação das narrativas capazes de conferir os significados pertinentes, levamos em consideração, primeiramente, o conhecimento dos sujeitos a respeito dos elementos constitutivos dos enredos por sobre os quais elaboramos os roteiros das atividades. Dessa forma, personagens, cenários, fenômenos, tempo histórico e outros elementos contextuais apresentam proximidade da vivência dos alunos, que, entretanto, não possuem ainda conhecimentos suficientes para estabelecerem as relações definitivas entre significados. A prototeia de relações que os alunos possuem ao adentrarem a sala de aula será a base sobre a qual as relações pré-conhecidas serão expandidas, enquanto novas relações serão construídas.

Outro aspecto considerado na composição dos contextos que exemplificaremos em seguida, diz respeito à fertilidade de relações entre significados conceituais que a nós foi permitido identificar a partir do enredo que elaborávamos. Não basta, portanto, aproximarmo- 
nos, pela via do contexto, da cultura dos sujeitos se julgarmos que serão poucas e/ou superficiais as relações de significados conceituais que estes poderão vir a construir.

Nosso estudo - e também nossa prática - apontou a possibilidade de composição de contextos para apresentação de conteúdos matemáticos nos seguintes casos, que discutiremos individualmente em seguida:

- aplicações cotidianas;

- História da Matemática;

- interdisciplinaridade;

- intradisciplinaridade.

\subsection{CONTEXTO E APLICAÇões da MATEMÁTICA EM SITUAÇõeS COTIDIANAS}

Talvez a visão mais imediata que se tenha, a respeito da contextualização dos conteúdos, esteja relacionada à possibilidade de vê-los ajudando a resolver situações de nosso cotidiano. Tal ponto de vista expressa-se comumente na inquietação dos alunos/professores, em relacionar diretamente o que estão estudando/ensinando a eventos, fenômenos, operações comerciais, produções artísticas etc., enfim, a ocorrências presentes em seu cotidiano social. Tal preocupação pode ser resumida pela procura da resposta à questão "Para que serve isto que estou aprendendo/ensinando?”. As aplicações da Matemática ao cotidiano podem constituir-se em contexto para apresentação dos conteúdos, mas tal ação não pode ser buscada com a perspectiva de tão somente responder a esta questão.

Situações cotidianas em que a presença da Matemática se evidencia como ferramenta na solução de algum problema, envolvem grande parte dos conteúdos com os quais os alunos tomam contato no Ensino Fundamental. Casos mais comuns, nesse sentido, dizem respeito, por exemplo, ao cálculo de áreas de regiões planas ou do valor de determinada operação comercial envolvendo ou não porcentagens. Em relação a conteúdos matemáticos presentes nos currículos de Ensino Médio, a ligação entre conceito e aplicação cotidiana não é tão evidente e, em alguns, casos, é mesmo inexistente. Partindo desse pressuposto, buscar responder à questão "Para que serve?" pode gerar desconforto, mesmo nos casos em que uma ou outra aplicação é detectada, visto que os conceitos caracterizam-se, normalmente, por uma universalidade que extrapola limites imediatistas. 
Se a busca por aplicações objetivas pode tornar efêmera a construção de contexto para a apresentação de conteúdos, a identificação de tais aplicações pode servir, não para responder a questão anteriormente colocada, mas sim para servir de pilar fundamental na construção de uma rede de significados que, nesse caso, estimulam a composição de um contexto, com narrativas e metáforas pertinentes. Trata-se, portanto, de utilizar o conhecimento matemático como ferramenta para, além de explicar o porquê disto ou daquilo, interpretar todo o evento, reconfigurando-o quando necessário a fim de que permita o estabelecimento da maior gama de relações conceituais.

Destacaremos, em seguida, o exemplo de um contexto elaborado para a apresentação de alguns significados associados às Matrizes. Nesse exemplo, aplicado mais de uma vez a turmas de $2^{\circ}$ ano de Ensino Médio, partimos do conhecimento prévio dos alunos a respeito da formação de imagens digitais e adaptamos procedimentos para compor o contexto que nos interessava. Durante a descrição do exemplo, identificaremos alguns dos elementos analisados anteriormente como importantes na composição de contexto para a apresentação de conteúdos.

\subsubsection{UM EXEMPLO DE CONTEXTO DE ENSINO VOLTADO PARA APLICAÇÕES COTIDIANAS: AS MATRIZES}

Números dispostos em tabelas fazem parte do cotidiano dos alunos, assim como também as operações que produzem esses valores. Tal premissa, entretanto, não nos remete a conceber apresentação das matrizes com base apenas na leitura e construção de tabelas numéricas, visto que estas habilidades estão mais próximas de serem desenvolvidas no Ensino Fundamental do que no Médio. Entendemos também que a presente conectividade lógica entre as matrizes, os determinantes e a resolução de sistemas lineares deve ser ressaltada, mas não deve concentrar a atenção única do curso, uma vez, que, nesse caso, perderíamos a oportunidade de compor contextos com vistas às aplicações das matrizes a situações cotidianas. A riqueza de aplicações das matrizes exige, portanto, vê-las abordadas sob percursos construídos por mais de um tipo de contexto.

O contexto escolhido para a apresentação de alguns significados das matrizes, que queremos destacar, consistiu na ideia da representação de imagens por intermédio de comandos binários. A unidade básica de informação, o bit, permite codificar uma única mensagem: sim ou não. Um conjunto de bits, por outro lado, pode ser utilizado para codificar 
mensagens completas, com informações de toda natureza. São essas unidades de informação os elementos constituintes de toda a lógica que permitiu aos homens desenvolverem os modernos equipamentos de comunicação.

Tomando por base a codificação de imagens através da lógica dos bits, elaboramos um percurso sobre situação parcialmente conhecida da totalidade dos alunos, envolvendo o exame de ressonância magnética. De acordo com as características da formação de contextos, que destacamos anteriormente, a prototeia de significados sobre o tema escolhido, que os alunos trouxeram para a sala de aula, serviu de base para a ampliação dos significados que ocorreu, à medida que vivenciaram as atividades concebidas para a condução do percurso.

Vimos anteriormente que narrativas estruturam-se a partir do contexto e são por eles estruturadas, de modo que se torna quase impossível conceber uma sem o outro, e vice-versa. No caso de nosso exemplo, relativo à apresentação das matrizes, a narrativa inicial, oral, envolveu a possibilidade de construirmos desenhos unindo pontos dispostos no plano, "desvendando", para tanto, o código fornecido pelos elementos de uma matriz quadrada. A atividade proposta, nesse caso, apresenta-se a seguir, mas, diferentemente da forma como foi aplicada, aparece organizada sob o formato de três problemas.

$\underline{\text { Atividade } 1 \text { - Desenhando com matrizes }}$

Problema 1 - Unindo pontos a partir de código registrado em uma matriz

Dada a matriz D e os pontos desenhados, você deve uni-los ou não, a partir do seguinte código estabelecido para os elementos da matriz D:

- $\operatorname{Se} d_{i j}=1$, unir $\boldsymbol{i} \operatorname{com} \boldsymbol{j}$

- $S e d_{i j}=0$, não unir $\boldsymbol{i} \operatorname{com} \boldsymbol{j}$

2

$$
D=\left[\begin{array}{llllll}
1 & 0 & 1 & 0 & 1 & 0 \\
0 & 1 & 0 & 1 & 0 & 1 \\
1 & 0 & 1 & 0 & 1 & 0 \\
0 & 1 & 0 & 1 & 0 & 1 \\
1 & 0 & 1 & 0 & 1 & 0 \\
0 & 1 & 0 & 1 & 0 & 1
\end{array}\right]
$$

1

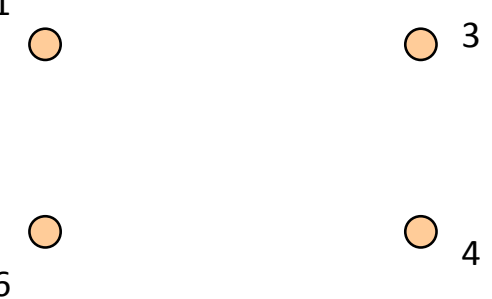


Problema 2 - Codificando um desenho por uma matriz

Os pontos numerados de 1 a 13 do desenho foram unidos a partir de código definido em uma matriz. Escreva essa matriz.
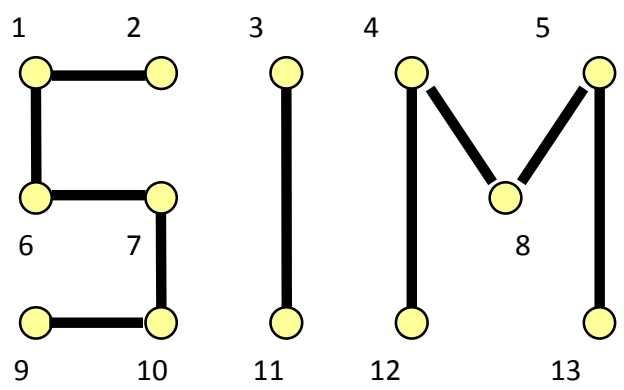

11

12

13

Problema 3 - Criando um código e um desenho.

Observe os 7 pontos representados abaixo. Você deve escrever uma matriz de codificação, com "l" ou "0", de maneira que, ao ligar os pontos na ordem determinada, seja produzida a representação de um cubo.

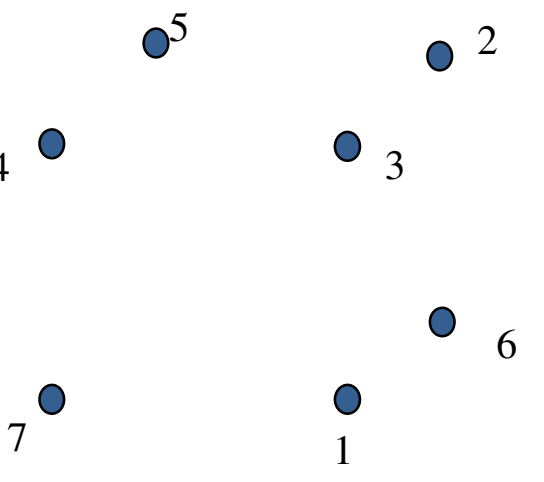

Em sequência, comentamos com os alunos a evolução da medicina a partir da implantação dos modernos exames de imagens, nos quais alguma parte do corpo do paciente é "enxergada" por dentro, permitindo ao médico detectar o tipo e o local exato em que a enfermidade se desenvolve. A sequencialidade desses comentários envolveu, na forma de narrativa oral, discussões sobre a origem dos primeiros exames de imagens a partir da descoberta dos raios X, ainda hoje utilizados. As características das imagens que as "chapas" 
de raios $\mathrm{X}$ revelam são bem diferentes daquelas reveladas por exames mais modernos, como o são, por exemplo, o exame de tomografia computadorizada ou o de ressonância magnética. Tal aspecto também fez parte da narrativa oral e das discussões que se sucederam. Uma amostra de "chapa" de raios X e uma de um filme de ressonância foram analisadas e discutidas as diferenças observáveis. Por fim, conversamos sobre o formato dos exames de ressonância, destacando que as imagens produzidas baseiam-se em espécie de fatias do corpo do paciente, fatias essas que, em conjunto, permitem a reconstituição da parte examinada. Em cada fatia, a imagem produzida pode ser imaginada como uma composição de muitas pequenas imagens, cada uma delas preenchida ou não por um tom de preto, dependendo da substância que o raio emitido pela máquina encontra pelo caminho ${ }^{13}$.

Completada a narrativa, propusemos aos alunos a realização da atividade descrita a seguir, composta de texto de apoio e conjunto de problemas, acompanhando a composição do contexto escolhido a respeito da formação de imagens a partir de codificação em bits.

\section{Atividade 2 - Princípio da tomografia}

\section{Texto de apoio da atividade}

A tomografia computadorizada é uma moderna técnica da medicina que permite visualizar o interior do corpo de uma pessoa, por meio de uma série de imagens que possibilitam aos médicos identificar diversos tipos de problemas, como, por exemplo, a existência de regiões cancerígenas. Nesta atividade aproveitaremos o modo como são tomadas as imagens de uma tomografia para simular situações-problema envolvendo matrizes.

O funcionamento de um tomógrafo computadorizado consiste, basicamente, na emissão de feixes de raios $X$ que não atravessam todo o organismo da pessoa, mas sim fazem varreduras em um único plano. Desse modo, um feixe de raios, ao varrer um plano, ou uma "fatia", projeta, ao final,

\footnotetext{
13 Adaptado de artigo intitulado Gatografia Computadorizada, da edição especial da Scientific American-Brasil, escrito por A.K. Dewdney. São Paulo: Duetto Editorial, 2007.
} 
uma imagem que é unidimensional, isto é, uma tira com trechos claros e escuros, conforme aquilo que tenha encontrado pelo caminho (órgãos, ossos etc.).

Quem já passou por esse tipo de exame sabe que, durante cerca de meia hora, um grande equipamento executa movimentos circulares e ruidosos, que está, de fato, "fatiando" nosso corpo com os feixes unidimensionais de raios $X$. $O$ feixe de raios $X$, emitidos em um único plano, projeta uma tira com trechos claros e escuros, como neste desenho:

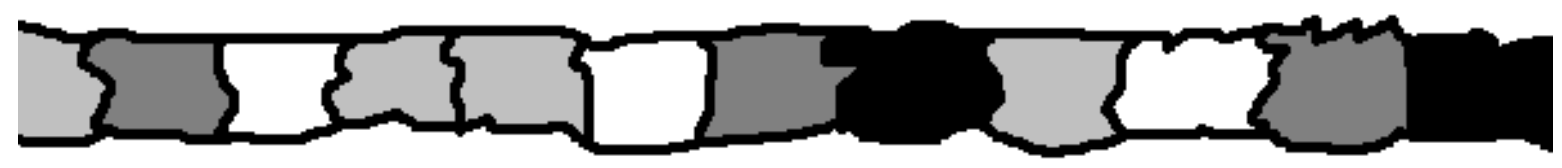

À medida que o tomógrafo se movimenta, outros feixes de raios $X$ são emitidos e novas tiras são geradas. A reunião dessas tiras, em uma única imagem, forma uma "chapa", ou um corte, semelhante ao que é mostrado no desenho seguinte:



Podemos associar os numerais 1 ou 0 aos pontos escuros ou claros, respectivamente. Além disso, simplificando a constituição dessas microrregiões claras ou escuras, vamos supor que todas tenham o formato de pequenos quadrados, de maneira que uma região plana possa ser, de fato, uma região quadriculada, em que linhas e colunas sejam numeradas de 1 a $\boldsymbol{n}$, conforme a seguinte representação, em que a malha quadriculada tem 8 linhas e 8 colunas.




Nesse caso, poderemos associar ao desenho uma matriz $8 \times 8$ formada por elementos que são, ao mesmo tempo, numerais 1 ou 0 e regiões escuras ou claras.

Quando nosso tomógrafo simplificado efetuar um corte, ou, em outras palavras, gerar uma tira de regiões claras ou escuras, serão lançados valores das quantidades de cada tipo de região, sem que todavia, sejam ainda conhecidas quais regiões têm esta ou aquela característica. Se isso for feito como no exemplo abaixo, saberemos que 4 quadrículas dessa linha deverão ser escuras. Mas quais?

4

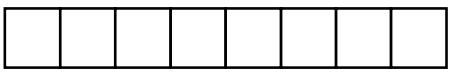

Registrando simultaneamente a quantidade de quadrículas escuras ou claras de cada coluna,é possível reconstituir a "imagem", como no caso do desenho abaixo:



Observe o exemplo seguinte, da recomposição de uma imagem em um quadriculado de $3 \times 3$.
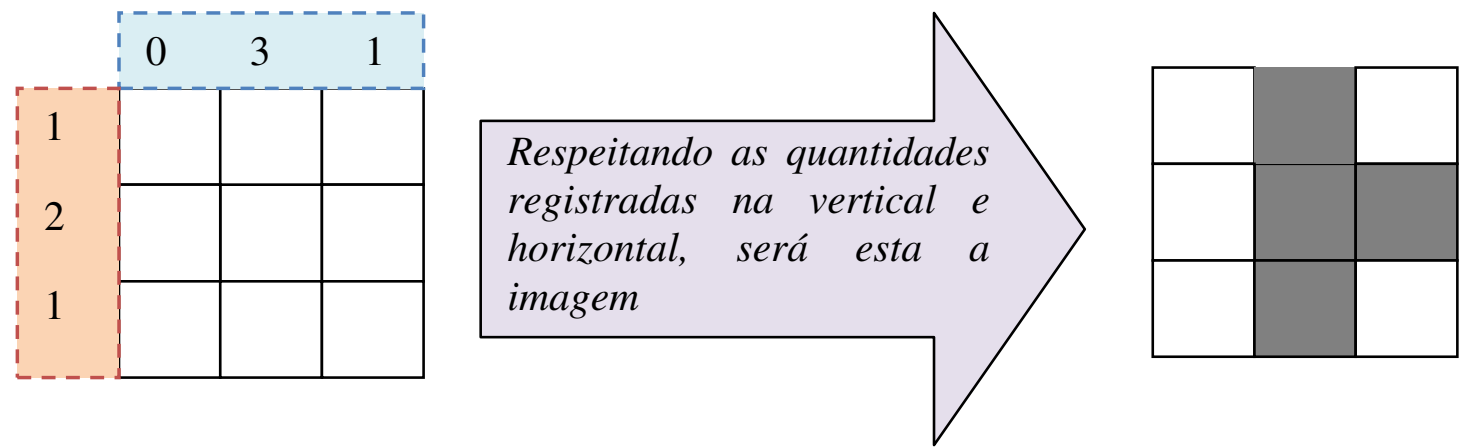

Observe nestes outros exemplos, como podemos associar a reconstituição da "imagem" a uma matriz.

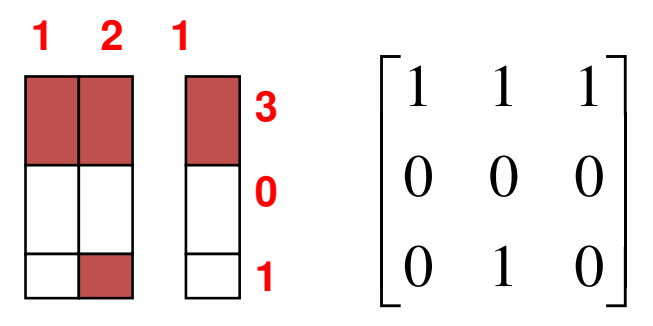

132




Problema - Determine as regiões "escuras" e escreva também uma matriz associada à composição.

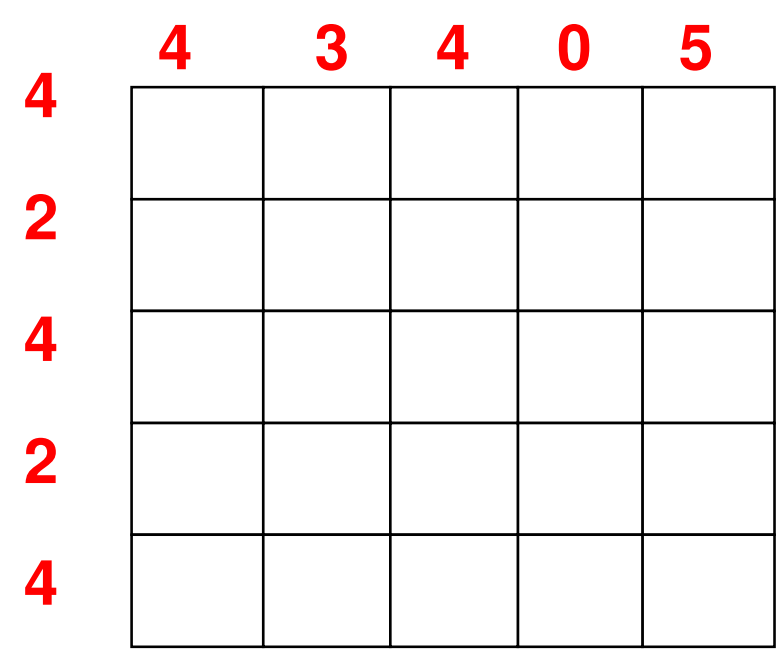

O desenvolvimento do conjunto de atividades permitiu que os alunos incorporassem novo significado àqueles com os quais identificavam as matrizes. Se outrora as matrizes eram vistas como tabelas de valores relacionando duas grandezas, entre as quais podiam realizar operações, foi-lhes possível identificar as matrizes como elementos capazes de conter informações associadas à construção de imagens no plano.

Complementando o percurso concebido sobre o contexto da representação de imagens por intermédio de bits de informação, foi proposto aos alunos refletirem sobre o caso que, dentre os três analisados, mais os aproximou de suas experiências cotidianas.

"Resolução de imagens: os pixels" é o título da terceira atividade ${ }^{14}$. Os pixels são elementos unitários de formação de imagens digitais e estão presentes em quase todos os equipamentos eletrônicos atuais, como telas de computadores, máquinas fotográficas, televisores etc. Nesta atividade, os alunos foram convidados a refletir sobre o fato de que uma imagem digital é decomposta em número determinado de pixels, dispostos em formato de uma matriz, com elevado número de linhas e de colunas. Um determinado comando emitido a cada pixel transmite a ele uma cor, ou faixa de cor, de maneira que a imagem seja formada pelo conjunto de todos os pixels, com todas as cores e tons harmonizados.

\footnotetext{
${ }^{14}$ As três atividades que compõem o percurso por sobre o contexto da reprodução de imagens a partir de comandos de bits de informação foram elaboradas, originalmente, para os Cadernos de Atividades da Secretaria da Educação do Estado de São Paulo, em 2008.
} 
Atividade 3 - Resolução de imagens: os pixels

\section{Texto de apoio da atividade}

O registro de uma foto no papel ou em uma tela de computador é obtido a partir da reunião de várias unidades de imagem justapostas. Cada uma dessas unidades tem apenas uma cor e é denominada pixel (picture element). O conjunto dos pixels dá a quem vê a impressão de

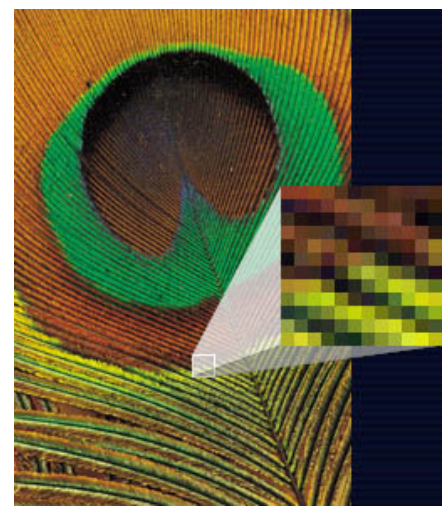
algo contínuo, muito embora a ampliação da foto mostre claramente a descontinuidade da gradação de cores, como se pode observar na figura ao lado.

Não há dimensão fixa para um pixel, mas é possível inferir que, em uma mesma área, quanto menor for um pixel, maior poderá ser a quantidade deles, implicando em uma foto de melhor qualidade ou, de maior resolução.

Ao adquirir uma máquina fotográfica digital uma das primeiras características avaliadas pelo comprador são os megapixels. Uma máquina de 6 megapixels (6 MP) divide uma determinada área em 6 milhões de pixels $\left(6 \times 10^{6}\right)$, enquanto outra, de 7.1 MP é capaz de dividir a mesma área em 7 milhões e 100 mil pixels $\left(7,1 \times 10^{6}\right)$. Assim, apenas por esse quesito, é possível avaliar que a qualidade da segunda câmera é superior à da primeira.

Uma fotografia, dessa maneira, pode ser entendida como uma matriz formada por $\boldsymbol{n}$ elementos em cada um deles é um pixel de imagem. Quanto mais elementos a matriz contiver em uma mesma área, melhor será a resolução da fotografia. Observe, por exemplo, os desenhos dos retângulos seguintes, nos quais foi inserida a letra $R$. Acima de cada retângulo aparece registrado a quantidade de pixels. Nessa ilustração fica claro como a qualidade da imagem aumenta com o aumento da quantidade de pixels.
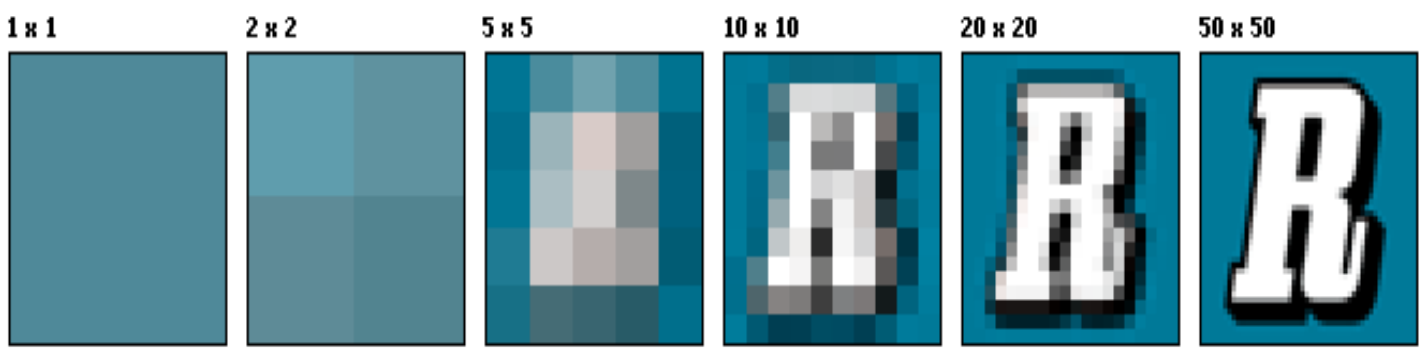

$100 \times 100$

O tamanho de uma imagem digital é definido pela ordem da matriz,

isto é, pela quantidade de linhas e colunas que a forma. A flor ao lado, por exemplo, tem 119 linhas e 116 colunas de tamanho, em um total de $119 \times 116=13804$ pixels.

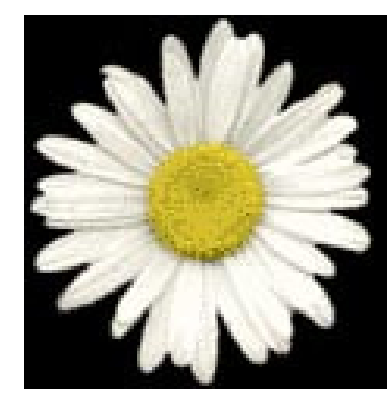


Problemas - Um determinado modelo de máquina digital pode alterar a resolução da foto. À escolha do fotógrafo, as fotos podem ser produzidas com as seguintes especificações:

- 7.1 MP: $3072 \times 2304$ pixels

- 6.1 MP: $3072 \times 2048$ pixels

- 4.0 MP: $2304 \times 1728$ pixels

- 1.9 MP: $1600 \times 1200$ pixels

- 0.8 MP: $1024 \times 768$ pixels

1) Considere uma foto de $7.1 \mathrm{MP}$ de resolução em que a linha 1000 da matriz seja formada apenas por pixels de cor verde, divididos igualmente entre 3 tonalidades em ordem crescente de posição nas colunas:

Tonalidade 1 : Tonalidade 2:

Tonalidade 3:

Assim, dos n elementos da $1000^{a}$ linha da matriz, os $\frac{n}{3}$ primeiros são verdes na tonalidade 1 , os $\frac{n}{3}$ seguintes são verdes na tonalidade 2 e os $\frac{n}{3}$ últimos são verdes na tonalidade 3. Nessa condição, qual será a tonalidade, 1, 2 ou 3 do seguinte pixel $a_{i, j}$, isto é, do elemento da matriz que ocupa a linha i e a coluna $j$ ?
A) $a_{1000,1000}$
B) $\mathrm{a}_{1000,500}$
C) $a_{1000,2000}$

2) Considere uma foto de $1.9 \mathrm{MP}$ de resolução em que todos os elementos $\boldsymbol{b}_{i j}$ da matriz sejam pixels de cor azul, de modo que cada elemento $\boldsymbol{b}_{i j}$, isto é, o elemento que ocupa na matriz a posição dada pela linha $\boldsymbol{i}$ e pela coluna $\boldsymbol{j}$, seja dado pela sentença $\boldsymbol{b}_{i j}=2 \boldsymbol{i}-\boldsymbol{j}$ e as tonalidades são associadas ao pixel de acordo com o seguinte código:

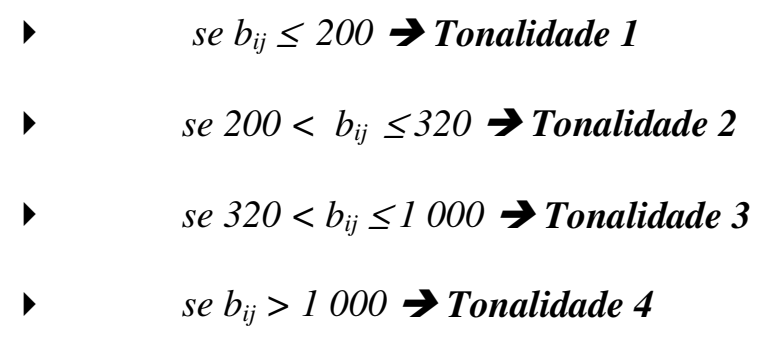

Nessas condições, qual é a tonalidade, 1, 2, 3 ou 4, do elemento:
a) $\mathrm{b}_{40,100}$ ?
b) $\mathrm{b}_{1000,1000}$ ?
c) que estiver na $1200^{a}$ linha e $1200^{a}$ coluna?
d) No exercício anterior, quantos pixels da $300^{a}$ linha terão tonalidade 3 ? 
Queremos ressaltar, validando afirmação anterior, que a composição do contexto para a apresentação de outros significados para as matrizes não considerou, em nenhum instante, proposta de responder imediatamente à questão do "Para que serve?" o que se está estudando. Matrizes servem, ou melhor dito, significam, muito além daquilo apresentado nas atividades exemplificadas. O trabalho com o conteúdo, portanto, não pode esgotar-se com a realização desse ou de qualquer outro conjunto de atividades, se tivermos por princípio que o conhecimento de qualquer objeto nunca é completo, apenas se amplia à medida que novas relações são construídas, tendo em vista a formação de uma rede de significados. De qualquer maneira, o contexto adotado e as narrativas que o compuseram permitiram dar substância às atividades realizadas.

$\mathrm{Na}$ formulação da sequência de atividades elaboradas para a apresentação de significados para as matrizes, consideramos, mesmo que intuitivamente, alguns dos aspectos identificados por Goodman (1995) em sua "feitura de mundos". Nesse sentido, podemos citar, por exemplo, que o aspecto da Ordenação regulou nossa conduta de partir da união de pontos representados no plano para, em seguida, buscar o significado da construção de imagens e sua associação a matrizes de codificação, diferentemente da conduta habitual de iniciar-se o estudo das matrizes pela construção de tabelas numéricas a partir de condições expressas por equações matemáticas.

Em relação à Supressão e completação, este aspecto esteve presente na escolha dos significados conceituais que pretendíamos destacar no estudo das matrizes. Em respeito a isto e, por conseguinte, ao contexto composto, optamos por relegar a discussão sobre as operações entre matrizes e suas propriedades a um plano posterior. Assim, se inicialmente o estudo das operações foi suprimido para permitir maior uniformidade à sequência de atividades componentes do contexto, as operações não deixaram, todavia de serem analisadas no sentido de completar e de atribuir ainda mais significado aos conceitos analisados.

Os elementos do cotidiano que adotamos para a exemplificação das atividades, especialmente aquelas envolvendo o princípio da tomografia e os pixels, precisaram ser reconfiguradas para serem apresentadas aos alunos. Nessa reconfiguração, optamos por simplificações e adaptações que permitiram, a nosso ver, manter características essenciais do conceito original, no sentido de que ele pudesse ser reconhecido nas atividades. O quinto aspecto relacionado por Goodman, referente à Deformação, esteve, assim, contemplado. 
Teremos oportunidade de apontar estes e outros aspectos da composição contextual também nos próximos casos que analisaremos.

 COTIDIANAS: A TRIGONOMETRIA}

Alguns conteúdos matemáticos, dada sua universalidade, permitem ser abordados sob a referência de vários contextos; a trigonometria é um deles.

Os conceitos de trigonometria podem ser enxergados em diversas aplicações cotidianas, como por exemplo, no caso que apresentaremos em seguida. Também não são poucas as relações que a trigonometria guarda com conteúdos de outras áreas do conhecimento, especialmente com a Física, no estudo dos movimentos periódicos, como também analisaremos mais adiante. As funções trigonométricas mostram-se em múltiplas relações internas à própria Matemática, como é o caso, por exemplo, das relações com os números complexos, e a história da Matemática registra diversas passagens em que foi necessária a aplicação de uma razão trigonométrica à resolução de determinada situaçãoproblema. São, portanto, diferentes possibilidades para a contextualização do ensino da trigonometria. Consideremos, imediatamente, uma delas.

Para compreender um pouco da geração, propagação e recepção de ondas eletromagnéticas, é preciso conhecer as funções trigonométricas. De fato, todo o estudo das ondas é modelado por funções envolvendo soma e/ou subtrações de senos e/ou cossenos, por intermédio de uma série de Fourier. Para mostrar um pouco das características dessa modelagem a nossos alunos, podemos recorrer a contexto exclusivamente interdisciplinar, mas podemos também destacar prioritariamente a aplicação dos conceitos em situações cotidianas.

O conjunto de atividades que apresentamos a seguir contextualiza-se sobre a transmissão de sinal eletromagnético, algo bastante frequente nas operações cotidianas de nossos alunos, como nos casos do uso de um controle remoto e do telefone celular.

O motivo principal do contexto desse conjunto de atividades é significativamente pródigo à produção de narrativas. Para imaginar apenas uma delas, podemos questionar nossos alunos sobre como avaliam que um aparelho de telefonia celular consegue identificar que está sendo chamado por outro, situado em outra cidade, às vezes muito distante, a partir, 
apenas, da digitação de uma combinação determinada de oito dígitos. Decerto isto lhes parecerá estranho, e poderá servir de mote para o encadeamento de perguntas e respostas capazes de gerar diversas narrativas interessantes.

Salientamos que os problemas que listamos a seguir não completam o contexto adotado para a apresentação das funções trigonométricas, sendo apenas uma amostra dos elementos contextuais que compõem a atividade.

Problema 1 - Leia as descrições seguintes, sobre ações que você realiza cotidianamente e que estão relacionadas às funções trigonométricas seno elou cosseno. Após a leitura, discuta com seus colegas as respostas que irão elaborar a partir de seus conhecimentos anteriores sobre os temas.

a) Quando você aperta o botão do aparelho de controle remoto, consegue interferir na programação de sua TV, por exemplo. Nesse ato, o aparelho emite um sinal na forma de onda eletromagnética até a TV que, por sua vez, respeita sua vontade e efetua a operação solicitada. O que ocorre nesse percurso?

b) Com o controle remoto de sua TV você não consegue fazer funcionar seu aparelho de som, pois este aceita apenas a onda emitida por outro aparelho de controle remoto. Por que o controle da TV não faz funcionar o aparelho de som?

c) Ao ligar o rádio do automóvel você consegue ouvir as músicas tocadas em sua estação preferida. Mudando de estação, consegue ouvir, por exemplo, o noticiário do dia. Como é que o rádio consegue sintonizar uma estação de cada vez?

Problema 2 - O gráfico de uma função do tipo $y=$ AsenBx assemelha-se a uma onda, como vimos durante uma de nossas aulas. Dependendo dos valores das constantes A e B, a onda poderá ser mais "esticada" ou mais "comprimida", tanto na vertical quanto na horizontal. Essas variações estão relacionadas a dois conceitos importantes da geração e propagação das ondas de modo geral: amplitude e frequência. Veja o esquema seguinte com destaque para esses dois conceitos:

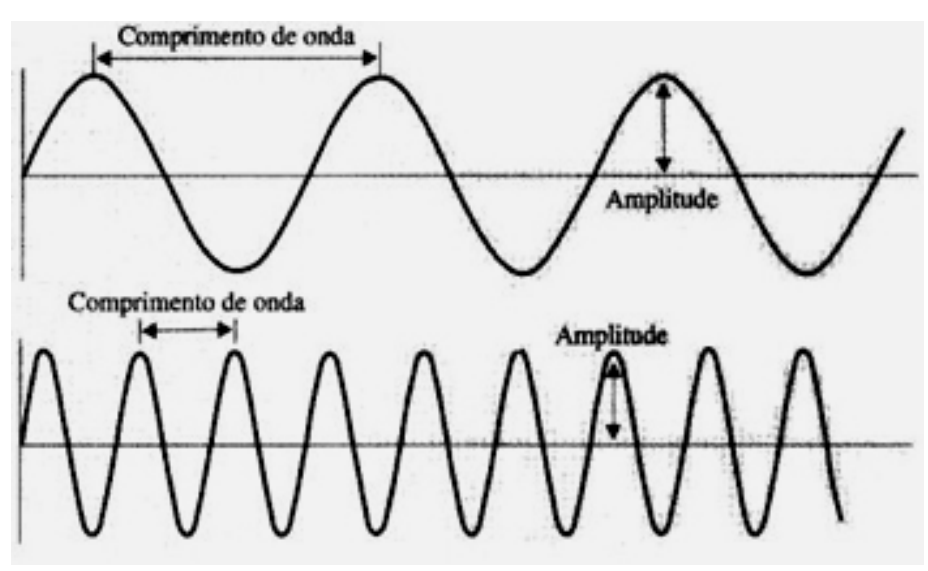

Comprimento de onda: distância entre duas cristas.

Frequência: quantidade de comprimentos de onda que passam por um ponto em uma unidade de tempo. No caso de ondas eletromagnéticas, a unidade usual é o hertz $(\mathrm{Hz})$, referente à quantidade de comprimentos de onda por segundo. 
Com a ajuda do software gráfico (Graphmática, Geogebra ou Winplot), desenhe os gráficos das funções definidas pelas equações dadas abaixo. Em cada caso, escreva o valor do comprimento de onda, da amplitude e da frequência, nas unidades dadas.

a) $y=2 . \operatorname{sen}(\pi t) \quad(y$ em cm e $t$ em segundos $)$

b) $y=10 \cdot \operatorname{sen}\left(\frac{\pi}{10} t\right) \quad(y$ em cm et em segundos $)$

c) $y=250 \cdot \operatorname{sen}\left(\frac{2 \pi}{125} t\right) \quad$ (y em m e $t$ em minutos $)$

Problema 3 - Uma estação AM de rádio opera na faixa de $90 \mathrm{kHz}$, ou seja, 90 quilo-hertz, ou ainda, 90.000 hertz. Supondo que a amplitude da onda que você esteja recebendo dessa rádio seja da ordem de $0,5 \mathrm{~m}$, represente a onda em um gráfico cartesiano com a unidade segundos $(\mathrm{s}$ ) no eixo horizontal.

O estudo das ondas eletromagnéticas envolve muito mais do que aquilo que é destacado na atividade. Do contrário, bastaria apenas pensar que a reflexão sobre o comportamento da luz conduziu às experiências de pensamento de Albert Einstein e a elaboração da teoria da relatividade. A identificação dos aspectos a serem abordados na atividade, compondo-a de modo a manter significatividade, passa pela mobilização, por parte do professor, de algumas das competências apontadas por Machado (2009). Consideremos duas dessas competências: mapear e tecer.

Como afirmamos, o estudo das ondas envolve a aplicação de diversos conceitos, matemáticos e físicos. Um conjunto de atividades para o ensino de parte desses conceitos, levando em conta o estágio educacional em que os alunos se situam, exigirá do professor a importante tarefa de mapear as relevâncias que considera para composição do contexto da atividade. Quanto mais ampla for a rede de significações sobre a qual se enxerga o conceito, maior será a importância do mapeamento realizado pelo professor, no sentido de destacar os significados e as relações que pretende sejam construídas por seus alunos.

A partir da identificação dos significados, em função das intenções projetadas para a atividade, caberá ao professor elaborar um percurso sobre os significados, ordenando-os segundo um critério que considere apropriado. Nessa ação, o professor tece o caminho que estimulará seus alunos a percorrer no sentido da construção conceitual.

No caso do exemplo da apresentação das funções trigonométricas, com base em contexto voltado para aplicações cotidianas, nosso mapeamento identificou a relevância dos 
significados de frequência de uma onda e da representação dessa onda por intermédio de um gráfico cartesiano. Elaboramos, então, um percurso que partiu da constatação da presença dos sinais eletromagnéticos à nossa volta, seguiu para a identificação dos conceitos importantes para a compreensão da fenomenologia associada, finalizando com a associação entre tais conceitos e a representação cartesiana de uma função matemática.

\subsection{CONTEXTOS INTERDISCIPLINARES PARA O ENSINO DE MATEMÁtICA}

Boa parte dos cursos da educação básica estrutura-se a partir de organizações curriculares que priorizam a multidisciplinaridade. Nesses casos, a apresentação dos conteúdos segue a lógica física expressa na grade de aulas, ou seja, algumas aulas semanais de Matemática, tantas de História, outras de Português etc., não ocorrendo momentos em que blocos de conteúdos sejam abordados conjuntamente por duas ou mais disciplinas, exceto o mínimo de interação institucional previsto para momentos específicos, como, por exemplo, Estudos do Meio ou Feira de Ciências. Nesse contexto, a interdisciplinaridade coloca-se praticamente ao largo do processo educativo.

A fragmentação dos conteúdos, expressa em organizações multidisciplinares, é tributária de uma concepção epistemológica segundo a qual o conhecimento é construído a partir da justaposição de pequenos lotes de significados conceituais, de limites muito bem demarcados, compondo uma grande área sobre a qual se distribuem todos os conhecimentos adquiridos. Nessa área, em um lote encontramos conhecimentos da Química; em outro, nos deparamos com a Física e os fenômenos que esta explica; no lote ao lado situam-se os objetos de estudo da História, e assim por diante.

Se a concepção de um conhecimento que mantém rígidas fronteiras disciplinares anteriormente não era apropriada para explicar a construção do conhecimento humano, menos ainda pode contemplar, em nossos dias, as diversas manifestações e fenômenos que ocorrem além dos muros escolares e que envolvem múltiplas relações entre significados não claramente identificados com esta ou aquela disciplina curricular. A qual disciplina pertence, por exemplo, os limites do estudo da estrutura da matéria? À Física ou à Química? O que é a Termodinâmica senão corpo de conhecimentos que envolve conceitos de várias disciplinas curriculares? Como entender a gama de acontecimentos na esfera mundial, como guerras, ocupações, políticas energéticas, restrições à imigração, nacionalismos exacerbados e crises econômicas, sem relacionar eventos à luz de elementos das Ciências, da Matemática e das 
Humanidades? A interdisciplinaridade é, nesse contexto, a conferência na qual se aglutinam os agentes que buscam uma visão sintética e unificadora do conhecimento, vencendo, dessa maneira, a fragmentação disciplinar.

$\mathrm{Na}$ busca pela interdisciplinaridade, observamos casos de aglutinação de esforços de várias disciplinas em função de agregar significados a conteúdos de apenas uma delas. Um exemplo dessa situação pode ser observado nos projetos de visitas a museus de arte ou de ciências, ou ainda em viagens de estudo do meio. Nesses casos, muitas vezes identifica-se em uma disciplina um tema próprio de sua área de conhecimento, e buscam-se as ligações que esse tema permite estabelecer com conceitos das demais. Numa visita ao litoral, por exemplo, o contato dos alunos com elementos da vida das espécies marinhas será facilitado, e poderá ser esta a atividade principal e motivadora do projeto. Todavia, não é difícil que, em situações dessa natureza, o professor de Matemática seja convidado a participar com um "projeto" de medida da altura de alguns coqueiros da orla, ou do cálculo da área de uma parte demarcada da areia, ações, enfim que não precisariam ser realizadas no ambiente praieiro. Assim, espera-se que a atividade de Biologia sirva como elemento aglutinador para atividades de outras disciplinas. A interdisciplinaridade, portanto, pode não estar presente em situações como essa.

Roland Barthes, em sua obra O rumor da língua, de 1988, destacou essencial aspecto da interdisciplinaridade ao escrever: A interdisciplinaridade consiste em criar um objeto novo que não pertença a ninguém. (p. 99)

Se a busca por relações interdisciplinares, construídas a partir de um conceito disciplinar, pode ser estimulada, precisa ficar claro que a interdisciplinaridade apontada em documentos oficiais e por autores como Barthes, exige pensar adiante; exige pensar na possibilidade de tecer uma rede de significados conceituais com base em temas identificados em planos acima dos tradicionais âmbitos disciplinares e que, dada a sua universalidade, forneçam a energia para a ligação entre conceitos de diversas disciplinas. Um desses temas, que não pertence a ninguém, ou seja, não permite ser apropriado por uma única disciplina curricular, foi por nós utilizado como elemento estruturador de contexto de ensino. Trata-se do fenômeno das marés, que passamos a descrever a seguir. 


\subsubsection{UM EXEMPLO DE CONTEXTO DE ENSINO VOLTADO PARA A INTERDISCIPLINARIDADE: O FENÔMENO DAS MARÉS.}

A composição de contexto de ensino, em nossa opinião, precisa considerar especialmente duas condições. A primeira condição diz respeito à possibilidade de que as diferentes relações entre significados conceituais possam ser compreendidas logicamente pelos sujeitos envolvidos. Para tanto, é importante que os objetos de estudo, componentes do contexto de ensino, se aproximem, de alguma forma, da cultura dos sujeitos. Essa condição, supomos, foi contemplada na escolha do tema Fenômeno das marés, na medida em que a confrontação do ser humano com o mar vem de muito longe, seja por intermédio de relatos históricos, por lendas que embalam a imaginação infantil, pela grandiosidade do ambiente marinho quando comparado à superfície terrestre, pela fúria das ondas que destroem comunidades etc.

A segunda condição que consideramos importante observar na composição do contexto consiste na fertilidade das relações de significados que podemos estimular com base nele. Quanto mais rico for o contexto em sua capacidade de relacionar significados de diferentes áreas do conhecimento, mais profícua poderá ser a construção conceitual, respeitada a condição anterior, referente à proximidade entre a cultura dos sujeitos e os elementos contextuais. Nesse sentido, o Fenômeno das marés, sendo tema que não se caracteriza por pertencer a alguma disciplina por excelência, permite aglutinar amplo espectro de significados identificados com várias disciplinas em particular. Comentemos sobre alguns desses significados.

Em relação à Matemática, o estudo das marés está relacionado à possibilidade de modelar fenômenos por intermédio de funções periódicas envolvendo senos e/ou cossenos. A trigonometria encontra na análise do sobe e desce das marés contexto fértil para o desenvolvimento dos conceitos relativos ao modelo da circunferência trigonométrica e das funções trigonométricas de modo geral.

A periodicidade das marés é explicada principalmente pelas leis da mecânica clássica, especialmente as que se referem à Gravitação Universal, formulada por Isaac Newton no século XVII. Dessa forma, é possível observar de forma clara a pertinência da Física em desenvolver o contexto das marés em conjunto com a Matemática.

A ocupação do espaço próximo aos limites marinhos exige das comunidades o conhecimento das características das marés. De fato, em muitos casos, a vida dessas 
comunidades é totalmente regulada pelos horários das marés, na medida em que o entrar e sair do espaço ocupado está atrelado à altura em que a maré se apresenta. Em consequência, as marés são também elementos reguladores das atividades econômicas dessas comunidades. Nota-se, assim, a riqueza que o tema das marés pode apresentar no estudo de elementos de Geografia econômica.

Além da Matemática, da Física e da Geografia, anteriormente citadas, o tema das marés permite o estudo de elementos de outras disciplinas curriculares, como, por exemplo, a Biologia e a Química. Dessa forma, o contexto interdisciplinar composto a partir do fenômeno das marés, apesar de não pertencer a nenhuma disciplina, permite aglutinar várias delas em torno da construção de uma importante rede de significados conceituais.

Passamos, em seguida, a descrever, de forma simplificada, as etapas da aplicação do contexto elaborado sobre o fenômeno das marés para alunos de $2^{\circ}$ ano de Ensino Médio.

\section{$\underline{\text { Atividade } 1 \text { - Representando a periodicidade }}$}

A evolução do comprimento da sombra de uma estaca com o passar das estações do ano permite observar a periodicidade do movimento da Terra ao redor do Sol. O esquema abaixo reproduz a ideia principal.

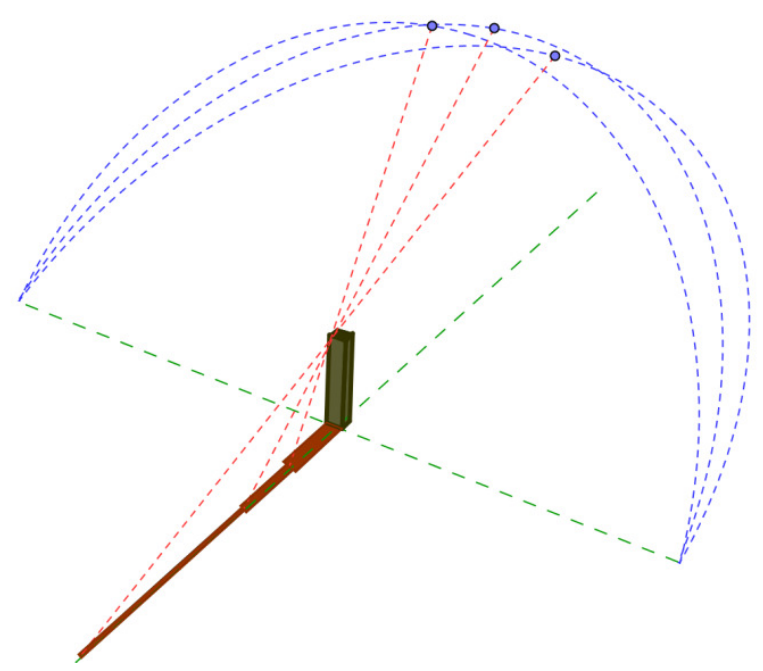

A inclinação do Sol em relação ao zênite varia de acordo com a passagem dos dias do ano. No verão, o Sol passa mais a pino, quase sobre nossas cabeças. Nessa condição, o comprimento da sombra de uma estaca é menor do que quando observada no mesmo horário em outra época do ano. 
No inverno, o comprimento da sombra é máximo, enquanto na primavera e no outono esse comprimento é médio entre as medidas de inverno e de verão. As datas emblemáticas para as medidas da sombra são, portanto, aquelas que marcam a entradas das estações, ou sejam, os solstícios de verão e de inverno e os equinócios de primavera e de outono.

Represente em um sistema de eixos a evolução do comprimento da sombra da estaca durante período de dois anos. Para tanto, registre no eixo horizontal os meses do ano e no eixo vertical, os comprimentos da sombra.

Essa atividade é o primeiro contato dos alunos com a questão da periodicidade dos movimentos. Assim, a representação que fazem da experiência de pensamento que realizam pode prescindir ainda de maior fidelidade, como podemos observar nos registros seguintes.
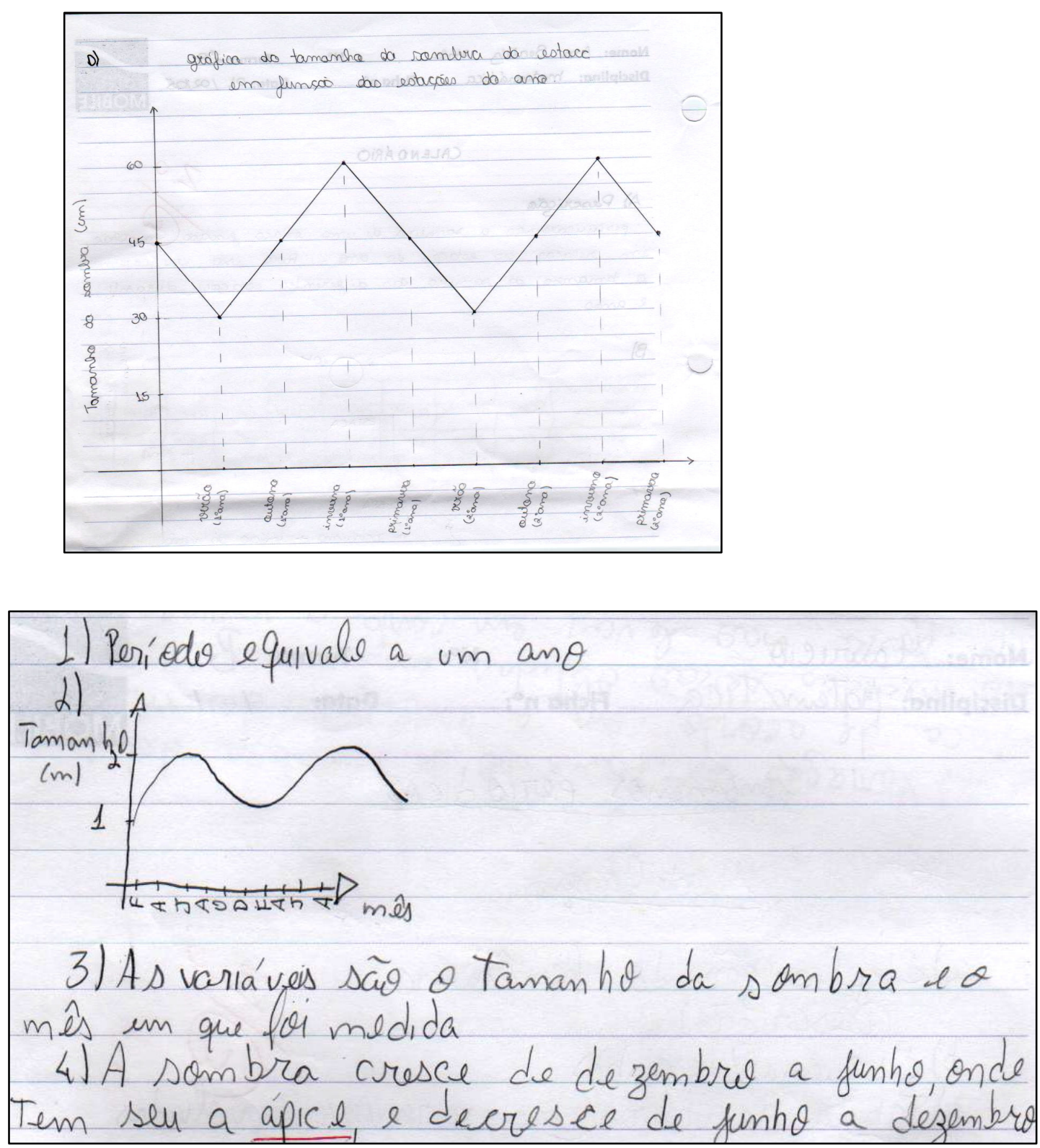
Em seguida, o modelo da circunferência trigonométrica é construído como um recurso para a representação correta de fenômenos periódicos semelhantes ao da evolução do comprimento da sombra. Paralelamente à discussão de outros exemplos de fenômenos periódicos, os alunos são apresentados às funções trigonométricas seno e cosseno, quando então têm oportunidade de analisar as características e os gráficos dessas funções. Isso feito, sugere-se o estudo das marés como elemento principal do contexto estabelecido.

No próximo estágio, os alunos são convidados a acessarem site da internet que disponibiliza a altura das marés diárias em portos do Brasil. Escolhem um porto, registram a altura das marés altas, transportam os valores para uma planilha que os auxilia na construção do gráfico.

\section{$\underline{\text { Atividade } 2 \text { - O gráfico das marés }}$}

No endereço https://www.mar.mil.br/dhn/chm/tabuas/index.htm, poderão ser obtidos dados sobre as alturas das marés de vários portos do Brasil, a partir da escolha de uma data determinada. Para realizar a atividade você deve:

- Selecionar um porto e listar os valores das alturas das marés altas de dois meses seguidos. Você deve obter cerca de 120 registros.

- Transferir os dados obtidos para uma planilha Excel.

- Desenhar, com a ajuda da planilha, o gráfico de linhas representativo da evolução das alturas das marés altas do porto que selecionou.

- Realizar as aproximações que julgar necessárias para que o gráfico desenhado possa ser modelado por uma equação do tipo $y=A+B \operatorname{sen}(C x)$ ou $y=A+B \cos (C x)$. 
Os registros seguintes mostram dois exemplos de resultados obtidos:
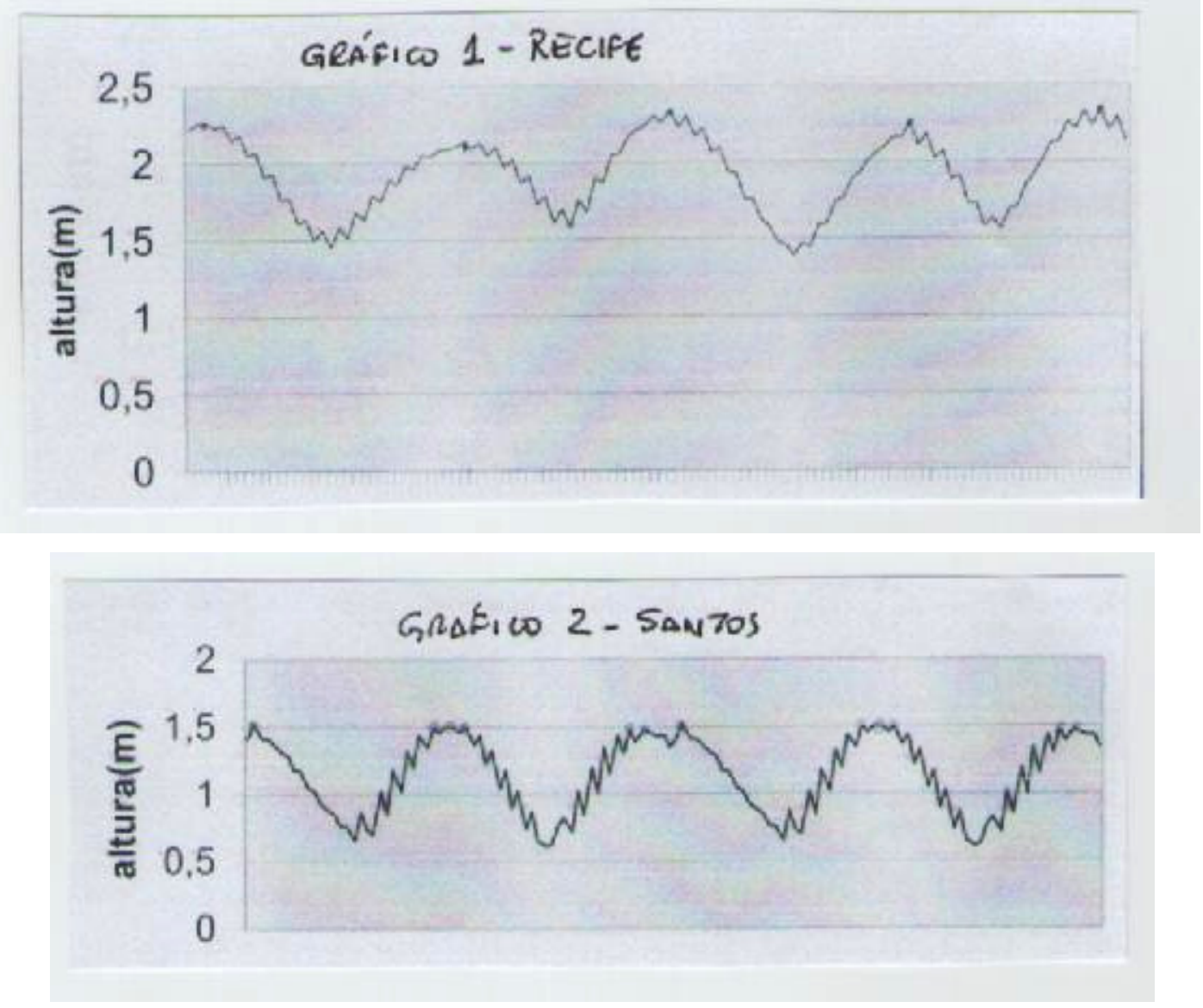

Esses gráficos, como se pode notar, assemelham-se a gráficos de funções seno ou cosseno, e o trabalho dos alunos consistiu na determinação de equações que pudessem representar aproximadamente cada uma das curvas desenhadas, configurando, dessa maneira, uma autêntica atividade de modelagem matemática.

Os gráficos desenhados, como afirmamos, representam as alturas das marés altas durante períodos de tempo correspondentes a dois meses, aproximadamente. Observando-os, podemos perceber que há quatro momentos em que as marés altas de cada localidade são máximas, o que se explica pela posição relativa entre Sol, Lua e Terra, ou mais diretamente, pelas fases da Lua. De fato, a atração gravitacional da Lua, presente em maior intensidade nas fases de lua nova e de lua cheia, é a principal responsável pelas alterações na altura das marés, aspecto esse que pode ser explorado pela Física, na gravitação, incluindo-se aspectos relativos ao movimento circular (força centrípeta, velocidade angular, força de Coriolis etc.)

Vale destacar a riqueza do tema Fenômeno das marés, escolhido como elemento estruturador do contexto de ensino, no que se refere a sua capacidade de aglutinação de narrativas de todo o tipo. Nesse sentido, destacamos, por exemplo, narrativas que envolvem a 
maneira pela qual as fases da Lua, e a consequente altura das marés, regulam a vida de comunidades de pescadores, a partir da saída e chegada das embarcações.

As recentes e constantes incidências de tsunamis nas costas de alguns países, bem como os estragos que produzem, formam também importante combustível para, por um lado, estimular a produção de narrativas e, por outro, ampliar o espectro do estudo da geração e propagação das ondas. Dessa forma, consideramos que as inter-relações que acompanham os fatos e as ideias associadas ao Fenômeno das marés permitem que sejam elaboradas situações de ensino capazes de configurar contexto apropriado ao desenvolvimento de conteúdos interdisciplinares.

\subsection{O CONTEXTO E A HiSTória dA MATEMÁtiCA NO ENSINO dA MATEMÁTiCA}

A História da Matemática apresenta conjuntos de circunstâncias que podem ser escolhidos para composição de contextos de ensino. Não se trata, entretanto, de tão somente destacar as características dos conceitos e localizar historicamente as iniciativas de estudiosos na produção do conhecimento sobre tais conceitos, como por vezes observamos em boxes de livros didáticos contendo dados biográficos sobre este ou aquele matemático famoso que viveu em séculos anteriores. Estudar Matemática com base em contexto composto a partir da História da Matemática representa resignificar elementos da época do surgimento do conceito, especialmente os culturais, com o objetivo de produzir sequências de atividades que aproximem as condições históricas da realidade atual do estudante. Para tanto, a presença de alguns elementos é decisiva, como apontaremos em seguida.

Um primeiro aspecto que merece destaque diz respeito à concepção do professor em relação à maneira com que enxerga a Matemática. Sobre isso, Motta (2006) destaca:

Para aqueles que veem a Matemática como uma ciência pronta e acabada e o ensino como uma relação de dominação, a História da Matemática encontra pouco espaço no processo de ensino-aprendizagem. Em contrapartida, estudar a História da Matemática como uma das múltiplas manifestações culturais da humanidade torna o conhecimento matemático significativo e facilita o entendimento das relações entre este conhecimento e o homem em um dado contexto cultural. (p. 108) 
Estamos, portanto, diante de uma decisão do professor claramente baseada na confiança que tem ou não de que, como afirmou Radford ${ }^{15} o$ conhecimento está profundamente enraizado e configurado pelo seu contexto social e cultural. (tradução nossa) $(1997, \xi 4)$

A afirmação de Radford destaca a importância de propor a introdução no ensino de aspectos da História da Matemática com base na análise das relações socioculturais históricas dos conceitos, bem como no estabelecimento de relações entre condições passadas e atuais, de maneira que a construção conceitual esteja agregada à formação de valores. Desse modo, conceitos matemáticos apresentados com base no contexto histórico destinam-se não apenas a um conhecimento imediato do estudante sobre aplicações ou formalizações pertinentes, mas também à sua formação pessoal.

Em confronto com a possibilidade de utilizar a História da Matemática como recurso pedagógico que considere as relações culturais, destacamos a noção de obstáculos epistemológicos, proposta por Bachelard, segundo a qual, em síntese,

[...] o conhecimento científico ocorre por meio da superação de obstáculos surgidos no ato de conhecer na forma de conflitos e lentidões que causam a estagnação e até a regressão no progresso da ciência: são conhecimentos antigos, que resistem às novas concepções para manter a estabilidade intelectual. (Motta, 2006, p. 57)

A hipótese lançada por Bachelard, que acentua a necessidade de ocorrência de rupturas no processo de construção da Ciência, poderia referendar a aplicação da História da Matemática em etapas de construção de conhecimento matemático na medida em que permitiria identificar obstáculos epistemológicos superados na história associada ao conceito, transformando-os em situações-problema que auxiliassem a construção conceitual. Em outras palavras, tais obstáculos seriam uma fonte para a busca de problemas, como destacou Brousseau (1983):

A pesquisa dos indícios históricos correspondentes não é mais, nesse caso, aquela das dificuldades ou dos erros semelhantes do nosso ponto de vista de

\footnotetext{
${ }^{15}$ Este artigo foi publicado em For the Learning of Mathematics, (February 1997), com o título "On Psychology, Historical Epistemology and the Teaching of Mathematics: Towards a Socio-Cultural History of Mathematics"
} 
hoje, mas aquela dos fracassos característicos de um certo saber, em sua imersão dentro dos conhecimentos atuais... Os pontos de ruptura não são mais os das datas de descobertas mas das problemáticas e dos tipos de saber utilizados [...] (p. 191 e 192)

A opção pedagógica por um tratamento conceitual a partir da História da Matemática parece privilegiar aspectos próprios da problemática do desenvolvimento científico e intelectual, da pesquisa acadêmica em muitos casos, em detrimento da hipótese advogada por Radford (1997), segundo a qual, nenhum obstáculo epistemológico pode "resistir" ao efeito da cultura, pois se estamos corretos, a cultura não é uma inconveniência para o conhecimento nem o conhecimento “paira” sobre as culturas. (1997, $\xi 3$, tradução nossa)

Para validar a proposta de que contextos históricos possam ser considerados significativos para o desenvolvimento de conteúdos matemáticos, é preciso, a nosso ver, adaptar o clássico discurso da análise dos fatos históricos para situações de ensino próximas da realidade sociocultural dos estudantes. Essa adaptação, ao mesmo tempo em que preserva a identidade das ocorrências históricas, com seu entorno e contexto sociotemporal, codifica imagens e símbolos antigos e os fazem ressurgir em condições atuais, atribuindo-lhes significados coerentes com a proposta pedagógica concebida a partir do percurso histórico. Trata-se, portanto, de aproveitar o contexto histórico para dele retirar e adaptar os aspectos que interessam ao aprendizado de determinado conteúdo.

Assim, nos afastamos de Bachelard e da noção de obstáculo epistemológico e nos aproximamos dos elementos destacados por Goodman para a composição de contextos. Enfatizar elementos, compor e recompor, ordenar, suprimir e completar e, por fim, deformar, são estas as ações que julgamos apropriadas para justificar a contextuação de conceitos pela via da História da Matemática. Novamente neste ponto destacamos a importância que as narrativas desempenham na constituição desses contextos.

Aceitar que a construção conceitual pode ser estimulada a partir do recurso à História da Matemática implica em entender que a evolução do conhecimento matemático, construído e acumulado durante tantos anos, quando reproduzida na escola, é capaz de incitar a produção de novos significados conceituais. Partindo dessa premissa, o próximo passo é selecionar estratégias pedagógicas de modo que a História configure-se, de fato, como contexto metodológico de trabalho para o desenvolvimento dos conteúdos. Nesse caso, não se pode 
esperar que a História da Matemática, por si só, apresente-se como caminho sólido por onde são apresentados os conceitos, pois, como afirma Motta (2006),

[...] as abordagens ingênuas que buscam transpor passagens históricas diretamente para a sala de aula permanecem em nível superficial e não alcançam as situações didáticas que são significativas para a aprendizagem. (p.109)

Vale, isso sim, pensar no recurso à História da Matemática enquanto elemento importante na composição de uma metodologia de trabalho que seja eficiente no objetivo maior de atribuir significados aos conceitos e de enxergá-los em suas múltiplas relações com outros, com outros significados que de alguma forma a eles se relacionam, formando assim a grande teia conceitual.

A construção dessa teia conceitual passa pela necessidade de o professor mobilizar as competências típicas de sua ação pedagógica, descritas por Machado (2009) e destacadas anteriormente. Retomemos uma delas, a competência relativa à construção de narrativas fabulosas, sobre a qual destaca o autor:

De fato, o significado em qualquer tema, sempre é construído por meio de uma história, de uma narrativa bem arquitetada [...]. Um professor competente, de Matemática ou de qualquer outro tema, deverá necessariamente ser um bom contador de histórias: preparar uma aula é construir uma narrativa pertinente. ( p. 72 e 73 )

A compreensão de que o conhecimento se constrói quando diferentes significados conceituais são associados entre si, não exclui, de forma alguma, a necessidade de que sejam escolhidos e cumpridos traçados determinados, lineares muitas vezes, sobre a imensa rede conceitual. Na escolha desses traçados enxergamos a possibilidade de que o recurso à História da Matemática venha a ser um dos aspectos, nunca o único, a ser levado em conta. Também no caso desse recurso, vislumbramos a necessidade da produção de narrativas bem construídas, com roteiros elaborados a partir dos elementos históricos que, ao serem relacionados entre si, permitem o transporte dos significados conceituais desde o professor que as elabora até os alunos que as vivenciam.

De outra maneira, porém no mesmo sentido, Motta (2006) ressalta a importância de agregar o discurso pedagógico da Matemática à produção de significados quando afirma que a reconstrução de conhecimentos já disponíveis na História da Matemática exigem o uso de 
aproximações possíveis entre termos matemáticos e termos da língua materna, o apoio de metáforas ilícitas que sejam formas de aproximação ao que o texto diz e até o apoio de erros conceituais. (p. 113)

Aproximações possíveis entre termos matemáticos e termos da língua materna, e a criação de situações de ensino em que a composição de enredos estimulam a compreensão desejada, são características típicas de uma narrativa.

A composição de uma narrativa a partir da qual seja possível a apresentação e o desenvolvimento de conteúdos matemáticos estimula o recurso à Historia da Matemática. Nessa medida, devemos identificar passagens históricas na evolução de conceitos matemáticos que, quando recontados, metaforizados e colocados em confronto com preceitos atuais, auxiliem a composição de uma narrativa capaz de "carregar" os significados conceituais que selecionamos para nossos alunos. Assim, acreditamos, não se trata de apresentar a nossos alunos a Matemática pela via da História, e sim, compor conjuntos de circunstâncias que favoreçam a construção de contextos a partir do legado deixado pela História da Matemática.

\subsubsection{UM EXEMPLO DE CONTEXTO DE ENSINO ELABORADO A PARTIR DE ELEMENTOS DA História da MATEMÁtica: A CONSTRUÇão dOS NÚMEROS REAIS.}

No ensino da Matemática identificamos algumas polarizações que são superadas à medida que etapas de aprendizagem vão sendo cumpridas. Um desses casos refere-se à polarização entre o discreto e o contínuo.

Começando no Ensino Fundamental, o registro das relações parte-todo com grandezas discretas, como, por exemplo, quantidades de parafusos, pessoas ou bolinhas, gera dificuldades de natureza diferentes daquelas geradas por relações envolvendo medidas de comprimentos ou de massas, que são grandezas contínuas. Os procedimentos de contagem com os quais a criança se envolve, em certo momento ampliam o espectro com a introdução de procedimentos de medida e seu consequente registro numérico.

As frações são um dos primeiros contatos das crianças com a ideia de contínuo, se bem que aquelas que envolvem quantidades contínuas são representadas através de desenhos que mascaram a questão da continuidade. Um dos quatro pedaços iguais de uma barra de chocolate representa $1 / 4$ da mesma forma que duas pessoas destacadas de um grupo de oito 
pessoas. A representação decimal de um número fracionário é o detonador da noção de continuidade.

Frações escritas na forma de razões entre números inteiros reforçam, de certa forma, a aparente oposição entre discreto e contínuo, na medida em que é mais comum observarmos crianças com dificuldades na escrita e interpretação de frações inteiras ou impróprias $\left(\frac{4}{2}, \quad 3 \frac{1}{4}, \quad 1 \frac{4}{5}\right.$ etc. $)$ do que das ordinárias, de modo geral.

Brolezzi (1997), em seu trabalho sobre o que denominou "tensão discreto-contínuo", assinala:

Dessa maneira de encarar o discreto e o contínuo como realidades completamente disjuntas surgem consequências graves para o ensino, e perdese muito da riqueza da Matemática. Verifica-se assim a existência de um problema no ensino de Matemática elementar, ocasionado pela tendência de se optar ora pelo discreto ora pelo contínuo, fazendo sucumbir um em função do outro. ( p. 6)

Essa coexistência aparentemente difícil entre discreto e contínuo acompanhará os alunos nas séries futuras, transparecendo, mais tarde, na compreensão, por exemplo, da existência dos números irracionais, de expansão decimal infinita e não periódica como $\sqrt{3}$ ou $\pi$. Apenas a compreensão da densidade e da continuidade do conjunto dos números Reais poderá colocar ponto final na aparente polêmica entre discreto e contínuo, visto que, daí em diante, a convivência entre ambos os campos parecerá harmônica.

A História da Matemática registra vários momentos em que a relação discreto $X$ contínuo esteve na berlinda, e uma maneira de estimular os alunos na construção do campo real pode consistir em recuperar eventos históricos e reconfigurá-los à luz de nosso interesse atual, compondo, dessa maneira, contexto significativo para o tratamento conceitual.

Uma referência histórica a qual podemos recorrer refere-se aos enunciados formulados por Zenão de Eleia, por volta do ano 500 a.C. As situações paradoxais propostas por Zenão atingiram diretamente, em seu tempo, as concepções anteriores acerca dos conceitos de movimento e de tempo, concepções estas que, de certa forma, também povoam o imaginário de estudantes dos derradeiros anos do Ensino Fundamental nos dias de hoje.

A problematização sugerida por Zenão em seus paradoxos residia na impossibilidade de intervalos de espaço e de tempo serem constituídos por uma infinidade de elementos 
individuais separados uns dos outros, isto é, na consideração de que tempo e espaço são grandezas descontínuas. Os alunos sabem que Aquiles alcançará a tartaruga, que um corredor pode percorrer o estádio, e que uma seta em voo se move, mas não sabem identificar os elementos que permitiriam apontar as incoerências nas conclusões que são levados a tirar por intermédio dos paradoxos.

As atividades que propomos aos alunos a respeito da construção do campo Real partem da condição de que existem comprimentos que não podem ser perfeitamente representados por números escritos em sua expansão decimal, uma vez que, neste caso, apresentam infinitas casas decimais sem periodicidade. Tais números, irracionais, podem ser localizados com precisão na reta numérica apenas com o uso de régua e compasso, por intermédio de construções geométricas. Apresentamos a seguir algumas atividades em que estão presentes a condição aqui expressa.

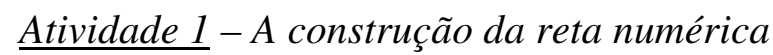

1) Desenhe uma reta numérica assinalando os pontos referentes aos números inteiros, de $-5 a+5$.

Em seguida, utilizando apenas régua e compasso, desenhe um quadrado de lado igual a 1 unidade, com um dos lados apoiado sobre a reta numérica, de modo que dois de seus vértices consecutivos coincidam, respectivamente, com os pontos $0 e+1$.

2) Observando o quadrado que desenhou, responda: quantas unidades mede a diagonal?

3) Responda como você pode proceder para localizar, na reta numérica, a posição exata dos seguintes números reais:
a) $\sqrt{2}$
b) $2 \sqrt{2}$
c) $1+\sqrt{2}$
d) $13+\sqrt{2}$

A determinação da medida da diagonal de um quadrado de lado igual a 1 unidade serviu, na atividade descrita, como elemento motivador para a localização na reta numérica de vários números irracionais, compostos a partir de adições ou multiplicações de racionais por $\sqrt{2}$.

O desenvolvimento do conjunto de atividades permitiu aos alunos tomarem contato com as ideias gerais dos pitagóricos a respeito dos mônadas e também com as proposições de Zenão que estimularam o combate a tais concepções. Também nesse caso, destacamos a importância desempenhada pelas narrativas enquanto elemento capaz de atribuir e transportar 
significados conceituais, constituindo-se, dessa maneira, em autênticos pilares do edifício contextual.

No ato de relatar passagens históricas, resignificando-as e relacionando-as aos procedimentos geométricos adotados pelos alunos na construção da reta numérica, localizamos os elementos apontados por Goodman (1995). Composição e decomposição, por exemplo, o primeiro aspecto apontado por Goodman, têm presença assegurada na trama narrativa que estabelecemos para a condução dos significados conceituais, visto ser necessário, nesse sentido, identificar e valorizar personagens, cenários, enredos, e agrupá-los coerentemente de modo a compor paisagem intelectual sobre a qual podemos vislumbrar o percurso que imaginamos.

Especialmente na composição de contextos de ensino com base na reelaboração de aspectos da História da Matemática, notamos a forma imbricada como os elementos destacados por Goodman(1995) se apresentam, de maneira que a presença de um deles praticamente exige a presença dos demais. Partindo da composição e decomposição, evidencia-se a necessidade de, por um lado, destacar os personagens e os papéis que representarão na trama que se elabora, e, por outro lado, na sequencialização das ações que envolverão personagens e cenários. Nesse processo notamos a presença dos elementos referentes a enfatização e a ordenação.

A construção da reta numérica provavelmente nunca foi realizada nos tempos de Zenão e dos pitagóricos, senão por outros motivos, pelo menos devido ao desconhecimento acerca dos números negativos. Uma atividade que relaciona, nos dias atuais, a construção da reta numérica às antigas concepções acerca da descontinuidade, exige a mobilização dos elementos relativos a supressão e completação bem como o recurso à deformação, na medida em que enredos são desenhados a partir dos relatados pela história, e reconfigurados à luz da composição do contexto de ensino.

\section{5. ConteXto E A INTRAdiscipllanARIdAde nO ENSINO da MATEMÁtiCA - E ALGO SOBRE A TRANSDISCIPLINARIDADE}

O ensino no Ocidente, em todos os níveis, organizou-se, a partir do século XIX, sobre a forma multidisciplinar, especialmente pelo impulso dado às pesquisas científicas. Assim, à medida que as universidades passaram a organizar sua produção científica com base na 
especialização exigida pela pesquisa interna, tal busca pela especialização refletiu-se no ensino, estimulando a organização de currículos sob a forma de disciplinas independentes. A constituição curricular esteve, portanto, atrelada às contingências do desenvolvimento científico do final do século XIX e primeira metade do século XX, relacionando-se, dessa forma, às circunstâncias sociais do período. Isto significa, como afirma Morin (2001), que $a$ disciplina nasce não apenas de um conhecimento e de uma reflexão interna sobre si mesma, mas também de um conhecimento externo (p. 105).

A importância das disciplinas é indiscutível, pois são elas que destacam os objetos de estudo e os analisam, fornecendo os subsídios necessários não apenas à compreensão do escopo de conteúdos das disciplinas, mas também ao desenvolvimento de competências pessoais que, segundo Machado (2009), envolvem a capacidade de compreender e de se expressar, de argumentar para decidir e de contextuar para imaginar.

Todavia, o foco colocado apenas sobre a organização disciplinar estimula a hiperespecialização do sujeito, acarretando o risco de o aprendizado realizar-se como fim em si mesmo, negligenciando-se as ligações entre os objetos de uma e outras disciplinas, bem como a relação entre objetos disciplinares e não disciplinares. A possibilidade de enxergarmos o trabalho pedagógico priorizando, por um lado, relações entre objetos da mesma disciplina e, por outro, relações entre estes objetos e outros, não disciplinares, remete a dois tipos de integração, respectivamente, intradisciplinar e transdisciplinar. Analisemos tais possibilidades.

Os conteúdos internos de uma disciplina são organizados e sequenciados nos planejamentos curriculares a partir de algum critério. No caso da Matemática, especialmente, a clássica seleção e organização dos conteúdos é realizada com base no sequenciamento cartesiano que se origina no mais simples e ruma em direção ao mais complexo. Já questionamos tal organização curricular, justificando que ela é tributária de uma concepção inadequada acerca de como atualmente o conhecimento é construído. As relações entre significados conceituais, que caracteriza a concepção de que o conhecimento é construído com base na metáfora da rede de significados, devem ser estimuladas em todos os níveis, uma vez que tais relações se estabelecem tanto interna quanto externamente aos conceitos disciplinares. A organização cartesiana dos conteúdos, portanto, contribui para abafar a evidência das relações entre significados conceituais existentes internamente à disciplina. Assim, o respeito à concepção do conhecimento construído como uma rede cujos nós são os 
significados e cujas ligações são estimuladas pelas narrativas rompe, de início, com a fragmentação dos conteúdos que se observa na organização disciplinar.

Denominamos contexto intramatemático ao conjunto de circunstâncias que selecionamos e que permitem organizar percursos sobre a rede conceitual, relacionando significados conceituais internos à própria disciplina. $\mathrm{O}$ principal, mas não único critério para a seleção dos componentes do conjunto de circunstâncias nesse caso, é a conectividade lógica entre os significados conceituais, comentada a seguir.

Ao analisar uma lista de conteúdos matemáticos, um professor perceberá a existência de relações entre eles, algumas facilmente identificáveis e outras, nem tanto. São claras as relações entre alguns conceitos internos à geometria, como as que existem, por exemplo, entre o cálculo de áreas de polígonos e a aplicação do teorema de Pitágoras. Por outro lado, não são tão evidentes as relações entre a álgebra das matrizes e as transformações isométricas de polígonos no plano cartesiano. De qualquer forma, com maior ou menor dificuldade, é possível localizar pontos de convergência entre conceitos internos à Matemática, de maneira que o significado de um deles pode ser complementado a partir do significado de outros. São estes pontos de convergência que definem a conectividade lógica de grupos de conceitos disciplinares, ou seja, a possibilidade de, em trânsito interno à própria disciplina, relacionarem-se de modo a estimular a ampliação dos feixes de significados de seus elementos.

\subsubsection{UM EXEMPLO DE CONTEXTO INTRAMATEMÁTICO DE ENSINO: AS MATRIZES}

Analisamos anteriormente exemplo de situação de ensino para a apresentação das matrizes com base em algumas de suas aplicações cotidianas. No caso, o viés adotado foi o da representação de imagens por intermédio de unidades de informação, os bits.

Na sequência deste capítulo, durante as conclusões, recorreremos a Popper (2009) e a Machado (2009) para justificar a necessidade acerca da diversificação dos contextos de ensino. Adiantando um pouco tal discussão, apresentamos a seguir as operações entre matrizes com base em outro contexto, diferente daquele em que as apresentamos anteriormente, voltado para algumas relações internas à própria Matemática.

Na preparação do roteiro da atividade, procuramos identificar relações de proximidade entre significados de conceitos matemáticos de mais de um bloco de conteúdos. Tendo as 
matrizes como referência, encontramos na representação de polígonos no plano cartesiano uma dessas possibilidades de aproximação, na medida em que podemos registrar em linhas e colunas de uma matriz as coordenadas dos vértices dos polígonos. Além disso, associamos a translação dos polígonos no plano cartesiano à adição entre a matriz original, contendo as coordenadas dos vértices, e uma matriz operatória com a indicação da translação a ser realizada. Estas são, portanto, relações entre significados internos à Matemática, que estimulam a construção da rede conceitual acerca do conhecimento matemático como um todo.

Problema 1 - Observe os dois polígonos representados no plano cartesiano:

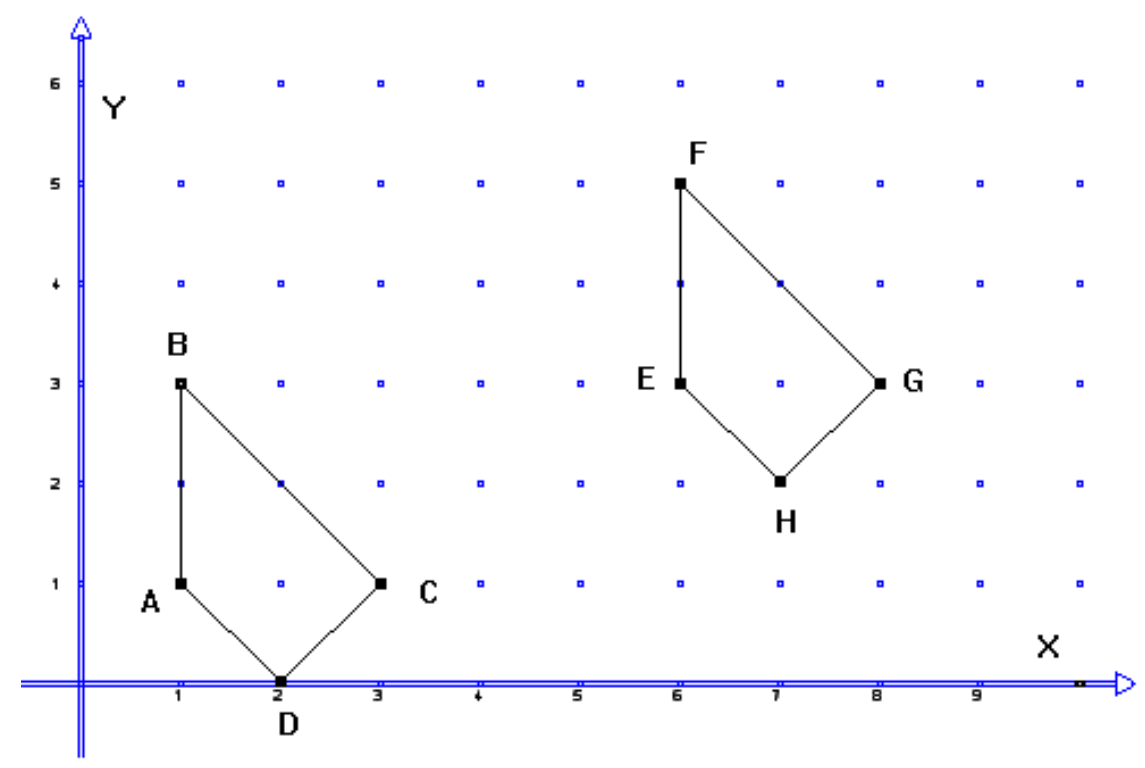

Esses dois polígonos são congruentes, e podemos considerar que o polígono EFGH é uma translação do polígono $A B C D$, isto é, EFGH foi obtido a partir de duas movimentações de ABCD, sendo uma na horizontal e outra na vertical. Responda:

a) Quantas unidades na horizontal e quantas unidades na vertical ABCD deve ser deslocado para que, ao final, coincida com EFGH?

b) Represente em uma matriz $\boldsymbol{A}_{(4 \times 2)}$ as coordenadas dos vértices do polígono $A B C D$, de maneira que cada linha da matriz contenha coordenadas de um ponto, com a abscissa na primeira coluna e a ordenada na segunda coluna.

c) Represente em uma matriz $\boldsymbol{B}_{(4 \times 2)}$ as coordenadas dos vértices do polígono EFGH, de maneira que cada linha da matriz contenha coordenadas de um ponto, com a abscissa na primeira coluna e a ordenada na segunda coluna. 
d) Escreva uma matriz $\boldsymbol{C}_{(4 x 2)}$ de tal forma que $\boldsymbol{A}+\boldsymbol{C}=\boldsymbol{B}$.

Problema 2 - Na representação seguinte de um plano cartesiano podemos observar três triângulos congruentes. $O$ triângulo $A B C$ pode ser transladado até coincidir com o triângulo $D E F$, que por sua vez, se transladado, poderá coincidir com o triângulo GHI.

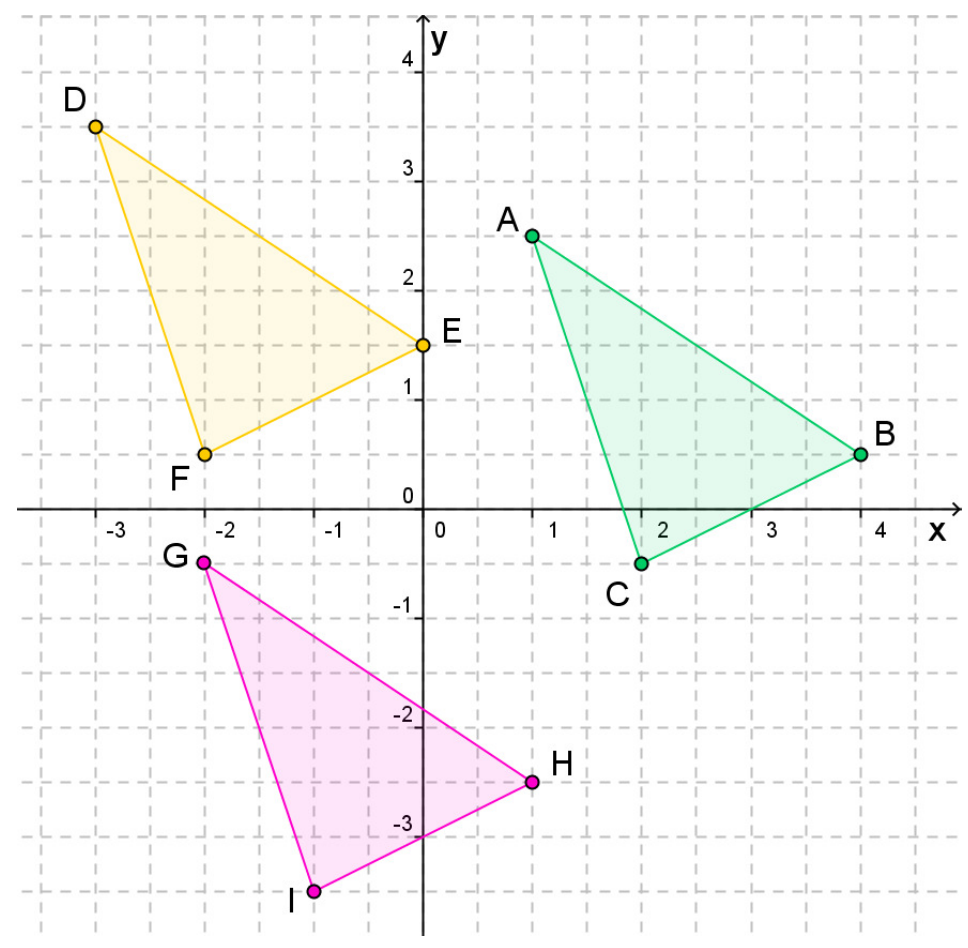

a) Quantas unidades horizontais e quantas unidades verticais são necessárias para uma translação do triângulo $A B C$, a fim de que ele, ao final, coincida com o triângulo DEF?

b) Quantas unidades horizontais e quantas unidades verticais são necessárias para uma translação do triângulo DEF, a fim de que ele, ao final, coincida com o triângulo GHI?

c) Quantas unidades horizontais e quantas unidades verticais são necessárias para uma translação do triângulo $A B C$, a fim de que ele, ao final, coincida com o triângulo GHI?

d) Escreva uma matriz $3 \times 2$ para cada triângulo, de maneira que cada linha da matriz contenha coordenadas de um vértice do triângulo, com a abscissa na primeira coluna e a ordenada na segunda coluna. Denomine a matriz referente ao triângulo $A B C$ pela letra $M$, a matriz referente ao triângulo DEF pela letra $N$, e a matriz referente ao triângulo GHI pela letra $P$.

e) Escreva uma matriz $Q$, tal que $M+Q=N$ 
f) Escreva uma matriz $R$, tal que $N+R=P$

g) Escreva uma matriz $T$, tal que $M+T=P$

\subsubsection{OUTRO EXEMPLO DE CONTEXTO INTRAMATEMÁtico DE ENSINO: OS NÚMEROS COMPLEXOS}

Consideremos como exemplo o caso dos números complexos, normalmente apresentado aos alunos na série final do Ensino Médio. Comentários comuns dos professores fazem referência à dificuldade em identificar aplicações cotidianas para esse tipo de número, de maneira que as aulas tornam-se pouco interessantes para os alunos. De fato, números complexos, não reais, não fazem parte de qualquer experiência cotidiana de adolescentes de Ensino Médio, mas não devem, por isso, serem deixados fora da grade curricular. Podemos, isto sim, apresentá-los aos nossos alunos com base em rico contexto de ensino, elaborado a partir das relações entre significados que conceitos próprios aos números complexos estabelecem com conceitos de outros blocos de conteúdos, configurando, dessa forma, um contexto intramatemático. Nesse sentido, comentemos sobre uma possível sequência de atividades.

Números complexos não exprimem resultados de contagens e nem representam quantidades; além disso, não faz muito sentido ordená-los, e usá-los como elemento básico de codificação é, no mínimo, estranho. Assim, de acordo apenas com os usos que os alunos conhecem até então, um complexo não mereceria receber o título de "número".

Boa parte do tradicional estudo dos complexos no Ensino Médio fica restrita ao tratamento das operações entre eles, de modo semelhante ao qual é submitida a criança quando começa a tomar contato com as operações entre números naturais. Se o estudo das operações pelas crianças, nesse caso, ocorre sobre o contexto de suas práticas cotidianas contagem de pontos nos jogos, cálculo do troco na cantina etc. - o caso dos números complexos, nesse sentido, é bastante diverso.

Retomando as premissas estabelecidas anteriormente acerca do caminho do conhecimento e do papel das abstrações, como podemos compreender o estudo dos números complexos no Ensino Médio?

De modo bastante simplificado, podemos entender que o conhecimento dos alunos acerca dos números reais é o patamar inicial para as necessárias abstrações que precisarão realizar a fim de construírem significados acerca dos complexos. Se isto é válido, convém 
questionar quais são as abstrações necessárias para que seja atingido o nível superior de conhecimento concreto, e quais são os significados conceituais que, esperamos, serão agregados àqueles anteriormente construídos?

A escolha do caminho das necessárias abstrações envolve tomar a decisão de apresentar aos alunos a "nova" função dos números complexos. Ou seja, convém, de início, deixar claro que os complexos não são importantes enquanto números, como os alunos conhecem até então, e que sua importância reside na possibilidade serem utilizados como "operadores", capazes de gerenciar transformações isométricas no plano. Compreender e operar com os complexos com este objetivo - gerenciar rotações, reflexões e translações formará a etapa de concretude superior, além da compreensão dos Reais. O contexto sobre o qual se desenvolverá o estudo será formado, unicamente, pelas múltiplas relações de significado entre os conceitos matemáticos ou, em outros termos, procedimentos matemáticos serão os elementos que alimentarão as abstrações necessárias.

O ponto de partida para o estudo dos complexos pode ser o conhecimento que os alunos possuem acerca da resolução de problemas envolvendo números Reais. Para tanto, podemos recuperar a fórmula de Cardano para a resolução de determinado tipo de equação polinomial de $3^{\circ}$ grau, e propor que resolvam algumas das clássicas situações envolvendo a raiz quadrada de um número negativo, como, por exemplo, estes:

\section{$\underline{\text { Atividade } 1}$}

1) Uma das raízes de uma equação de $3^{\circ}$ grau do tipo

$$
y^{3}+M y+N=0
$$

pode ser obtida através da expressão:

$$
y=\sqrt[3]{-\frac{N}{2}+\sqrt{\frac{N^{2}}{4}+\frac{M^{3}}{27}}}+\sqrt[3]{-\frac{N}{2}-\sqrt{\frac{N^{2}}{4}+\frac{M^{3}}{27}}}
$$

Encontre uma raiz da equação $y^{3}-3 y-2=0$.

2) Um marceneiro quer construir duas caixas, uma com a forma de um cubo de aresta x, outra com a forma de um paralelepípedo com a base retangular, de lados $3 \mathrm{~m}$ e $5 \mathrm{~m}$, e de altura 
igual à altura do cubo. $O$ valor de $x$ deve ser escolhido de tal forma que o volume do cubo seja $4 \mathrm{~m}^{3}$ maior do que o do paralelepípedo.

a) Escreva a equação que traduz a exigência a ser satisfeita pelo valor de $x$.

b) Verifique diretamente na equação dada que $x=4$ é uma raiz, ou seja, fazendo $x=4 \mathrm{~m}$, temos o cubo com volume $64 \mathrm{~m}^{3}$ e o paralelepípedo com volume $60 \mathrm{~m}^{3}$.

c) Use a fórmula de Cardano-Tartaglia para determinar as raízes da equação do item a. A que conclusão você chega?

Problemas como estes mostram, por um lado, a impossibilidade de obter-se as raízes quadradas de números negativos e, por outro, a necessidade de se relacionar os conhecimentos estabelecidos pela fórmula de Cardano e pela solução real do problema. De um modo ou de outro, imaginamos que a busca pela superação dessas dificuldades possa servir de motivação para a apresentação dos números complexos aos nossos alunos.

Se a apresentação é convincente, a sequência do percurso não pode ficar restrita à utilização dos complexos como recurso para a resolução de equações polinomiais, ou ao estudo das propriedades das operações entre eles. Rapidamente é necessário atingir o degrau para o significado mais amplo dos complexos, que reside na possibilidade de serem gerenciadores de transformações isométricas no plano. Para tanto, a apresentação do plano de Argand-Gauss e a associação entre este plano e a reta Real passa a ser prioridade.

De início, podemos mostrar aos alunos o significado de multiplicar um número real por um número real negativo, como por exemplo, 3.(-2)



Nesse caso, rotacionamos de $180^{\circ}$ um vetor associado ao número 3 , além de dobrarmos seu módulo. O passo seguinte pode consistir no questionamento aos alunos sobre 
como podemos indicar uma rotação de $90^{\circ}$ do vetor original associado ao número 3. Espera-se que os alunos concluam que é necessário multiplicar 3 por um fator que seja a raiz quadrada do fator anterior, que produziu a rotação de $180^{\circ}$. Ou seja, espera-se que respondam $\sqrt{-2}$, pois



Dessa ideia inicial poderemos evoluir rapidamente para a apresentação da unidade imaginária (i) e para a importância de multiplicarmos um número real qualquer por múltiplos e submúltiplos dessa unidade, produzindo, assim, rotações e ampliações/reduções nos módulos dos vetores. Em seguida, podemos considerar a multiplicação de números complexos, não reais, por imaginários puros, como por exemplo, $(-2+3 i) .(i)$, mostrando a rotação e a ampliação do módulo do vetor que parte de $(0,0)$ e atinge $(-2,3)$. Isto pode ser feito por intermédio de problemas como este, por exemplo:

\section{Atividade 2}

Multiplicando um número complexo $z$, não nulo, pela unidade imaginária (i), o vetor associado a $z$ rotaciona $90^{\circ}$ em torno da origem e no sentido anti-horário.

Veja no exemplo que:

$z=-2+3 i$

$z . i=(-2+3 i) \cdot i=-2 i+3 i^{2}=-3-2 i$

Desenhe em seu caderno o plano de Argand-Gaus, e represente nele os vetores associados aos números $\boldsymbol{w}=1+3 i$, e - 2.w.i, ou seja, o produto de $\boldsymbol{w}$ por -2 e pela unidade imaginária.




Insistimos na rotação dos vetores, embora seja necessário também discutir como os alunos as outras transformações - translação e reflexão. Para estes casos, podemos apresentar problemas envolvendo a adição vetorial e a multiplicação de complexos por reais, como, por exemplo, nas situações seguintes:

\section{$\underline{\text { Atividade } 3}$}

1) Observe o plano complexo com os vetores associados aos números $z_{1}=3+2 i$ e $z_{2}=-1-i$.

Determine o número complexo $z_{3}$

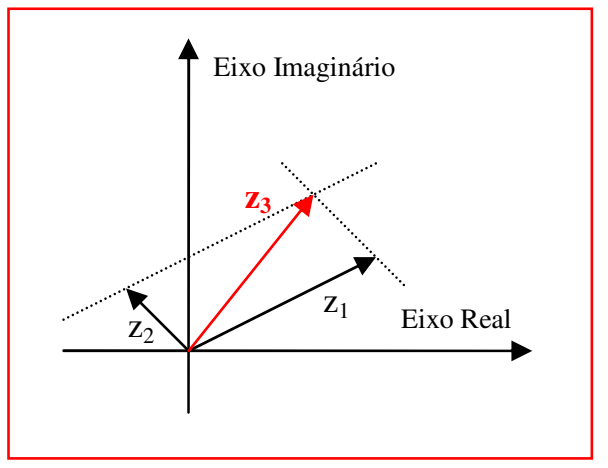

2) Observe o plano de Argand-Gauss com o vetor associado ao número complexo $\boldsymbol{u}$ e o vetor associado à soma $\boldsymbol{u}+\boldsymbol{v}$.

a) Quais são as coordenadas do afixo do número $\boldsymbol{v}$ ?

b) Desenhe o plano de Argand-Gauss em seu caderno e represente nele os vetores associados aos números $\boldsymbol{u}, \boldsymbol{v} e \boldsymbol{u}+\boldsymbol{v}$.

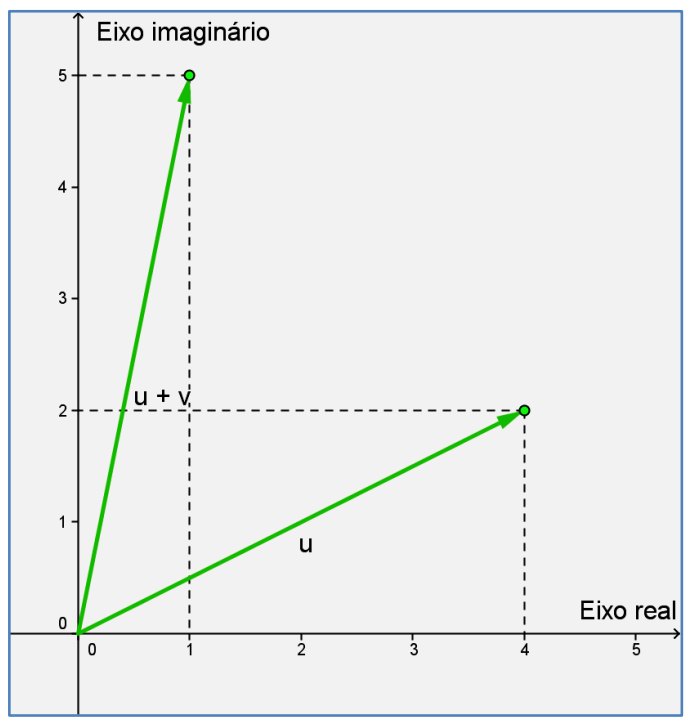

3) Considere o vetor que podemos associar ao número complexo $\boldsymbol{v}=\mathbf{2} \boldsymbol{i}$, representado no plano de Argand-Gauss. Esse vetor forma determinado ângulo $\theta$ com o eixo real.

Determine, em função de $\theta, o$ ângulo formado entre a orientação positiva do eixo real e o número
a) $2 v$
b) i.v
c) $(-1) \cdot v$
d) -2.i.v

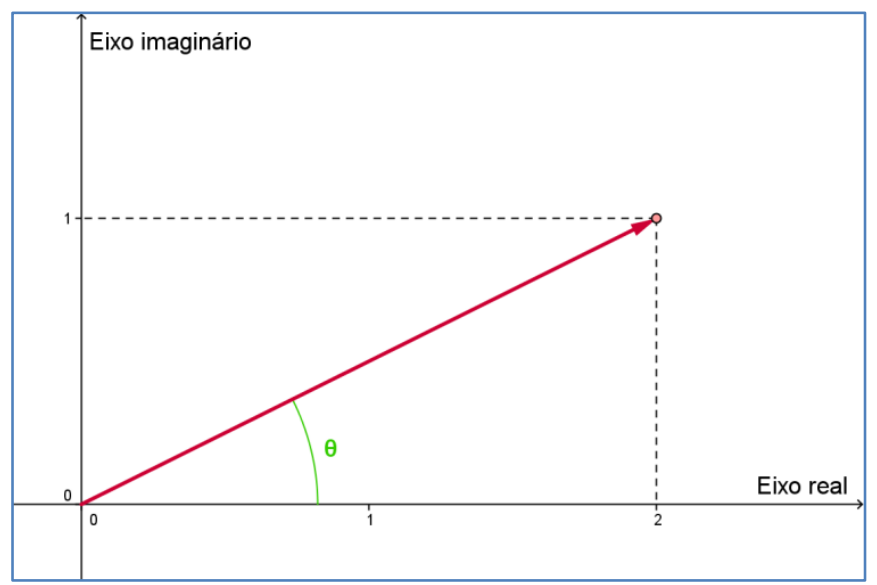


Retomando as rotações, trata-se agora de mostrar como a representação trigonométrica dos números complexos pode nos ajudar a promover rotações de ângulos de quaisquer medidas, e não apenas para ângulos múltiplos de $90^{\circ}$, como fizemos até agora. Temos, assim, uma boa oportunidade de contextualizar o estudo dos complexos com base no desenvolvimento de outro conteúdo matemático: a adição de arcos. Para tanto, poderá ser pedido que os alunos resolvam problemas como este:

\section{$\underline{\text { Atividade } 4}$}

Observe o plano de Argand-Gauss com a representação dos vetores associados a dois números complexos.

a) escreva $z_{1}$ e $z_{2}$ na forma $a+b i$

b) Determine as medidas dos ângulos $\boldsymbol{\alpha}$ e $\boldsymbol{\beta}$ a partir da razão trigonométrica tangente nos triângulos retângulos com catetos de medidas a e b em cada caso.

c) Efetue a multiplicação $z_{1} \cdot z_{2}$

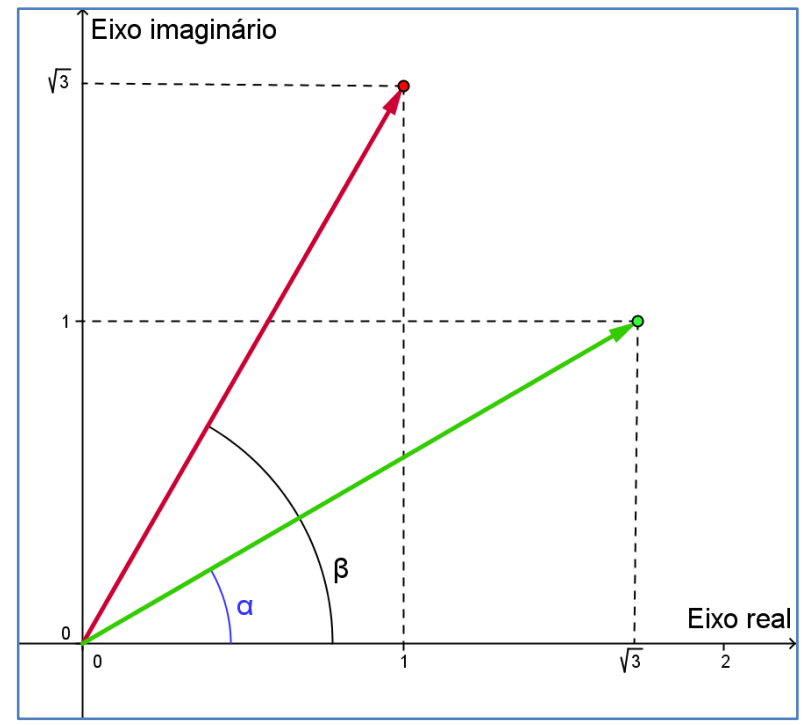

d) Qual é o ângulo que o vetor associado ao produto $z_{1} \cdot z_{2}$ forma com a orientação positiva do eixo real?

e) Efetue a divisão $z_{1}: z_{2}$

Demonstrado que na multiplicação/divisão de complexos multiplicamos/dividimos os módulos e somamos/subtraímos os argumentos principais dos números envolvidos, o próximo passo é nomear como elemento básico das rotações isométricas dos vetores (sem alteração do módulo) o número complexo $\cos \theta+\operatorname{isen} \theta$.

A partir de então, podemos pedir que os alunos desenvolvam situações de rotação de polígonos no plano complexo, utilizando recursos como papel milimetrado, régua, transferidor e calculadora científica, como no caso da atividade seguinte: 


\section{$\underline{\text { Atividade } 5}$}

1) Observe o triângulo ABC representado no plano complexo.

a) Quais são as coordenadas dos vértices desse triângulo?

b) Se rotacionarmos $A B C$ em torno da origem do sistema, ele virá a coincidir com outro triângulo DEF. Desenhe o triângulo DEF e dê as coordenadas de seus vértices.

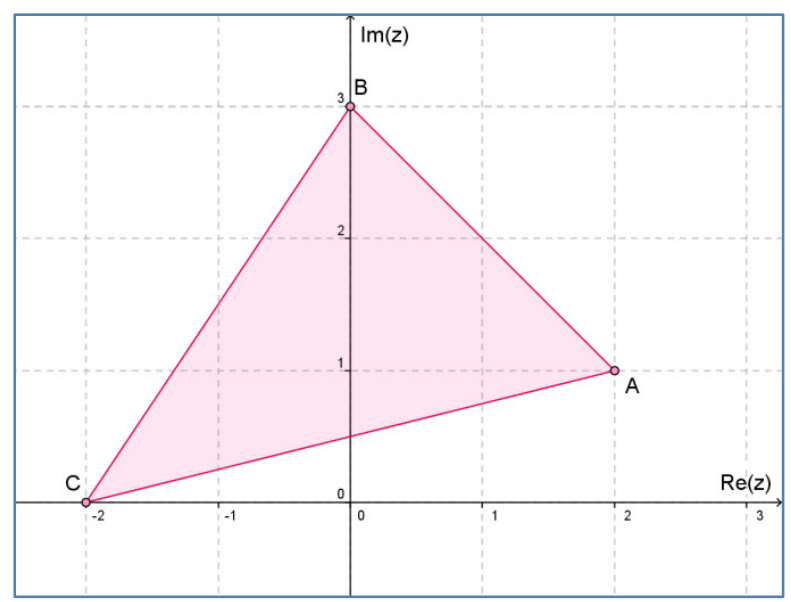

c) Qual é o número complexo que multiplicado por todos os pontos de $A B C$ permite que esse triângulo venha a coincidir com o triângulo DEF descrito no item anterior?

2) O paralelogramo SEMA está representado no plano de Argand-Gauss.

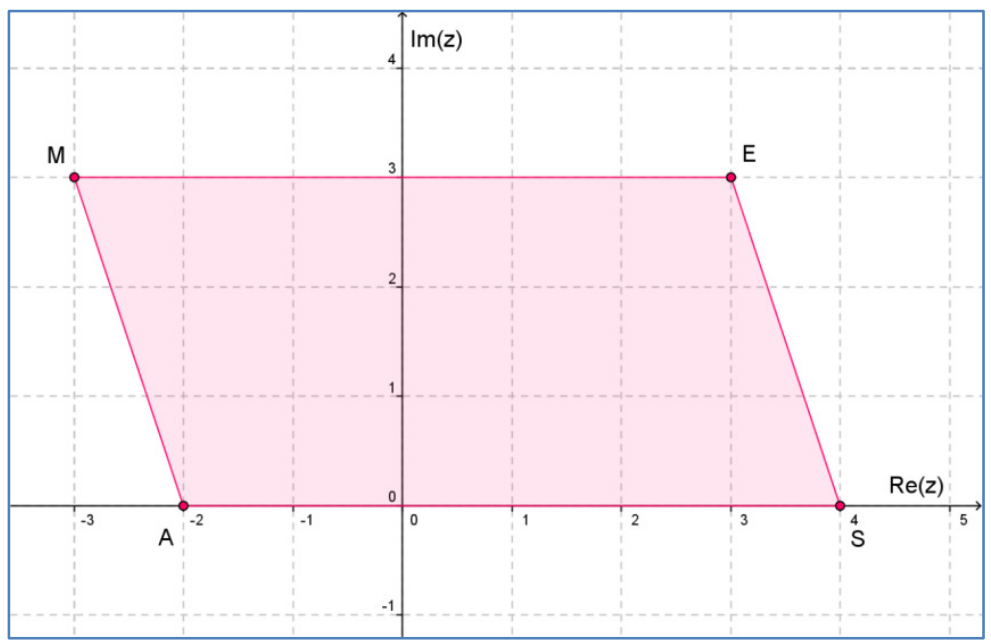


a) Escreva na forma trigonométrica os números complexos associados, respectivamente, aos pontos $S, E, M$ e A.

b) Desenhe o paralelogramo TICO gerado pela rotação de $45^{\circ}$ do paralelogramo SEMA em torno da origem.

c) Escreva a operação matemática que permite que todos os pontos de SEMA sejam rotacionados da maneira descrita no item anterior.

d) Escreva na forma trigonométrica os números complexos associados, respectivamente, aos pontos $T, I$, C e $O$.

$\mathrm{O}$ conjunto de atividades cumprido até o momento permitiu que os alunos se envolvessem com a criação de simulações virtuais envolvendo as transformações sugeridas. Nesse caso, recorrendo ao software livre Geogebra, foram geradas as simulações das quais foram extraídas as imagens apresentadas a seguir.

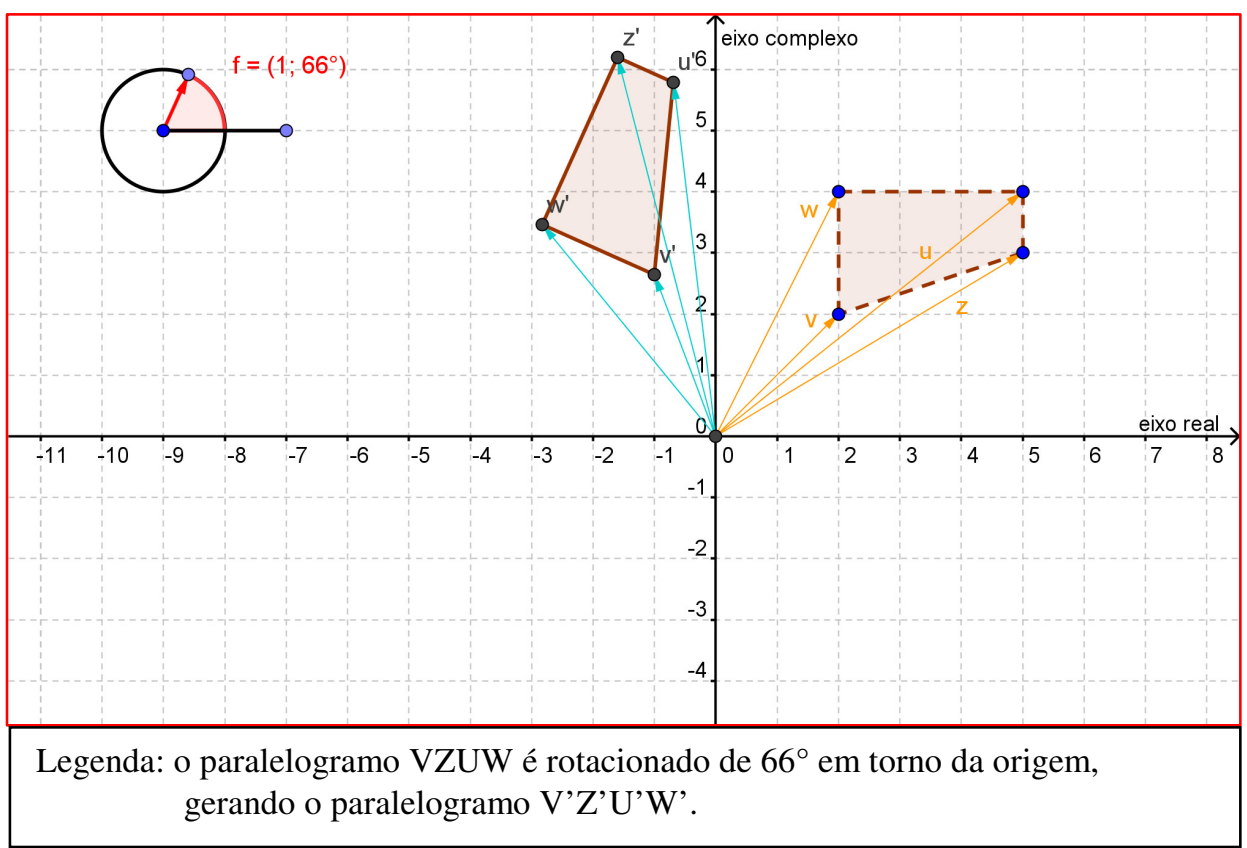




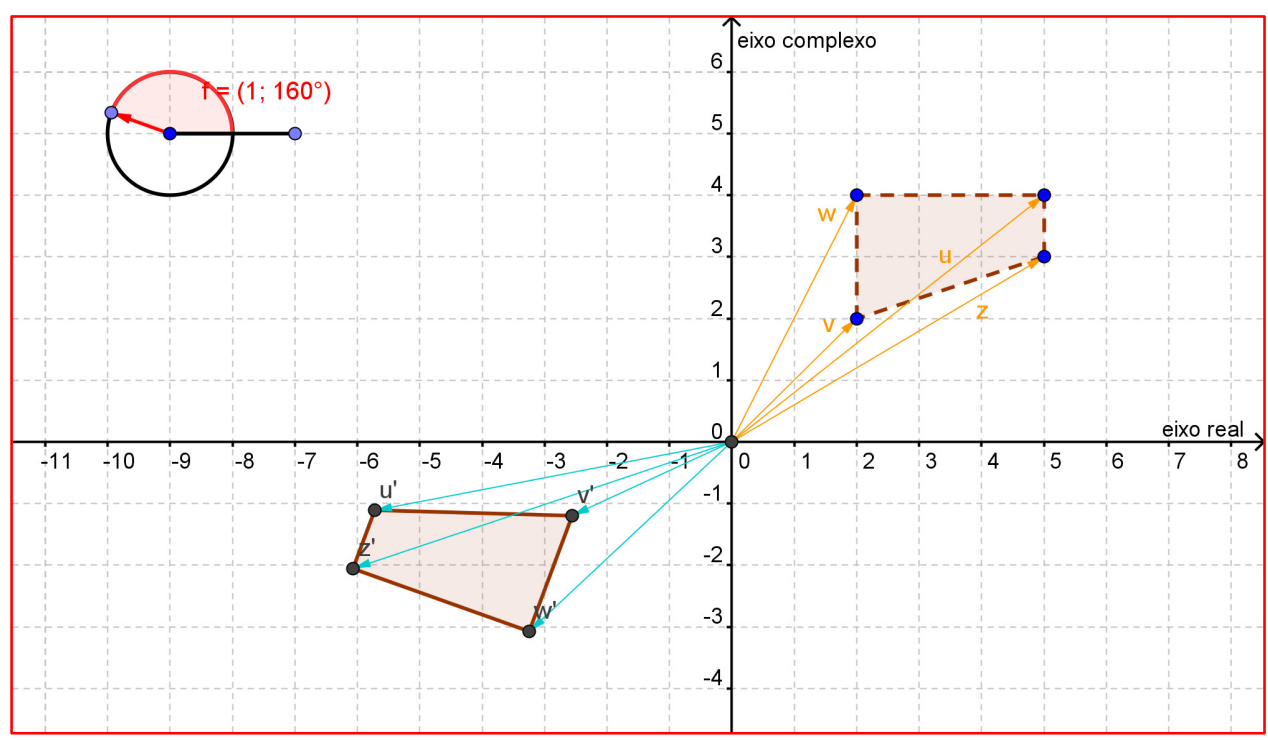

Legenda: o paralelogramo VZUW é rotacionado de $160^{\circ} \mathrm{em}$ torno da origem, gerando o paralelogramo V'Z'U'W'.

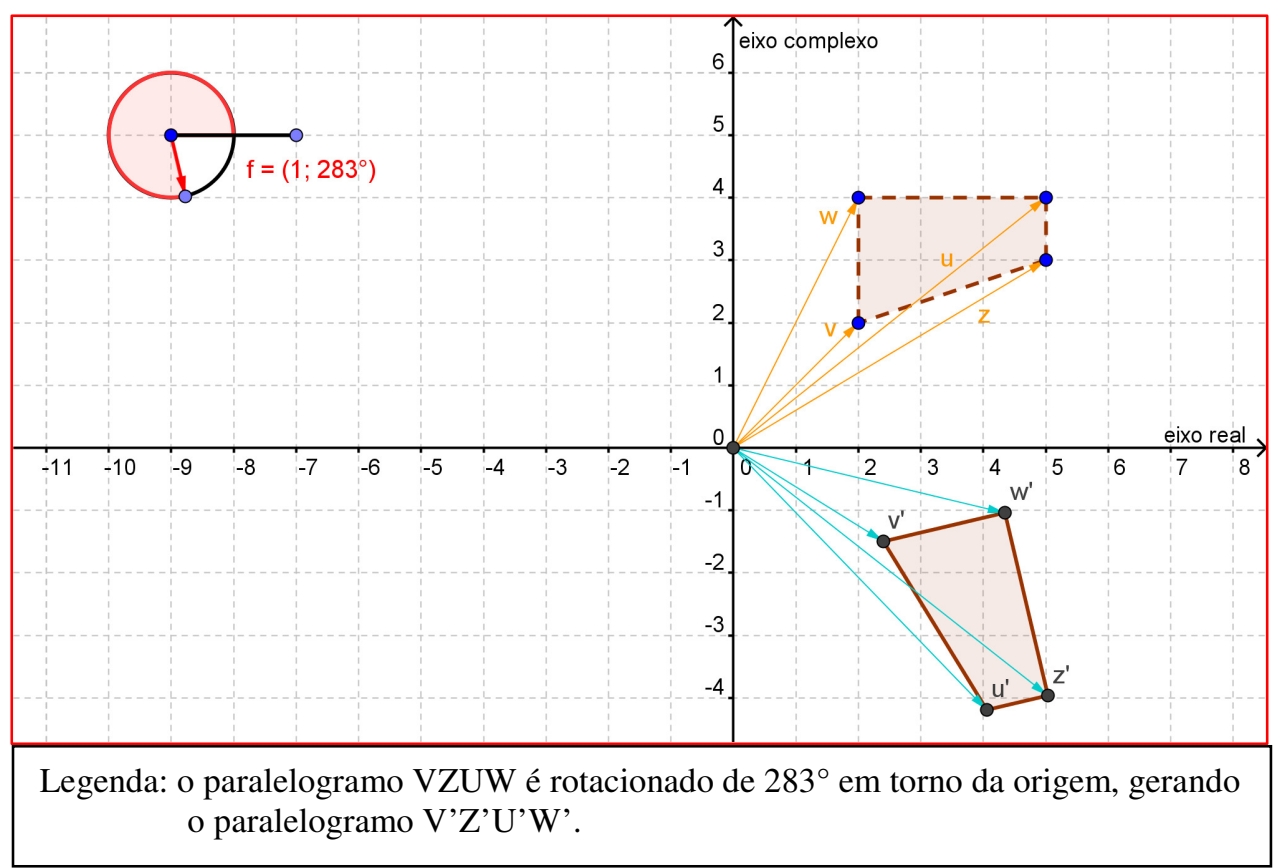

Aprofundando um pouco mais as relações entre significados de conteúdos de diferentes blocos, internamente à Matemática, foi apresentada aos alunos a possibilidade de representar as rotações de afixos de números complexos por intermédio de multiplicação entre matrizes. Observemos o roteiro da atividade referente ao tema. 


\section{$\underline{\text { Atividade } 6}$}

Um número complexo qualquer $\boldsymbol{z}=\boldsymbol{a}+\boldsymbol{b i}$ pode ser representado por uma matriz coluna $\boldsymbol{Z}$ de ordem

2x1, da seguinte forma: $Z=\left[\begin{array}{l}a \\ b\end{array}\right]$

Observe a matriz que representa o número complexo $z=-4+3 i$ :

$$
Z=\left[\begin{array}{c}
-4 \\
3
\end{array}\right]
$$

A matriz R, quadrada de ordem 2, dada por:

$$
\boldsymbol{R}=\left[\begin{array}{cc}
\cos \theta & -\operatorname{sen} \theta \\
\operatorname{sen} \theta & \cos \theta
\end{array}\right]
$$

auxilia a produção de rotações, de ângulos iguais a $\boldsymbol{\theta}$, de pontos no plano quando efetuamos o produto entre as matrizes $\boldsymbol{R}$ e Z. Veja o exemplo do ponto A(2, 2), que sofreu uma rotação de $45^{\circ}$ no sentido anti-horário, em torno da origem.

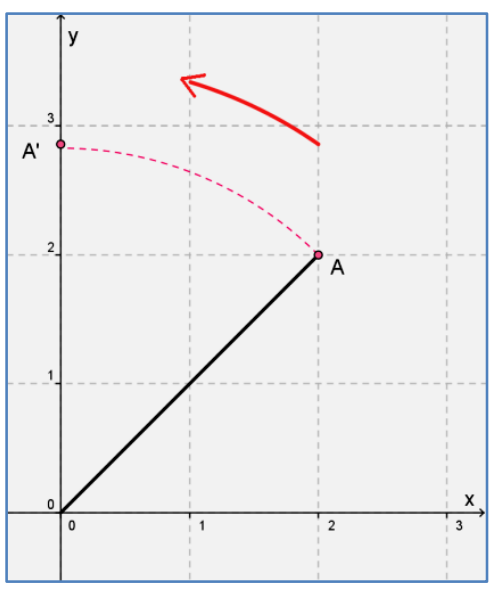

O ponto $A(2,2)$ é o afixo do número complexo $2+2 i$ quando representado no plano de Gauss. Podemos indicar a rotação de $45^{\circ}$ do vetor associado a esse número, no sentido anti-horário, pela multiplicação

$$
R \cdot Z=\left[\begin{array}{cc}
\cos 45^{\circ} & -\operatorname{sen} 45^{\circ} \\
\operatorname{sen} 45^{\circ} & \cos 45^{\circ}
\end{array}\right] \cdot\left[\begin{array}{l}
2 \\
2
\end{array}\right]=\left[\begin{array}{c}
\frac{\sqrt{2}}{2} \cdot 2-\frac{\sqrt{2}}{2} \cdot 2 \\
\frac{\sqrt{2}}{2} \cdot 2+\frac{\sqrt{2}}{2} \cdot 2
\end{array}\right]=\left[\begin{array}{c}
0 \\
2 \sqrt{2}
\end{array}\right]
$$

A matriz resultado nos fornece as coordenadas do ponto A', afixo do vetor rotacionado.

Assim, $A^{\prime}(0,2 \sqrt{2})$.

A matriz $\boldsymbol{R}$ é usada para uma rotação de medida $\boldsymbol{\theta}$ de um ponto $P(a, b)$ no plano, no sentido antihorário, em torno da origem. 
1. Veja o triângulo MEL representado no sistema de coordenadas.

a) Desenhe o triângulo SAC obtido a partir de uma rotação de $315^{\circ}$ do triângulo MEL em relação à origem, no sentido anti-horário

b) Escreva na forma de uma matriz $2 x 1$ as coordenadas do afixo do número complexo identificado pela letra M. Repita o procedimento para os complexos coincidentes com os demais vértices do triângulo MEL.

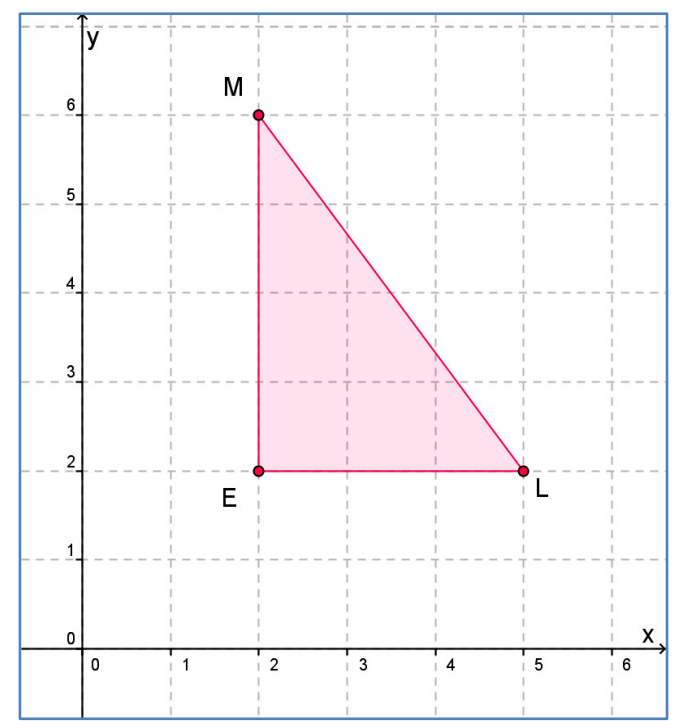

c) Qual a matriz R que poderia ser utilizada como fator de rotação do triângulo MEL de maneira que venha a coincidir com o triângulo SAC?

d) Efetue a multiplicação $R x E$, onde $R$ é a matriz obtida no item anterior e E é a matriz $2 x 1$ formada pelas coordenadas do afixo do complexo identificado pela letra $E$.

A apresentação dos números complexos contou, portanto, com a criação de contexto de ensino baseado nas relações entre conceitos matemáticos de vários blocos de conteúdos, como, por exemplo, a trigonometria, a geometria e as matrizes. No conjunto de circunstâncias que permitiu a criação do contexto não foram incluídas aplicações cotidianas e nem aspectos interdisciplinares, e tampouco foram resignificadas passagens da História da Matemática. Contextos de ensino desta natureza não excluem a exigência quanto ao uso de narrativas e nem à necessidade de traçados lineares sobre a rede conceitual. As características destes elementos diferem, todavia, daquelas mobilizadas em contextos de outros tipos, uma vez que os enredos e percursos configuram-se, principalmente, a partir da conectividade lógica existente entre procedimentos matemáticos. 
Em relação ao perigo da hiperespecialização e da redução do espectro de ampliação da teia conceitual, expressos por um trabalho pedagógico orientado unicamente sobre contextos intradisciplinares, Morin (2005) extrapola a questão e acrescenta também os perigos da redução à interdisciplinaridade. Segundo ele,

Mas a interdisciplinaridade controla tanto as disciplinas como a ONU controla as nações. Cada disciplina pretende primeiro fazer reconhecer a sua soberania territorial e, desse modo confirmar as fronteiras em vez de desmoroná-las, mesmo que algumas trocas incipientes se efetivem.

É necessário ir mais longe, e é aqui que aparece o termo transdisciplinaridade. (p. 52)

Os temas transversais, como os apontados por documentos oficiais do MEC, orientam os rumos dos trabalhos disciplinares em direção à transdisciplinaridade. Temas como Ética, Meio ambiente ou Saúde permitem que valores fundamentais ao exercício da cidadania estejam presentes nas organizações curriculares.

Contextos transdisciplinares estruturam-se sobre percursos orientados por blocos de conteúdos, não necessariamente de uma única disciplina, compostos por elementos que podem colocar-se acima das relações intra e interdisciplinares, para manifestarem sua universalidade. A transdisciplinaridade, portanto, que não exclui a contextuação, visa a ampliação dos significados associados aos objetos de estudo, apresentando-os, de certa forma com maior complexidade do que poderiam ser apresentados apenas sob o foco do olhar disciplinar ou mesmo interdisciplinar.

Contextos transdisciplinares não foram objeto de estudo deste trabalho. Todavia, julgamos que contextos de ensino com tais características permitem que vislumbremos possibilidades de extrapolar os elementos característicos da(s) disciplina(s) e projetar intervenções transformadoras nas condições que norteiam a existência dos agrupamentos sociais.

Neste capítulo analisamos exemplos de contextos de ensino para o desenvolvimento de conteúdos matemáticos de Ensino Médio, dando destaque a casos em que os conjuntos de circunstâncias características dos contextos remetem-se a aplicações cotidianas, à interdisciplinaridade, à História da Matemática e à intradisciplinaridade. Para tanto, retomamos aspectos comentados anteriormente sobre os elementos apontados por Goodman (1995) a respeito da composição de contextos e também as competências exigidas dos 
professores quanto à elaboração de narrativas apropriadas a cada situação, conforme apontado por Machado (2009).

Traçamos até aqui um percurso, iniciado com a análise da relação entre o abstrair e o concretizar na construção do conhecimento humano. Em seguida, identificamos algumas diretrizes apontadas em documentos oficiais com relação à expectativa de contextualização do ensino. Dando continuidade ao percurso, analisamos elementos para a composição de contextos, e também a postura esperada do professor na elaboração e condução de atividades voltadas para a contextualização.

Na sequência, apresentamos as conclusões que nosso estudo permitiu atingir. 


\section{CONCLUSÕES}

... os contextos, tal como as línguas, podem ser barreiras. Podem mesmo ser prisões. (Karl R. Popper)

Durante o desenvolvimento dos capítulos que compõem este trabalho buscamos responder às dívidas surgidas, principalmente, durante o exercício de nossa prática de sala de aula e na relação com outros professores. Como em qualquer conjunto planejado de ações, existiu aqui também um marco, um elemento detonador de todo o processo, que consistiu na preocupação pessoal em responder às insistentes questões dos alunos acerca da "utilidade" do conhecimento matemático que lhes era apresentado. Nessa busca, durante os estudos de mestrado, optamos por analisar a importância de desenvolver conteúdos matemáticos com base em contextos que consideramos "significativos", elaborando roteiros de trabalho a partir do que intitulamos Percursos temáticos.

Os Percursos temáticos destacam a importância do professor no planejamento de ligações entre significados de um conceito, estimulando a sequencialização para o desenvolvimento de um conjunto de conteúdos com base nas relações de proximidade que se podem detectar entre significados conceituais. Dessa forma, contrariamente a planejamentos que obedecem a estruturas baseadas em sequências hierarquizadas de conteúdos, do mais "simples" ao mais "complexo", os Percursos temáticos são, na verdade, fios condutores do trabalho que levam em conta a integração entre as diversas ideias da Matemática e ainda as múltiplas conexões entre os conteúdos matemáticos e das demais disciplinas. Entendemos que a proposta de elaboração de planejamentos didático-pedagógicos com base na estrutura metodológica ditada por Percursos temáticos formou a base que nos permitiu refletir, de modo mais amplo, sobre a importância do desenvolvimento de conteúdos matemáticos com base em contextos especialmente elaborados para situações de ensino. Chegamos, dessa maneira, a este trabalho cujas conclusões apresentamos a seguir.

Em primeira instância, queremos destacar uma das conclusões a que chegamos durante os estudos do mestrado, e que se aplica de forma equivalente à formação da base epistemológica necessária às hipóteses iniciais deste trabalho. Trata-se da concepção de que o 
conhecimento se constrói com base na metáfora da rede de significados, elaborada por Machado (2002) e por nós destacada no Capítulo 1.

Aceitando que conhecer é conhecer o significado, a próxima questão que nos propusemos a responder diz respeito à importância que as abstrações representam na aquisição dos significados dos objetos. Analisando, principalmente, os textos de Machado (2009), Tung-Sun (2000) e Rambaldi (1988), pudemos concluir que o sentido da construção conceitual parte do concreto e a ele retorna, encontrando, na volta, os objetos de estudo envoltos por antigas e novas relações de significado. O estágio intermediário, entre os dois níveis de concretude, é recheado pelas abstrações que o sujeito realiza, em função da maneira como interpreta os significados que já possui sobre o objeto. Nesse processo, de produção de abstrações e ampliação do feixe de relações de significados em que o objeto é interpretado, identificamos a importância maior da contextualização.

De acordo com algumas definições clássicas a respeito do termo, aceitamos que um contexto de ensino configura-se como um conjunto de circunstâncias que envolvem fatos, personagens, fenômenos, ideias etc., capazes de estimular relações entre significados conceituais. A elaboração de contextos de ensino torna-se eficiente, principalmente, quando os elementos desse conjunto de circunstâncias podem ser claramente associados à cultura dos sujeitos envolvidos, como comentamos no Capítulo 3.

Identificada a importância da contextualização, analisamos o modo como tal conceito se apresenta em documentos e avaliações oficiais. Pudemos, então, concluir que os documentos analisados, especialmente os Parâmetros Curriculares Nacionais (PCNs), orientam os currículos para a contextualização do ensino tomando por base, principalmente, os universos do trabalho e da cidadania, mas também, como reforçado pela proposta do Exame Nacional do Ensino Médio (ENEM), os universos da cultura, da tecnologia e da ciência.

As diretrizes expressas nos documentos analisados orientam a atividade pedagógica para a contextualização com base em temas bastante amplos, cujas características principais podem ser transpostas para situações de contexto diretamente ligadas a conteúdos disciplinares. Com este pressuposto, buscamos identificar contextos para o ensino de conteúdos matemáticos que pudessem estimular as abstrações necessárias à construção do conhecimento. Para tanto, analisamos, principalmente, os escritos de Goodman (1995), 
Popper (2009) e Machado (2009), dos quais conseguimos destacar as importantes características para a composição de contextos que comentamos em seguida.

Em relação à estrutura contextual, identificamos na obra de Goodman (1995) os seguintes cinco aspectos destacados pelo autor para a importância do que considerou "modos de fazer mundos": Composição e decomposição, Enfatização, Ordenação, Supressão e completação, e Deformação. Analisando as características desses aspectos, percebemos sua presença na composição de conhecidos contextos de ensino, como exemplificamos no Capítulo 3, e consideramos a importância a ser atribuída pelo professor a tais aspectos, no sentido de estruturar os contextos selecionados para a apresentação de conteúdos matemáticos a seus alunos.

Voltando nosso olhar para a responsabilidade do professor na composição de contextos de ensino, em função dos aspectos destacados por Goodman (1995), nos deparamos com os estudos de Machado (2009) acerca das competências esperadas de alunos e professores. Nessa etapa, além das transposições que concebemos entre a teorização desses dois estudiosos, pudemos identificar a importância das narrativas na composição de contextos de ensino, enquanto elementos capazes de transportar os significados em percursos elaborados por sobre a rede conceitual. Narrativas são, portanto, elementos que estruturam e são estruturadas pelos contextos, configurando uma combinação simbiótica, de maneira que não há como conceber contexto sem narrativa e vice-versa. Nessa perspectiva, revelou-se para nós toda a importância do professor como idealizador, roteirista e narrador de histórias capazes de agregar significados e transportá-los até os alunos.

Composto o quadro teórico a respeito da importância dos contextos de ensino, dos aspectos que podem estruturá-lo e das competências exigidas por aqueles que os elaboram, apresentamos no Capítulo 4 uma série de exemplos de contextos especialmente criados para o desenvolvimento de conteúdos matemáticos. Pudemos, então, salientar que a propalada ideia a respeito da contextualização que remete às aplicações cotidianas não é a única, e que existem outras possibilidades de composição contextual. Nesse sentido, apontamos exemplos estruturados com base na interdisciplinaridade, na história da Matemática e na intradisciplinaridade.

Chegamos, assim, a esta etapa na qual apresentamos as respostas que conseguimos à indagação inicial à respeito da contextualização do ensino da Matemática. Todavia, há ainda mais um importante elemento a acrescentar no sentido de corroborar nossas conclusões. 
Trata-se de transportar para o âmbito pedagógico a formulação de Popper (2009) acerca do mito do contexto.

Todos os contextos especialmente elaborados para ensino deste ou daquele bloco de conteúdos, de qualquer área do conhecimento, são encerrados por fronteiras invisíveis. Dentro dessas fronteiras reconhecem-se, com vigor, as relações entre significados associados aos objetos de estudo, enquanto para além delas as relações, que existem e são múltiplas, nem sempre são facilmente identificáveis. Desejando discutir aspectos de política internacional, um professor poderá, por exemplo, recorrer ao contexto histórico da Guerra Fria, no período que se iniciou no pós $2^{\mathrm{a}}$ Guerra Mundial e definhou completamente no final da década de 1980. Vários significados associados à conduta dos países envolvidos na questão decerto podem ser transportados para aspectos da política internacional de nossos dias. Haverá, entretanto, uma série de considerações específicas das crises atuais que, à primeira vista, parecerão de natureza bastante diversa das que minavam no noticiário do período de Guerra Fria. A possibilidade de compreensão acerca de tais considerações exige que sejam extirpadas as fronteiras do contexto anterior, no sentido de que as relações anteriormente construídas possam ser adaptadas às características desse novo contexto. Devemos, portanto, considerar a necessidade do contexto para a realização das abstrações e para a compreensão das inúmeras relações entre seus elementos, mas precisamos também avaliar que é parco o conhecimento que se constrói em um contexto e nele estaciona.

Um dos eixos fundamentais das competências destacado por Machado (2009) tem, em um extremo, o Âmbito e noutro, a Extrapolação. Apresenta competência em determinado assunto o sujeito que transita com desenvoltura de um a outro extremo desse eixo, no sentido que consegue identificar relações de significados conceituais entre elementos de determinado âmbito, mas que, além disso, as percebe e as extrapola para outras situações, em outros âmbitos. Entendemos que tal movimento aplica-se concretamente às relações ensinoaprendizagem de nossos alunos e, portanto, torna-se importante discorrer sobre a questão.

A apologia que se faz a respeito do ensino contextualizado justifica-se na medida em que, como assinalamos, os contextos são responsáveis, com suas relações entre elementos e circunstâncias, pelo estimulo às abstrações. Todavia, o exagero da condução dos trabalhos pedagógicos por percursos contextualizados, se permite, por um lado, que sejam explicitamente detectadas as relações entre significados internos ao contexto evita, em contrapartida, que possam ser apreendidas relações entre significados conceituais cuja 
vivência ocorre além do contexto adotado. Sobre isto, vejamos o que afirma Machado (2009), em um parágrafo por si só conclusivo:

O elogio desmesurado da contextuação dos conhecimentos escolares pode servir de base - e ordinariamente serve - para um desprestígio absolutamente equivocado da capacidade de ultrapassagem dos âmbitos efetivamente existentes, como a que ocorre quando abstraímos as circunstâncias concretas e imaginamos o que ainda não existe. (p.43)

A adoção de planejamentos pedagógicos voltados para a condução dos conteúdos por percurso de contexto único, permite que, amiúde, transpareçam situações contraditórias que revelam a necessidade, não contemplada, da abstração do que se aprende para outros âmbitos. Comentemos sobre uma dessas situações.

$\mathrm{Na}$ experiência cotidiana de professores é comum que os alunos contestem questões componentes de avaliações individuais com argumentos do tipo "nas aulas é feita uma coisa e na prova é cobrada outra”. Nos casos em que tal questionamento é pertinente, podemos inferir a responsabilidade à forma como as situações de aprendizagem foram cumpridas no período antecedente à avaliação. O provável desvio, nesse caso, se caracteriza pela condução dos conteúdos, durante as aulas, por percurso sobre contexto único, justapondo-se à cobrança na avaliação de resolução de questão elaborada em um contexto diferente, sem que o professor tenha estimulado seus alunos a extrapolarem, anteriormente, as fronteiras do contexto inicialmente adotado. Por exemplo, é como se os alunos tomassem contato unicamente com a resolução de situações-problema envolvendo a aplicação da relação parte-todo de frações representadas por retângulos divididos em partes iguais e, na avaliação, fossem convidados a expressarem com uma fração a chance de ser sorteada uma bola vermelha dentre um determinado total contido em uma caixa. Se o conceito é o mesmo, o contexto das áreas iguais compondo o todo é de natureza diferente daquele que caracteriza a relação entre o número de bolas vermelhas e a quantidade total de bolas. A diversificação dos contextos nos quais é detectada a presença da relação parte-todo é o remédio necessário para o mal aqui enunciado, qual seja, a ausência da extrapolação do significado para além dos limites de um contexto único.

Contextuação e extrapolação não são, como se poderia imaginar em alguns casos, ações opostas. Trata-se, isto sim, de ações complementares, que quando mobilizadas a serviço da compreensão conceitual, denotam a qualidade do conhecimento construído. Ou seja, citando novamente Machado (2009), 
[...]. uma pessoa somente pode revelar-se competente atuando em determinado âmbito, mas sua competência é tanto maior quanto mais é capaz de abstrair o contexto da ação e imaginar situações novas, em contextos ainda não existentes.( p. 44)

Consideremos agora a posição expressa por Popper (2009) acerca do que denominou "Mito do contexto". Segundo este filósofo da ciência, as prisões são os contextos. E aqueles que não gostam de prisões opor-se-ão ao mito do contexto (p. 98).

A crítica de Popper refere-se às posições controversas de relativistas e racionalistas, mas pode também, a nosso ver, ser adaptada para o âmbito pedagógico e estimular o equilíbrio da balança que tem a contextuação em um dos pratos e a abstração no outro.

Contextos de ensino podem ser elaborados a partir de mais de um tipo de elementos característicos, sendo o mais comum - e também o mais alardeado - aquele que se relaciona com aplicações cotidianas dos conceitos. Uma vez que o desenvolvimento de um bloco de conteúdos com base em um tipo de contexto pode e deve ser realizado também com base nas relações entre significados de elementos de outro contexto, semelhante ou não ao contexto inicial, podemos especular quanto ao grau de dificuldade da transição em alguns casos. Consideremos, por exemplo, o desenvolvimento apresentado no Capítulo 4 para o tratamento das matrizes, com base no contexto da codificação de imagens através da lógica dos bits.

A representação de dados numéricos em tabelas é a aplicação mais imediata das matrizes a situações cotidianas. Nesse contexto, não há dificuldade, no Ensino Médio, em analisar as operações entre tabelas - adição e multiplicação - dado que os elementos residentes em suas linhas e colunas apresentam significados explícitos que remetem com facilidade o aluno a planejar os procedimentos corretos para calcular o formato da tabela resultado. Tal contexto, das aplicações cotidianas, mantém, portanto, relação de proximidade com aquele em que os elementos das matrizes são vistos como códigos para formação de imagens, sendo possível conceber, sem maiores dificuldades, uma "conversa" entre o tratamento do conceito por um ou outro contexto. Quando consideramos, entretanto, contexto intramatemático para o tratamento das matrizes, como também apresentado no Capítulo 4, percebemos que o diálogo, sempre possível e necessário, exigirá, nesse caso, esforços mais concentrados por parte do professor.

O tratamento das operações entre as matrizes com base em contexto intramatemático contou com a representação de polígonos no plano cartesiano e ainda com a realização de 
translação dessas figuras. Trata-se, portanto, de contexto caracterizado pelas relações internas à própria Matemática que, como afirmamos, pode e deve ser abordado no sentido de estimular os alunos a abstraírem os limites do contexto caracterizado pelo significado das matrizes enquanto elementos codificadores de imagens no plano. Mas, o distanciamento entre significados próprios de um e de outro contexto faz com que a aproximação, nesse caso, apresente maior dificuldade do que aquela em que estão presentes o contexto das codificações de imagens e o das aplicações cotidianas em tabelas. Retomando Popper (2009), a fim de validar a necessidade de aproximação entre contextos, por mais diversos que possam ser suas características, destacamos que:

Uma discussão poderá ser também difícil, se os contextos tiverem pouco em comum. E será tanto mais fácil quanto maiores forem as sobreposições entre os contextos. ( p.70)

[...] quanto mais interessantes e difíceis tenham sido as questões levantadas tanto mais induzidos os participantes foram a pensar respostas novas, tanto mais abalados terão sido nas suas opiniões. ( p.71)

Dessa forma, evidencia-se que a proximidade entre contextos favorece a extrapolação dos limites de um a outro, mas é na dificuldade de aproximação entre contextos de naturezas díspares que residem ganhos significativos de compreensão. Justifica-se, portanto, no caso do tratamento das matrizes, como em todos os demais, que adotemos contextos com características bem diferentes para a abordagem dos conceitos. Sobre esta questão, comentemos também sobre outro par de exemplos que abordamos no Capítulo 4, referente ao desenvolvimento de conceitos da trigonometria.

Apresentamos um exemplo de contexto interdisciplinar para o tratamento das funções trigonométricas com base no fenômeno das marés, no qual evidenciamos, explicitamente, relações entre a Matemática e a Física, além de apontarmos possibilidades de relações para outras disciplinas curriculares. A riqueza das relações, todavia, não exclui a necessidade de estimular os alunos a enxergarem significados conceituais em novos e diferentes contextos. Com tal objetivo em mente, elaboramos sequência em que as funções trigonométricas são vistas sob o prisma de sua aplicação cotidiana na geração, propagação e recepção de sinais eletromagnéticos.

Poderíamos também, por outro lado, mudar um pouco o foco da questão e tratar dos conceitos da trigonometria com base em outro contexto interdisciplinar, além do composto 
com base no fenômeno das marés, voltando o estudo para as relações com a Física no que tange às características de um MHS (Movimento Harmônico Simples). De qualquer modo, ressaltamos a perspectiva apontada por Popper e também por Machado com relação à necessidade de o aluno extrapolar os conceitos para além de apenas um contexto, que poderemos estimular abordando o estudo das funções trigonométricas em contextos interdisciplinares e de aplicações cotidianas. Mas há algo que precisamos ainda considerar, que remete à nossa concepção acerca da Matemática.

A Matemática nos permite representar a realidade, e o faz por meio de seus variados sistemas de notação (algarismos, letras, tabelas, gráficos etc.). A Matemática possibilita representar, explicar, estabelecer relações, antecipar e prever resultados e ainda, compreender, explorar, interpretar a realidade e atuar sobre ela. Nestas ações denota-se a relação intrínseca entre a Matemática e a língua materna, afinal, tanto uma quanto outra nos auxiliam a construir o significado dos objetos, das ações, das relações. Ambos os sistemas desenvolvem as habilidades de interpretar, analisar, sintetizar etc. - habilidades que permitem melhor descrição do mundo em que vivemos. Há uma impregnação mútua entre Matemática e língua materna: ambas possuem funções e metas que se complementam.

Outro aspecto da relação entre Matemática e língua materna vincula a escrita como código de representação já que a linguagem matemática é dotada de símbolos, sinais e vocabulário próprios. Em relação ao trabalho com o vocabulário matemático é fundamental partir do conhecimento prévio do aluno, considerando a sua própria linguagem, a linguagem do senso comum mas sem privá-lo da aquisição da linguagem específica da Matemática. Nomes e termos do vocabulário matemático devem servir como fonte para o estabelecimento de relações entre os conceitos que estão sendo estudados e, consequentemente, para a compreensão e busca de novos significados de um conceito.

A Matemática é uma ciência construída e organizada pelo homem e, sob esse aspecto, desempenha um papel fundamental na organização do pensamento a partir do desenvolvimento de habilidades de raciocínio específicas. Estabelecer relações entre objetos, fatos e conceitos, generalizar, prever, projetar e abstrair são exemplos dessas habilidades.

A Matemática enquanto Ciência favorece a organização do pensamento, do saber, da aprendizagem. Por meio da linguagem e métodos específicos é possível formular, descrever e confirmar hipóteses de um fenômeno; criar e transformar a percepção da realidade e da ação humana, dando-lhes novos significados. De outro modo, a Matemática nessa concepção tem 
um caráter formativo, possibilitando ao aluno compreender a função das definições e demonstrações para a construção de novos conceitos, para a validação das intuições e para dar sentido às variadas técnicas aplicadas em resolução de problemas.

Os comentários dos parágrafos anteriores salientam algumas características do conhecimento matemático, por nós destacadas com grifos. Nossa intenção com estes destaques vai ao encontro da necessidade que vislumbramos de os conceitos matemáticos serem sempre abordados com base em contextos intramatemáticos, de modo que seja possível aos alunos perceberem a riqueza das relações que fazem da Matemática a ciência estruturada que é, com corpo de conceitos construído a partir não apenas da exigência das aplicações cotidianas ou das implicações interdisciplinares, mas também pela pesquisa e pelo estudo acadêmico. Além disso, julgamos necessário que os conteúdos sejam apresentados revestidos de determinada dose de rigor, no que se refere principalmente à linguagem própria da Matemática e à qualidade lógica que transparece na construção das hipóteses, demonstrações e enunciados.

Destacamos anteriormente, por mais de uma vez, o desvio que significa a condução de um planejamento por apenas um tipo de contexto, sob pena de não estimularmos os alunos a perceberem que o conhecimento que constroem não se aplica unicamente aos limites do contexto estabelecido. Neste momento, destacamos nossa convicção acerca da necessidade de que o contexto que se compõe a partir das relações internas à própria Matemática seja sempre um dos contextos adotados, ou seja, esteja sempre contemplado nos planejamentos pedagógicos, para que os alunos possam construir o edifício de seu conhecimento matemático de modo completo, com todos os elementos que apontamos nos parágrafos anteriores, e que caracterizam este conhecimento.

Popper traça um paralelo entre o aprendizado de uma nova língua e a necessidade da contextuação e da extrapolação, que julgamos interessante e recuperamos aqui com o sentido de complementar nossa proposta expressa no parágrafo anterior. Segundo este filósofo, utilizamos o conhecimento que temos sobre nossa língua de origem e o contrapomos àqueles que expressam as características da nova língua, que buscamos dominar. Nesse processo,

[...] somos forçados a olhar para a nossa própria língua de forma crítica e como um conjunto de regras e usos que podem ser algo limitados, pois são incapazes de captar completamente, ou descrever os tipos de entidades que, para outras línguas, supostamente existem. (Popper, 2009, p. 97) 
As limitações ao domínio de outra língua nos impelem a considerar nossa língua de origem como elemento de referência, tentando compreender as novas estruturas a partir daquelas que regem as que já dominamos. No entanto, não podemos ficar presos à lógica de nossa língua sob pena de não conseguirmos registrar coerentemente o conjunto de regras do novo objeto de estudo. Por exemplo, apenas em situações com alguma comicidade poderíamos traduzir "hot water" por "quente água", desprezando, dessa forma, a estrutura da língua inglesa. Somos assim forçados pelo estudo comparativo a transcender precisamente as limitações que estamos a estudar. E o interessante é que conseguimos. $O$ meio de transcender a nossa língua é a crítica. (Popper, 2009, p. 97)

É a crítica, portanto, construída pelo conjunto de abstrações que realizamos por sobre os objetos de nosso conhecimento, que permite a transcendência deste conhecimento e a ampliação de suas fronteiras. Sem dominar com qualidade a língua materna, domínio este adquirido pela vivência com os elementos contextuais que nos cercam desde os primeiros momentos de nosso aprendizado da fala e escrita, parece difícil, senão impossível, dominar algum outro idioma. Tal imagem pode aplicar-se, de modo geral, a todo o novo conhecimento que viermos a construir. Ou seja, as relações de significados conceituais que estruturam nosso conhecimento de algum objeto, estabelecidas em determinado contexto, formam a base para a construção de novas relações e para o fortalecimento das anteriores, sendo possível identificálas então, em novas circunstâncias, em novos contextos.

Aproveitamos a imagem expressa no parágrafo anterior para justificar a prevalência do desenvolvimento de conteúdos com base em contextos intramatemáticos. Ou seja, sem dominar com qualidade algumas relações internas à Matemática, ao sujeito fica difícil, senão impossível, perceber com profundidade as relações entre significados de conceitos matemáticos que se estabelecem em variados contextos.

As imagens da prisão do contexto, criada por Popper, e do eixo de competências, destacado por Machado, são emblemáticas, pois destacam, por um lado, a importância dos contextos na construção do conhecimento e, por outro, a necessidade de rompermos as fronteiras do contexto inicial e, simultaneamente, construirmos novos limites, num movimento contínuo de abstração e concretização.

É mais do que evidente que a ideia da autolibertação, de fuga da prisão do momento, pode, por seu turno, tornar-se parte de um contexto ou prisão - ou, por outras palavras, que nunca poderemos ser absolutamente livres. Mas 
podemos tornar mais ampla a nossa prisão e, pelo menos, podemos viver para lá da tacanhez de quem é viciado nos seus grilhões. (Popper, 2009, p. 100).

Por fim, em resposta à nossa preocupação inicial, concluímos que, a partir da atenção que dispensamos às relações de ensino-aprendizagem de Matemática, o conhecimento humano é construído com base nas relações estimuladas pelos conjuntos de circunstâncias que caracterizam os contextos. Concluímos também que é necessário diversificar o tipo e a qualidade dos contextos de ensino a fim de permitir que o sujeito aproxime-se de novos significados, característicos de novos contextos, possibilitando a ampliação constante do feixe de relações sobre os objetos de estudo.

Em nosso percurso nos deparamos com aspectos importantes sobre os quais o foco principal de nosso trabalho impediu que pudéssemos deter análises mais aprofundadas. No entanto, alguns desses aspectos podem vir a complementar os estudos realizados, indicando novos caminhos para pesquisa futura. Destaquemos apenas dois desses aspectos.

A metáfora construída por Polanyi (1969) para a representação do conhecimento pessoal, estruturada a partir de um iceberg poderia, a nosso ver, ser relacionada à possibilidade de contextualização dos conteúdos curriculares. A parte emersa do iceberg, nessa metáfora, corresponderia ao conhecimento que é passível de explicitação, enquanto a parte submersa, bem mais volumosa do que anterior, estaria associada à dimensão tácita do conhecimento, que sustentaria, portanto, o que é explícito e explicável.

Se aquilo que é possível de ser explicado pelo sujeito, através da utilização de algum tipo de linguagem, situa-se no campo do explícito, podendo, dessa forma, ser associado ao conhecimento disciplinar, a parte do iceberg que repousa abaixo da linha da água encontra em correspondência o universo do conhecimento tácito, sobre o qual o sujeito não possui ainda capacidades totais de explicitação, muito embora, à sua maneira, domine uma série de protorrelações conceituais. Na passagem do tácito ao explícito, ou seja, na condução das protorrelações de significados para o patamar no qual o sujeito as compreende, as codifica e as insere em ampla rede conceitual, pode situar-se a importância dos contextos de ensino. Esta é uma das hipóteses que mereceria um estudo aprofundado e que ampliaria o nível das conclusões que estabelecemos neste trabalho acerca da contextualização do ensino.

Os elementos caracterizadores dos contextos de ensino, que apontamos anteriormente para o caso da Matemática, aplicam-se de forma semelhante a outras disciplinas curriculares. Comentamos rapidamente sobre tal hipótese e acreditamos que seja possível verificá-la com 
vigor, buscando exemplos e revisitando-os à luz da teoria subsidiada por uma bibliografia que inclua as obras deste e de outros trabalhos.

Comentamos a respeito das características especiais da Matemática enquanto linguagem que codifica, representa e estabelece relações entre conceitos, no sentido de formalizar o conhecimento que se constrói. Outras disciplinas curriculares não se caracterizam da mesma forma e têm corpo de estudo que "brota" da contextualização e/ou da experimentação, como é o caso, por exemplo, da História e da Química, respectivamente. Nesses casos, talvez mais do que em outros, a construção conceitual pelo sujeito dependa diretamente do domínio da língua materna e da linguagem matemática. Se tal premissa é válida, cabe analisar se os elementos de formação contextual que apontamos e exemplificamos para a Matemática podem, de fato, aplicar-se de maneira análoga a outros campos do conhecimento, ou se é necessário efetuarem-se adaptações, exclusões e/ou inclusões.

Queremos destacar ainda mais um aspecto sobre o qual este trabalho nos fez recuperar e refletir. Trata-se de uma comparação entre o tratamento metodológico predominante no ensino da Matemática com aquele que predomina no ensino da língua materna.

Para alguns de nós, mais idosos, o ensino da língua materna esteve, nos antigos Ginásio e Colégio, estritamente ligado ao estudo das estruturas da língua. Nesta linha, os estudantes eram frequentemente confrontados com situações-problema nas quais deveriam identificar elementos nas orações (objeto, sujeito, predicativo etc.) e classificá-las (subordinadas, coordenadas etc.), sem que o próximo e decisivo passo viesse a ser dado, ou seja, sem que a interpretação do significado expresso no texto fosse analisado e debatido. Durante essa mesma época, em que a identificação dos elementos textuais não estava a serviço da construção dos significados associados ao texto, o ensino da Matemática dirigia-se, quase que única e exclusivamente, às relações internas à própria disciplina. Assim, o estudo da língua materna e o da Matemática caminhavam de forma similar para a compreensão de suas estruturas, relegando a segundo plano a extrapolação dos conceitos para âmbitos exteriores àquele organizado com base nas relações internas às próprias disciplinas.

O ensino da língua materna ocorre hoje em bases diferentes das que acabamos de descrever. Inverteu-se, de certa forma, a predominância do ensino das estruturas, de modo que os alunos são colocados frequentemente em confronto com a interpretação de significados contidos nos textos e, simultaneamente, são apresentados às características dos elementos e 
das orações. De alguma maneira, portanto, o foco do aprendizado da língua voltou-se para o significado, mas não apenas para o significado restrito à estrutura do texto, e sim para aqueles que se constroem em outros domínios, em outros contextos.

O ensino da Matemática, no entanto, com poucas exceções, não acompanhou as transformações ocorridas no ensino da língua materna. Boa parte dos cursos de formação geral ainda organiza a grade de conteúdos matemáticos a partir de um critério que prioriza o grau de dificuldade e, além disso, apresenta estes conteúdos a partir de metodologias nas quais o reconhecimento da estrutura interna à disciplina é critério único. Nesses casos, tornase efêmera a discussão sobre a necessidade de extrapolar os conceitos para além dos contextos em que são inicialmente reconhecidos.

Se a Matemática caracteriza-se também como uma linguagem, com impregnação mútua com a língua materna, como apontou Machado (2001), consideramos válido questionar: por que o ensino da Matemática não acompanhou as transformações ocorridas com o ensino da língua materna? Buscar respostas a esta questão pode, em nosso entender, fornecer novos elementos à compreensão do tema da contextualização do ensino.

Encerrando este trabalho, salientamos a esperança de que os aspectos aqui apontados a respeito da contextualização do ensino possam contribuir para a formação de um quadro teórico sobre a construção do conhecimento, e de que, de modo semelhante ao que nos ocorreu, permitam balizar a prática anterior e fornecer novos rumos para o que ainda visamos realizar. 


\section{REFERÊNCIAS BIBLIOGRÁFICAS}

ARENDT, H. A condição humana. Rio de Janeiro: Forense Universitária, 2003.

BACHELARD, G. A Epistemologia. Lisboa: Edições 70, 2010.

BARTHES, R. O rumor da língua. São Paulo: Brasiliense, 1988.

BOAVIDA, J. Educação: objectivo e subjectivo. Porto: Porto, 1998.

BODEN, M. A. Dimensões da criatividade. Porto Alegre: ArtMed, 1999.

BROUSSEAU, G. Les obstacles épistémologiques et les problèmes en Mathématiques. Recherches en didatiques des Mathématiques. v.4.2, p.146-168, 1983.

BROLEZZI, A. C. A tensão entre o discreto e o contínuo na História da Matemática e no ensino de Matemática. Tese (Doutorado). Faculdade de Educação da Universidade de São Paulo, São Paulo, 1997.

BRUNER, J. Uma nova teoria da aprendizagem. Rio de Janeiro: Bloch, 1976.

Atos de significação. Porto Alegre: Artmed, 1997.

A cultura da educação. Porto Alegre: Artmed, 2001.

CHACÓN, I. M. G. Matemática emocional. Porto Alegre: Artmed, 2003.

COLL, C. Psicologia e currículo. São Paulo: Ática, 2002.

CRUZ, M. O. Narrativas em Matemática: significado e função. In: MACHADO, N. J. e CUNHA, M. O, (org.) Linguagem, conhecimento, ação. São Paulo: Escrituras, 2003, p. $277-88$. 
DEL NERO, H. S. O sítio da mente. São Paulo: Collegium Cognitio, 1997.

DESCARTES, R. Discurso do método. São Paulo: Martin Claret, 2003.

EGAN, K. A mente educada. Rio de Janeiro: Editora Bertrand Brasil, 2002.

FEYNMAN, R. P. O que é uma lei física?. Lisboa. Editora Gradiva, 1989

GARDNER, H. Inteligências múltiplas, a teoria na prática. Porto Alegre: Artmed, 2000.

GINZBURG, C. Olhos de madeira. São Paulo: Companhia das Letras, 2001.

GOODMAN, N. Modos de fazer mundos. Lisboa: Editorial Presença. 1995.

GUSDORF, G. Professores para quêe São Paulo: Martins Fontes, 2003.

HERSH, R; DAVIS, J. P. O sonho de Descartes: o mundo segundo a Matemática. Lisboa: Difusão Cultural, 1997.

KOSIK, K. Dialética do concreto. Rio de Janeiro: Paz e Terra, 1976.

LEFEBVRE, H. Lógica formal/Lógica dialética. Rio de Janeiro: Civilização Brasileira, 1983.

LÉVY, P. A inteligência coletiva. São Paulo: Edições Loyola, 1995.

. O que é virtual. São Paulo: Editora 34, 1997.

MACHADO, N. J. Matemática e realidade. São Paulo: Cortez, 1987.

. Matemática e língua materna. São Paulo: Cortez, 2001.

. Epistemologia e didática. São Paulo: Cortez, 2002.

Educação: projetos e valores. São Paulo: Escrituras, 2002. 
Educação: competência e qualidade. São Paulo: Escrituras, 2009.

MARINA, J. A. Teoria da inteligência criadora. Lisboa: Caminho da Ciência, 1995.

MATOS, J. M.; SERRAZINA, M. L. Didáctica da Matemática. Lisboa: Universidade Aberta, 1996.

MORIN, E. Educação e complexidade. São Paulo: Cortez. 2005.

A cabeça bem feita. Rio de Janeiro: Bertrand Brasil. 2001.

Introdução ao pensamento complexo. Lisboa: Instituto Piaget, $4^{\mathrm{a}}$ ed, 2003.

MOTTA, C. D. V. B. História da Matemática na educação matemática: espelho ou pintura? Santos: Comunicar, 2006.

ORTEGA Y GASSET, J. Obras completas. Tomo II. Madrid: Alianza Editorial, 1987.

PERRENOUD, P. 10 Novas competências para ensinar. Porto Alegre: Artmed, 2000.

POLANYI, M. The tacit dimension. Gloucester/ Mass: Peter Smith, 1983.

POLYA, G. A arte de resolver problemas. Rio de Janeiro: Interciência, 2000.

POPPER, K. R. O Mito do contexto: em defesa da racionalidade da ciência. Lisboa: Edições 70, 2009.

. Conhecimento objetivo. São Paulo: EDUSP, 1975.

Textos escolhidos. Rio de Janeiro: Contraponto, 2010.

POZO, J. I. A solução de problemas. Porto Alegre: Artmed, 1998.

RADFORD, L. Sobre Psicologia, Epistemologia Histórica e o ensino da Matemática: rumo a uma história sócio-cultural da Matemática. For the learning of Mathematics. (1997). 
RAMBALDI, E. Abstrato/Concreto in Enciclopédia Einaudi. Vol.10. Lisboa: Imprensa nacional - Casa da Moeda, 1988.

RICOEUR, P. Teoria da interpretação: o discurso e o excesso de significação. Lisboa: Edições 70, 2009.

SAGAN, C. O mundo assombrado pelos demônios. São Paulo: Companhia das Letras, 1997.

SCHAFF, A. História e verdade. São Paulo: Martins Fontes, 1987.

SCHENBERG, M. Pensando a Física. São Paulo. Editora Brasiliense, 1984.

SCHOENFELD, A. H. Mathematical problem solving. New York, NJ: Academic Press, 1983.

SILVA, C. M. S. A História da Matemática e os cursos de formação de professores. In: Cury, Helena Noronha (org.). Formação de professores de Matemática: uma visão multifacetada. Porto Alegre: EDIPUCRS, 2001.

SPINELLI, W. Aprendizagem matemática em contextos significativos: objetos virtuais e percursos temáticos. Dissertação (Mestrado). Faculdade de Educação da Universidade de São Paulo, São Paulo, 1995.

STEWART, I. Cartas a uma jovem matemática. Lisboa. Relógio D’água, 2006.

TUNG-SUN, C. A teoria do conhecimento de um filósofo chinês. In: CAMPOS, H. Ideograma: lógica, poesia, linguagem. São Paulo: EDUSP, 2000.

VYGOTSKKY, L. S.; LURIA, A. R. e LEONTIEV, A. N. Linguagem, desenvolvimento e aprendizagem. São Paulo: Ícone - EDUSP, 1988.

ZYLBERSZTAJN, A. Resolução de problemas: uma perspectiva kuhniana. In: Atas do VI EPEF. Florianópolis, 1998. 